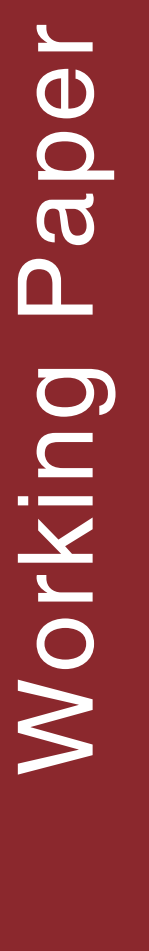

Ramya Sehmi, Cheikh Mbow, Sari Pitkanen, Helen Cross, Nicholas Berry, Mike Riddell, Janne Heiskanen, Ermias Aynekulu

\title{
Bioclimate
}




\section{Replicable tools and frameworks for biocarbon development in West Africa}

Ramya Sehmi, Cheikh Mbow, Sari Pitkanen, Helen Cross, Nicholas Berry, Mike

Riddell, Janne Heiskanen, Ermias Aynekulu 
Correct citation: Sehmi R, Mbow C, Pitkanen S, Cross H, Berry N, Riddell M, Heiskanen J, Aynekulu E. 2016. Replicable tools and frameworks for bio-carbon developments in West Africa. ICRAF Working paper No. 237. Nairobi, World Agroforestry Centre. DOI: http://dx.doi.org/10.5716/WP16138.PDF.

Titles in the working paper Series aim to disseminate interim results on agroforestry research and practices and stimulate feedback from the scientific community. Other publication series from the World Agroforestry Centre include: Technical Manuals, Occasional Papers and the Trees for Change series.

Published by the World Agroforestry Centre

United Nations Avenue

PO BOX 30677, GPO 00100

Nairobi, Kenya

Tel: +254(0) 20722 4000, via USA +1650 8336645

Fax: Tel: +254(0) 20722 4001, via USA +1650 8336646

Email: worldagroforestry@cgiar.org

Working Paper No. 237

The views expressed in this publication are those of the authors and not necessarily those of the World Agroforestry Centre.

Articles appearing in the working paper series may be quoted or reproduced without charge, provided their source is acknowledged. 


\section{About the authors}

\section{Ramya Sehmi}

Ramya Sehmi holds a BSc in Environmental Sciences from the University of Nottingham. She worked as a research assistant under the Biocarbon and Rural Development (BIODEV) project at the World Agroforestry Centre.

\section{Cheikh Mbow}

Dr Cheikh Mbow served as a Senior Scientist on Climate Change and Development at the World Agroforestry Centre from 2012 to 2016. He is an Adjunct Professor at Michigan State University's Department of Forestry and lead author of the Agriculture, Forestry and Other Land Use (AFOLU) chapter in IPCC's Fifth Assessment Report, and the Intergovernmental Science-Policy Platform on Biodiversity and Ecosystem Services (IPBES). He is currently the Executive Director of START International in Washington-DC, USA.

\section{Sari Pitkänen}

Dr Sari Pitkänen received her PhD in forestry in 1998. She works at the University of Eastern Finland, School of Forest Sciences and is the coordinator of UEF's bioeconomy programme. She is also the Secretary General of the International Partnership for Forestry Education (IPFE). Pitkänen has also served as a Planning Officer, Research Scientist and Research Officer at the University of Joensuu, and authored several scientific papers.

\section{Helen Cross}

Dr Helen Cross is a human ecologist who specializes in livelihoods research. She holds a PhD in Anthropology from University College London and leads the marine turtle conservation programme on Bastimentos Island, Panama, for the Endangered Wildlife Trust, UK.

\section{Nicholas Berry}

Dr Nicholas Berry's expertise is in participatory project design, and the development of monitoring approaches linked to adaptive management and performance-based finance. He has over 10 years' experience in community-based natural resource management projects in Africa and Asia. Berry has an MRes in Environmental Management, a PhD in Tropical Forest Ecology, and is the former Chair of the Technical Advisory Committee of the Plan Vivo Foundation.

\section{Mike Riddell}

Dr Mike Riddell's background is in political ecology and inter-disciplinary research. His expertise is in the application of participatory methods and processes to understand the links between natural resource-based livelihoods and environmental change, livelihood monitoring, and the participatory design of benefit-sharing arrangements. He holds an MSc in Biodiversity Conservation and Management and a DPhil from Oxford University's Centre for the Environment.

\section{Janne Heiskanen}

Dr Janne Heiskanen is a researcher in the Department of Geosciences and Geography, University of Helsinki, Finland. His main research interests include measurement and 
mapping forest and vegetation biophysical attributes using field inventories and different types of remote sensing data. He holds a PhD in Geography.

\section{Ermias Aynekulu}

Dr Ermias Aynekulu is a land health scientist at the World Agroforestry Centre. His research work broadly focuses on land health surveillance which aims at measuring and monitoring land health constraints to provide sustainable ecosystem services and targeting interventions to improve agro-ecosystem health and human wellbeing. He leads land health projects in Africa and co-ordinates UNCCD activities within ICRAF. 


\section{Table of Contents}

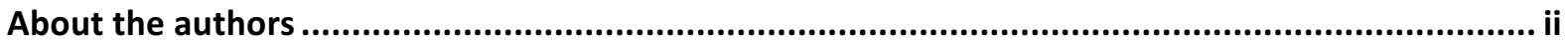

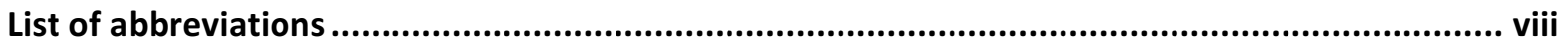

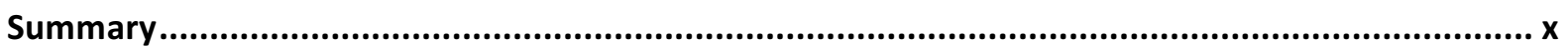

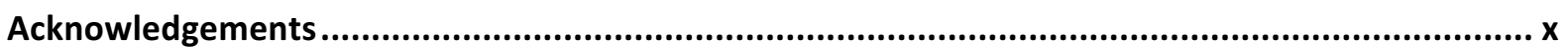

Key terms

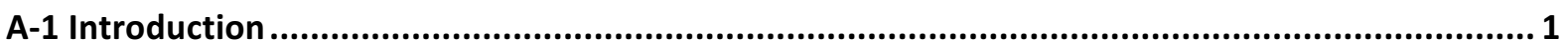

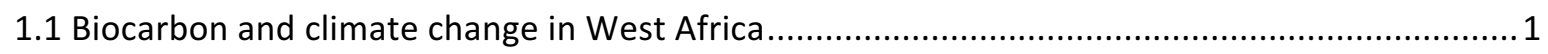

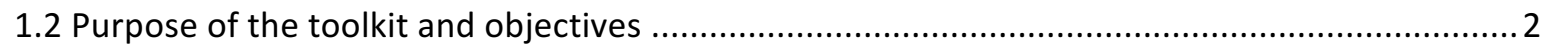

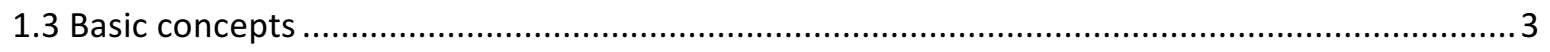

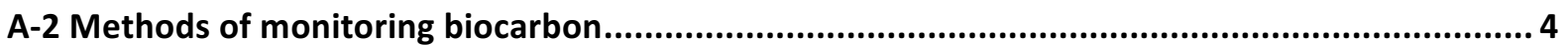

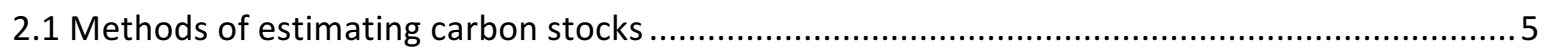

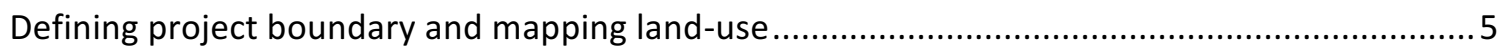

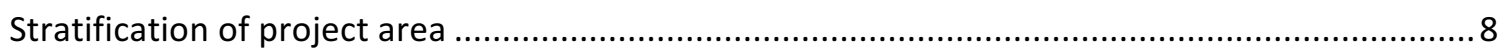

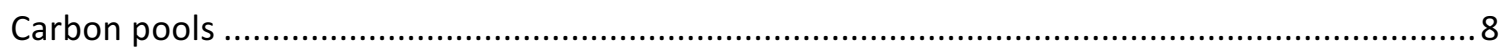

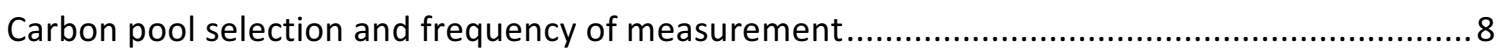

Definition of measurement parameters and sampling methods: shape and number of plots .... 10

Sampling methods: shape, area and number of plots ............................................................. 10

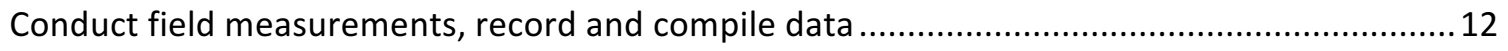

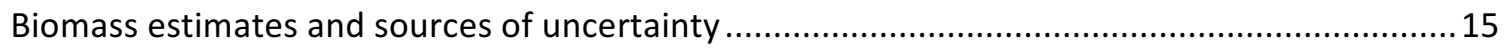

2.2 Carbon dioxide emission reduction through efficient wood energy (improved stoves) ............ 18

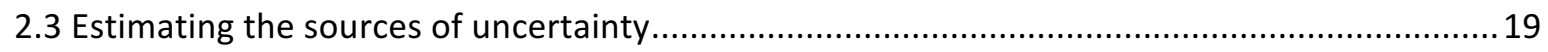

B-1/Development of fruit and vegetable trees for emission reduction and carbon sequestration. 20

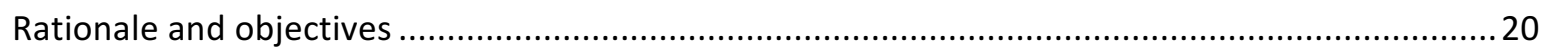

Data and information requirements for carbon sequestration in fruit and vegetable trees ...........21

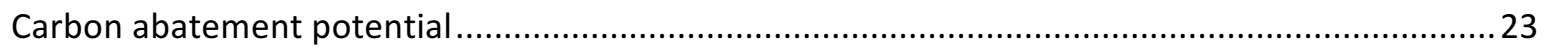

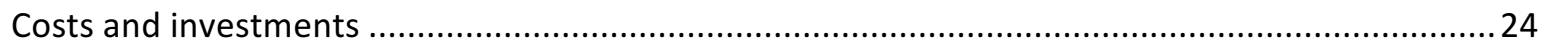

Environmental and socioeconomic benefits of fruit and vegetable trees ...................................... 25

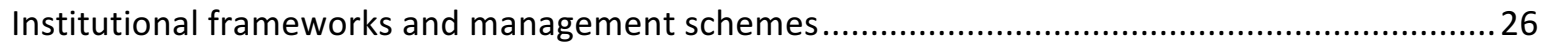

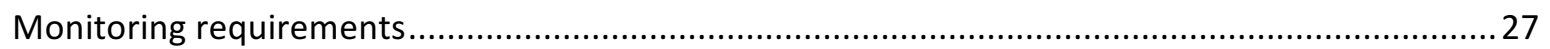

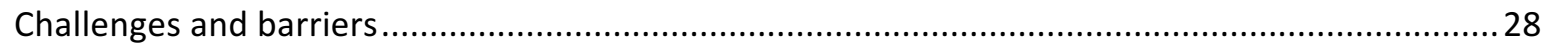

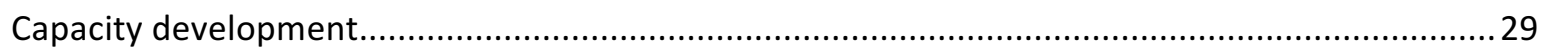


References.

B-2/Protection of standing biomass for emission reduction and carbon sequestration

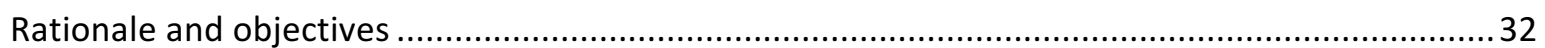

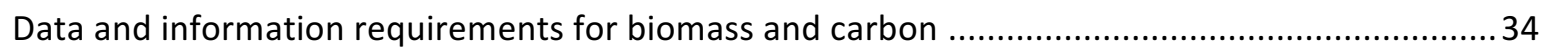

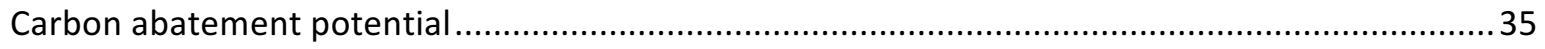

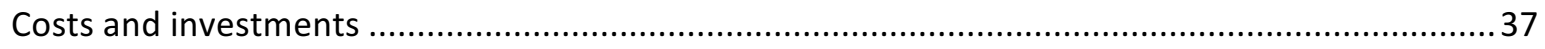

Environmental and socioeconomic benefits of conserving standing biomass .............................38

Institutional frameworks and management schemes .................................................. 40

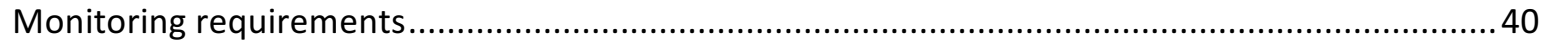

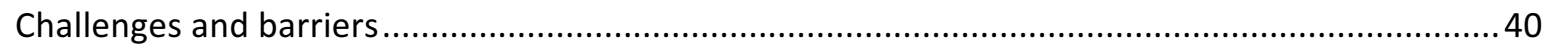

Capacity development......................................................................................... 41

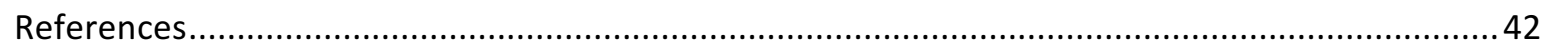

B-3/Nitrogen-fixing trees and soil fertilization ............................................................ 44

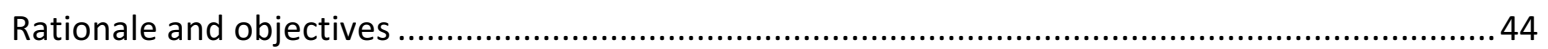

Data and information requirements for carbon sequestration by nitrogen-fixing trees and soil

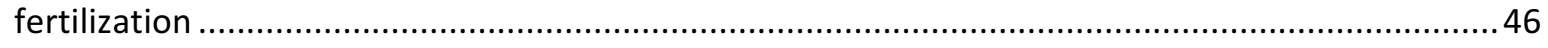

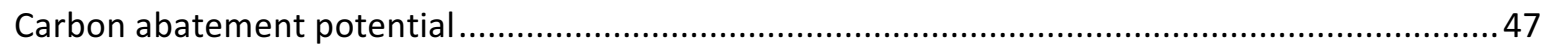

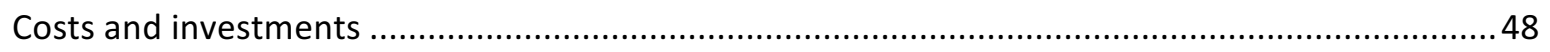

Environmental and socioeconomic benefits of nitrogen-fixing trees and fertilization ..................49

Institutional frameworks and management schemes .................................................... 49

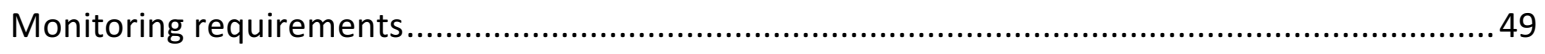

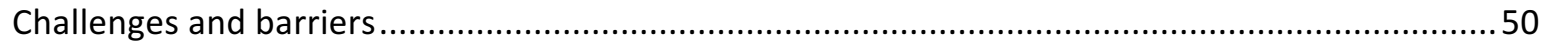

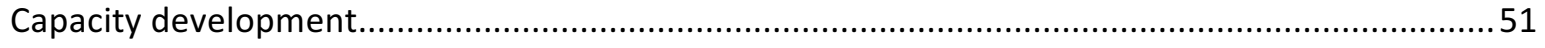

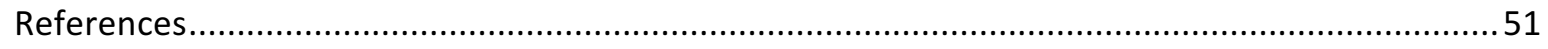

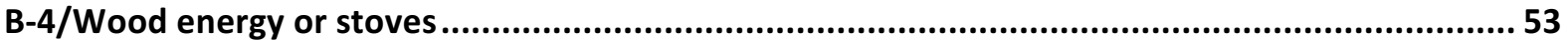

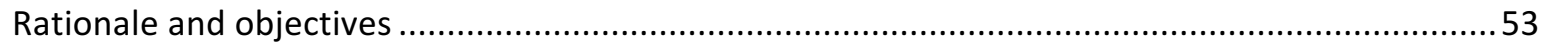

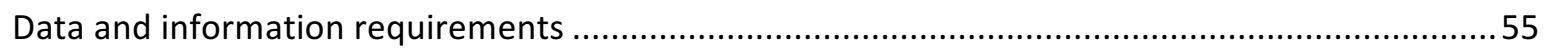

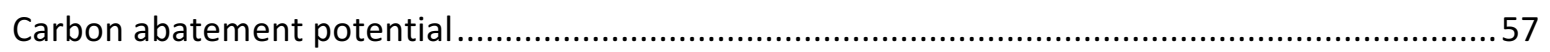

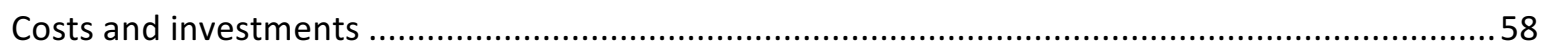

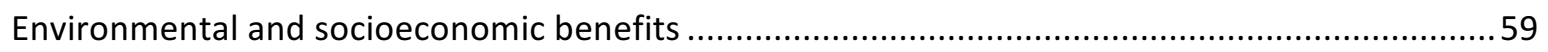

Institutional framework and management schemes ................................................. 59

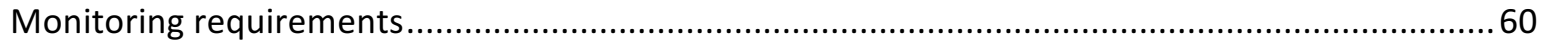

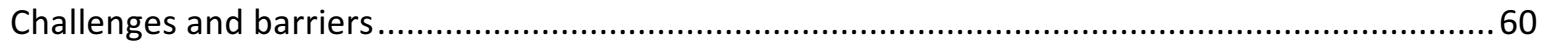

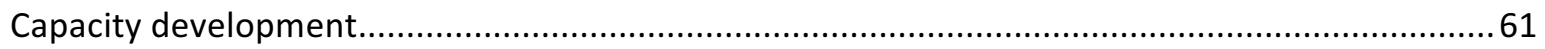


Sustainable energy wood management

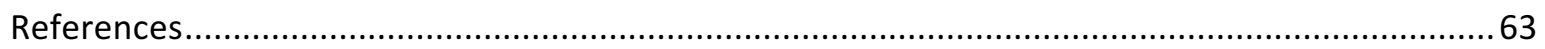

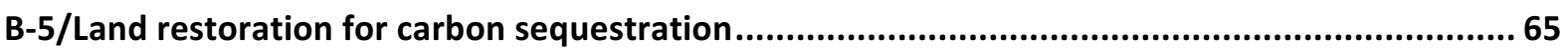

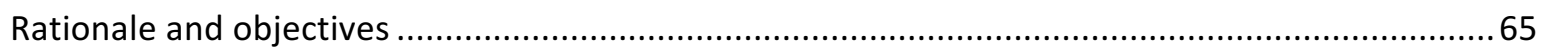

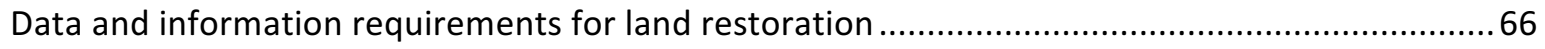

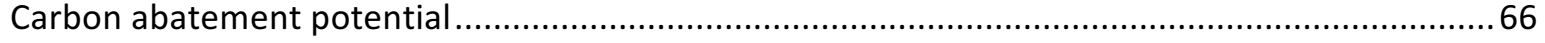

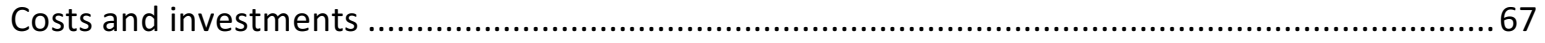

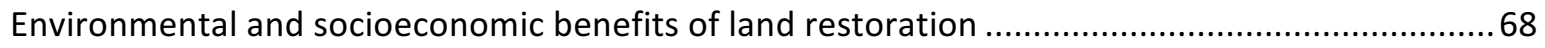

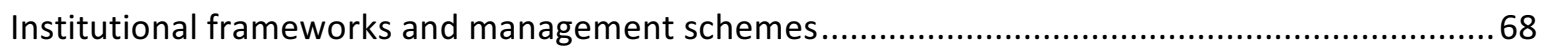

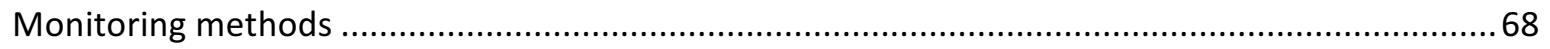

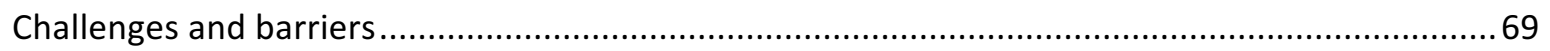

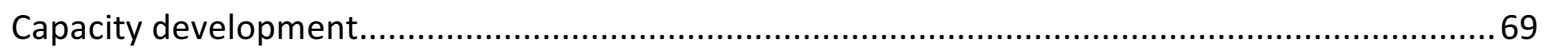

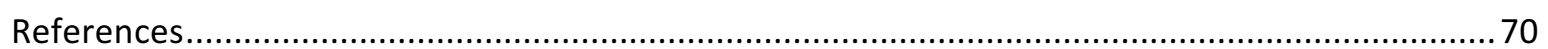

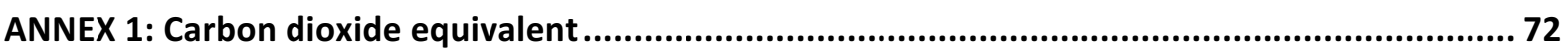

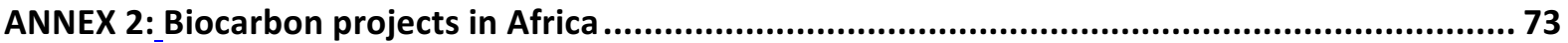




\section{List of abbreviations}

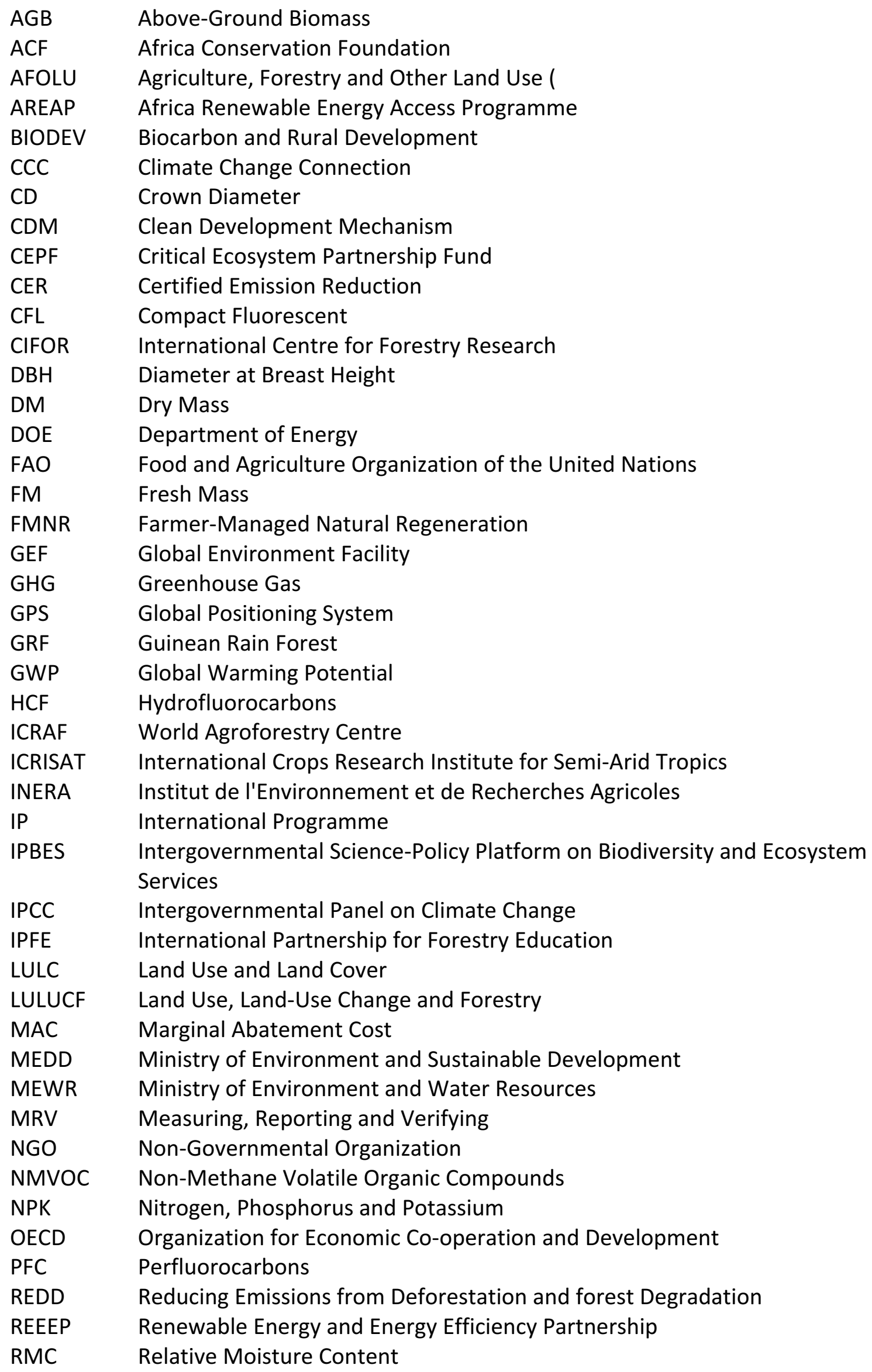


RWEDP Regional Wood Energy Development Programme

SOCSOM Sequestration of Carbon in Soil Organic Matter

STEWARD Sustainable and Thriving Environments for West African Region Development

UEF University of Eastern Finland

UK United Kingdom

UN United Nations

UNCCD United Nations Convention to Combat Desertification

UNEP United Nations Environment Programme

UNFCCC United Nations Framework Convention on Climate Change

USA United States of America

USAID United States Agency for International Development

USDA United States Department of Agriculture

USFS United States Forest Service

UTM Universal Transverse Mercator

VCA Value Chain Analysis

WP Work Package 


\section{Summary}

This working paper is intended to help countries in West Africa, and local communities and farmers to adopt climate-smart land management practices that enhance carbon sequestration. Abating greenhouse gas emission from land use should not, in the African context, limit a community's development. Hence, promoting a High Value Biocarbon community of practice should first address the livelihoods of inhabitants through increased socioeconomic development opportunities. The document highlights the importance of interventions like agroforestry in attaining good quality and quantity of products by highlighting the significance of growing fruit and vegetable trees, nitrogen-fixing trees against heavy fertilizer usage, protection of standing biomass, utilization of improved wood energy stoves and land restoration. The substantial amount of information and data required to execute each of the projects are given in detail in this working paper, together with the socioeconomic and environmental benefits, costs incurred, monitoring requirements, proposed management schemes and capacity building. The rates of success of the projects can be measured by conducting carbon inventories, estimating the amount of carbon dioxide emissions released, and carrying out surveys among locals to ascertain the quality and quantity of produce and market values. The challenges and barriers experienced in implementing biocarbon development projects can be addressed by increasing the number of training workshops offered on conducting carbon inventories, bridging the gaps in research and development, increasing access to capital and improving infrastructure development. It is fundamental to ensure progress in these statures to encourage further sustainable farming techniques for the benefit of the environment, society and the economy.

\section{Acknowledgements}

This document is part of a series of publications from WP2 of the BIODEV project funded by the Government of Finland. We are thankful to the community of Cassou in Burkina Faso and the INERA scientists who facilitated the work in the field. Thanks to Dr. Jerome Tondoh for the overall coordination. Our warm thanks to Susan Onyango for the valuable reviews. 


\section{Key terms ${ }^{1}$}

Agroforestry - In simple terms, agroforestry means growing trees on farms. This can include the development of fertilizer trees, fruit trees, fodder trees, medicinal trees and timber and fuelwood trees. Many of these trees are multipurpose, providing a range of benefits.

Biomass - Organic material derived from living or recently living organisms, often referring to plant materials. Biomass is also considered as a source of renewable energy.

Biocarbon and Rural Development project (BIODEV) - An initiative to achieve developmental and environmental benefits that can be accrued from building biological or natural carbon through improved agroforestry and forestry management and tree planting. Carbon - One of the most abundant elements on Earth and in the atmosphere. Carbon is the chemical basis for all known life. It is absorbed and emitted in various forms throughout the carbon cycle, but the amount is effectively constant. Carbon projects measure the carbon dioxide sequestrated by trees.

Carbon credit - A trade-able unit or certificate which represents one metric ton of carbon. A carbon credit or carbon offset can be sold as a reduction in emissions of carbon dioxide and other greenhouse gases made in order to compensate for, or to offset an emission made elsewhere.

Carbon dioxide $\left(\mathrm{CO}_{2}\right)$ - Naturally occurring greenhouse gas and a by-product of burning fossil fuels or biomass, or land-use changes and industrial processes. It is the principal anthropogenic greenhouse gas that affects the Earth's radiative balance leading to global warming.

Carbon emissions - In the carbon cycle, carbon dioxide is absorbed by plants and may be reemitted as carbon dioxide by organisms which consume the biomass accumulated by plants. The term is often associated with the enhanced emissions produced by human activities through burning of fossil fuels. Carbon emissions from different activities such as flying, driving and heating or cooling homes can now be accurately calculated. These calculations are used to measure the amount of carbon credits required to offset such emissions.

Carbon markets - There are two types of carbon markets namely compliance and voluntary. The compliance markets are prescribed by the United Nations Framework Convention on Climate Change and realized through Clean Development Mechanism Projects Certified Emission Reduction (CER) permits, which are sold and traded between nations. Voluntary markets, on the other hand, are less centralized and include transactions between individuals and businesses, and private or not-for-profit companies which buy and sell carbon credits to offset the carbon emissions they generate.

Carbon sequestration - This is the direct removal of carbon dioxide from the atmosphere through land-use change, afforestation, reforestation and/or increases in soil carbon.

Carbon sink or carbon pool - A system that can store and/or accumulate carbon e.g. aboveground biomass (trees and vegetation), litter, dead wood and soil organic carbon.

Carbon standard - Normally associated with the voluntary carbon market, a carbon standard is a set of quality standards and procedures to ensure a rigorous and transparent carbon forestry project. Each standard provides guidelines for validating, measuring, and monitoring carbon offset projects.

Forest degradation - The reduction of a forests productivity or ecological function through selective logging although land use/cover remains as forest. In contrast to deforestation, this is often a gradual process enhanced by changes in local micro-climates and forest fires.

\footnotetext{
1 Sources: Alforte et al. 2014, IPCC 2013, ICRAF 2016
} 
Greenhouse gas - Gases concentrated in the atmosphere which enhances the warming effect, effectively creating a blanket around the earth. They include carbon dioxide $\left(\mathrm{CO}_{2}\right)$, carbon monoxide $(\mathrm{CO})$, nitrous oxide $\left(\mathrm{N}_{2} \mathrm{O}\right)$, oxides of nitrogen $\left(\mathrm{NO}_{\mathrm{x}}\right)$, methane $\left(\mathrm{CH}_{4}\right)$, and non-methane volatile organic compounds (NMVOCs). The Kyoto Protocol also addresses hydrofluorocarbons (HCFs), perfluorocarbons (PFCs), and sulphur hexafluoride ( $\left.\mathrm{SF}_{6}\right)$. Land use, land-use change and forestry (LULUCF) - The United Nations Framework Convention on Climate Change defines this as, 'A greenhouse gas inventory sector that covers emissions and removal of greenhouse gases resulting from direct human-induced land use, land-use change and forestry activities.' Emissions from LULUCF are estimated to represent up to $20 \%$ of the global emissions annually.

Mitigation - The reduction and prevention of greenhouse gas emissions and enhancement of existing sinks.

Nitrogen fixation - This is a process by which nitrogen $\left(\mathrm{N}_{2}\right)$ in the atmosphere is converted into ammonia $\left(\mathrm{NH}_{3}\right)$ and made available to plants.

Permanence - A key concept in carbon forestry projects. Ensuring 'permanence' of the claimed carbon sequestrated through procedures and practices which guarantee that the trees planted or protected remain so. In practice, this is difficult to guarantee and losses due to disease, fires and even neglect are a reality. Therefore, more carbon standards require the project to set aside a 'buffer' in case of loss of trees and the carbon they store.

Remote sensing - Is the art and science of making measurements of the earth using sensors on airplanes or satellites.

Technical specifications - A specified land-use activity, including the methodology used to quantify carbon sequestrated, assessment of risks and leakage, the management and monitoring system to be adopted, and descriptions of likely ecosystem services, including but not limited to carbon. Many technical specifications have already been developed so there may be no need to develop ones for your specific project. 


\section{A-1 Introduction}

\subsection{Biocarbon and climate change in West Africa}

Loss of tree cover is a major contributor of greenhouse gas emissions in sub-Saharan Africa. The sustainable management of forests, including tree crop systems, is vital to the success of community climate change adaptation needs while supporting global climate change mitigation efforts. Investments in improved woody vegetation management offer the most significant carbon sequestration possibilities in rural landscapes. More importantly, they also have positive effects on other environmental services (e.g., water flows and biodiversity), energy provision, agricultural productivity and income (Sinare and Gordon 2014). In addition to benefits through mitigation, agroforestry and forests contribute to communities' ability to adapt to climate change (Mbow et al. 2014, FAO, 2010). Trees on farms increase the resilience and productivity of agricultural systems, thus increasing the adaptive capacity of smallholder farmers.

A broad-based carbon enrichment strategy at landscape level will also contribute to increased biomass for energy, reducing pressure on forests that are critical for environmental services. It also enriches soils so that they are more productive and capable of uplifting agricultural production and income (Lal 2004, Shibu, 2009). Products from forest and woodland resources are likewise known to provide local communities with muchneeded resources and income, especially during periods of drought and other climaterelated disasters. Products of several species managed by farmers have sale values in the tens of millions of dollars each year. Additionally, fuelwood from trees accounts for over $9 \%$ of total primary energy globally (FAO 2016). In Africa, around $92 \%$ of wood removals from forest and woodland are for fuel (Amous 1997).

Stock and flux are two important concepts which are subsequently linked; increase in stock indicates that the ecosystem absorbs carbon. This fact comes from the law of conservation of mass. For instance, if carbon stock is growing, it means that there is more carbon entering than going out. In other words, the net balance of flux is an inbound flux. It means that if $\mathrm{CO}_{2}$ is removed from the atmosphere, the atmospheric concentration of greenhouse gases is decreased and climate change is reduced. In that case, the process is called carbon fixation, absorption or removal, and the ecosystem is called a carbon sink. Conversely, if the stock decreases (for instance in a decaying or burning forest), an outbound flux will increase atmospheric greenhouse gas concentrations and increase climate change. The process is known as carbon emission, and the ecosystem is called a carbon source.

Both forested and agricultural landscapes provide a variety of environmental services that are very sensitive to human pressure. Lowering the rates of deforestation or enhancing the carbon stocks in an ecosystem results in mitigation. In particular, mitigation benefits come from improved management actions leading to lower emissions or in increased removal of carbon from the atmosphere, thus lowering the $\mathrm{CO}_{2}$ in the atmosphere. Concurrently, these same landscapes can provide benefits that increase resiliency of communities. Such adaptation benefits include improved water resources, biodiversity and varied economic 
opportunities through agricultural products and services, timber, non-timber products and cultural values. Those services and landscapes are themselves vulnerable to climate variability and change, for example, due to higher frequency of forest fires and other forms of human or animal pressures. Thus, forest or agricultural management itself needs to be adapted to become more resilient.

In Africa the potential to bundle mitigation and adaptation through sustainable land management is demonstrated, but communities lack the technical skills and knowledge to plan and implement climate-smart solutions. Currently, technical capacities expressed through various agreements are weak in most countries. Improved capacity is therefore a requirement for biocarbon approaches in the continent. This toolkit was developed to fill the gap and nurture opportunities through mainstreamed knowledge to various groups of practitioners.

The key message in this publication is that the same management action can both provide mitigation and adaptation benefits. Mitigation benefits are realized through reduced emissions from deforestation and increased carbon sinks from planted trees, while adaptation benefits come through the greater climate resilience of local communities from continued regulation and provision of ecosystem services.

It is important therefore that strategies to improve agroforestry, tree and forest management emphasize their contribution towards development and wellbeing. Those benefits generally offer greater private financial rewards than do the benefits from environmental services, and thus they tend to drive the incentives for investment to a greater degree (Bugayong 2003).

Building carbon in ecosystem reservoirs through improved agroforestry and forest management and tree planting is referred to as biocarbon development in this paper. The Biocarbon and Rural Development (BIODEV) project by ICRAF uses forestry, agroforestry and trees to derive a broad range of development and environmental outcomes (i.e., not just for carbon); which is referred to as high-value biocarbon development. Approaches to sustainable rural development are critical in the light of climate change and the increasing importance of adaptation and mitigation.

\subsection{Purpose of the toolkit and objectives}

There is a variety of cost-effective mitigation options available that are based on forest resource management. These options offer opportunities for many African countries to both contribute to climate change mitigation, and to improve adaptive capacities of poor communities. In this context, the term 'biocarbon' is defined as the broad sector that includes renewable energy derived from biomass and organic wastes, as well as the carbon sinks (trees, vegetation, soil and peat) found in agricultural, forest and other terrestrial ecosystems. A set of transformative options that are widely applicable in rural areas of West Africa to contribute to the prevention of emissions by maintaining and enhancing current biocarbon sinks, and contribute to the removal of carbon from the atmosphere through the establishment of new biocarbon sinks were selected.

The sectors described in this toolkit include:

1) Development of fruit and vegetable trees 
2) Protection of standing biomass

3) Development of nitrogen-fixing trees and soil fertilization

4) Improved wood energy/stoves

5) Land restoration for carbon sequestration.

\subsection{Basic concepts}

The carbon cycle is a biogeochemical cycle where carbon is exchanged among the components of the Earth, namely atmosphere, biosphere, hydrosphere, pedosphere and geosphere.

Carbon dioxide is present in reservoirs where it can be stored or released (e.g., in soil and vegetation) called carbon pools. These carbon pools either store the carbon to form a carbon sink, or release the carbon dioxide to become a carbon source. The process by which carbon dioxide is removed from the atmosphere for storage by a subsequent carbon pool is referred to as carbon sequestration. Carbon emission is the removal of biocarbon from carbon sinks into the atmosphere. Additionally, a carbon flux is defined as the rate of exchange between carbon pools.

\section{Carbon pool Carbon pool}

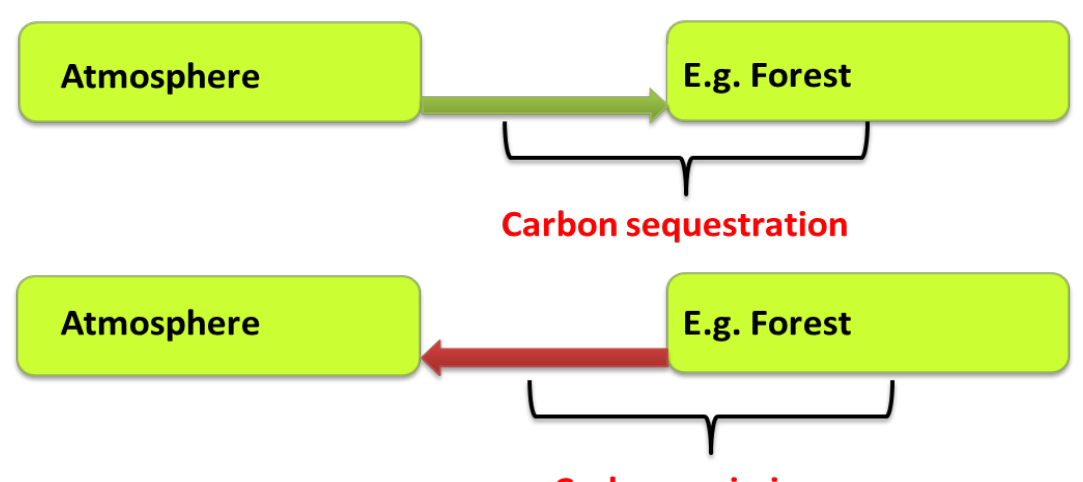

Carbon emission

Figure 1.1: Terms used in the exchange of carbon dioxide between carbon pools

Remote sensing technologies combined with ground measurements play a key role in measuring and monitoring the carbon budget. 


\section{A-2 Methods of monitoring biocarbon}

To avoid repetition in subsequent sections of this toolkit (section $B-X$ ), the general methods of monitoring biocarbon are discussed here. Any additional details are then covered in specific sections.

There are three techniques that can be used to measure biomass and carbon in forests (Ravindranath and Ostwald 2008).

a) Field measurements

b) Remote sensing

c) Allometric modelling

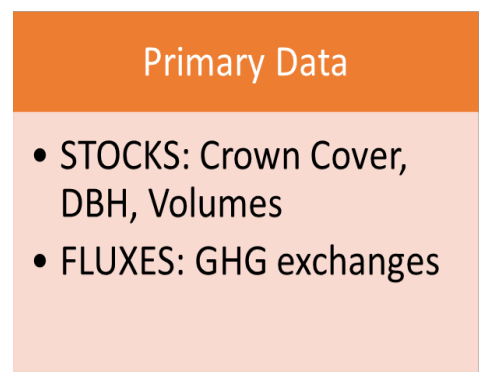

\section{Biomass estimation}

- Direct Biomass harvesting

- Statistical regressions

- Expansion Factors

\section{- Direct parametric} measurements (Crown cover)

- Indirect Biomass assessment (Vegetation Indices)

\section{- Above and Below Ground biomass - Biomass Harvesting - Volume estimates}

- Remote sensing - Aerial Photography

- Forest inventories - Destructive sampling

Assessing stocks for different pools

\section{Carbon dynamics}

- Stock changes

- Fluxes Changes

Figure 2.1: A summarized figure of the significant information and steps required for the implementation of a successful carbon inventory with measurements involved and subsequent techniques used (Source: Ravindranath and Ostwald 2008).

The most common field measurements of trees to determine carbon stock include the stem diameter at breast height (DBH), tree height and crown diameter. These biometric measurements are essential as they can be used to estimate converted tree biomass using allometric models (Brown 1997, Nair et al. 2010). Furthermore, carbon content can be derived from biomass as approximately $50 \%$ of biomass is carbon.

The growth of fruit and vegetable trees, nitrogen-fixing trees and fertilizer, conservation of standing biomass, use of wood energy or efficient stoves and land restoration all have substantial effects on the above-ground biomass of the consequential ecosystems. Therefore, determining the above-ground biomass of trees and monitoring changes in it is very relevant. 


\subsection{Methods of estimating carbon stocks}

Trees are important features in farming landscapes in West Africa. Yet estimating the carbon potential of numerous agroforest systems has been limited. A good way to visualize a stock of carbon is to think of the biomass stored in the ecosystem. Almost $50 \%$ of the dry biomass is carbon. If the dry biomass of a tree is two tonnes, then it contains around one tonne of carbon ( $C=$ biomass $X 0.47$ ).

Mapping of project area and creating project boundary

Identification of project site and boundary

\section{Stratification of project area}

Identification of homogeneous

areas

Select carbon pools and

frequency of measurement

Identify parameters, sampling

Prepare the sampling method for methods: shape and number of plots

each pool selected

Plan for data collection

$\longrightarrow$

$\rightarrow$ Conduct field measurements, record and compile data Analyse data and estimate uncertainty

Reporting

Figure 2.2: Simplified steps indicating the process of estimating carbon stocks of fruit and vegetable trees or agroforestry systems in a defined project area (Source: Ravindranath and Ostwald 2008)

\section{Defining project boundary and mapping land-use}

Identifying the project boundary is the first crucial step to obtaining a carbon inventory of the specified land-use category. In general, there are two approaches of developing project boundaries (Ravindranath and Ostwald 2007):

a) Ground-based methods

b) Remote sensing

The method used to form a project boundary is highly dependent on the status of land, the vegetation and scale of the project. For example, a large-scale project would benefit most from the use of remote sensing. 


\section{Ground-based methods}

These methods are useful for small-scale projects and include physical measurements or using GPS coordinates to form a project boundary.

Table 2.1: Methods and materials required for defining project boundaries

\begin{tabular}{|c|c|c|c|}
\hline Methods & Physical measurements & GPS measurements & Remote sensing and GIS \\
\hline $\begin{array}{l}\text { Materials } \\
\text { required }\end{array}$ & $\begin{array}{l}\text { Compass, measuring tape } \\
\text { or chains, permanent } \\
\text { marker, clinometer (if the } \\
\text { site is sloped), notebook, } \\
\text { survey pegs and hammer. }\end{array}$ & $\begin{array}{l}\text { GPS, notebook, tagging } \\
\text { device and local maps for } \\
\text { latitude and longitude } \\
\text { coordinates and a } \\
\text { compass. }\end{array}$ & $\begin{array}{l}\text { Multispectral high to } \\
\text { medium resolution } \\
\text { satellite image (e.g. } \\
\text { LANDSAT, ASTER, SPOT, } \\
\text { GEOEYE, RAPIDEYE, } \\
\text { QUICKBIRD etc.) and GIS } \\
\text { software. }\end{array}$ \\
\hline $\begin{array}{l}\text { Picture } \\
\text { examples }\end{array}$ & $\begin{array}{l}\text { Planted Forest Inventory in } \\
\text { Mbao (Senegal) }\end{array}$ & $\begin{array}{l}\text { Delineated Strate in Welor } \\
\text { (Senegal) }\end{array}$ & $\begin{array}{l}\text { Quickbird image of the } \\
\text { Ferlo (Senegal) }\end{array}$ \\
\hline
\end{tabular}

Ravindranath and Ostwald 2008

Direct measurements

A compass, measuring tapes or chains can be used to analyse the area and mark the positions using pegs, depending on if the land is level.

GPS measurements

Select the coordinate system and unit required and enter them into the GPS for recording and tracking the project boundary. The GPS should properly be calibrated for precision in data acquisition. Using metric units in map coordinates such as UTM-based projection will help in translation of field coordinates-based maps. Landmarks should be properly tagged using metal clips or any device that can be used for marking and make notes of error estimates given by the GPS (Ravindranath and Ostwald 2007). A compass would be beneficial as vegetation may be dense in some areas and this interferes with the transmission signals from the satellites. 


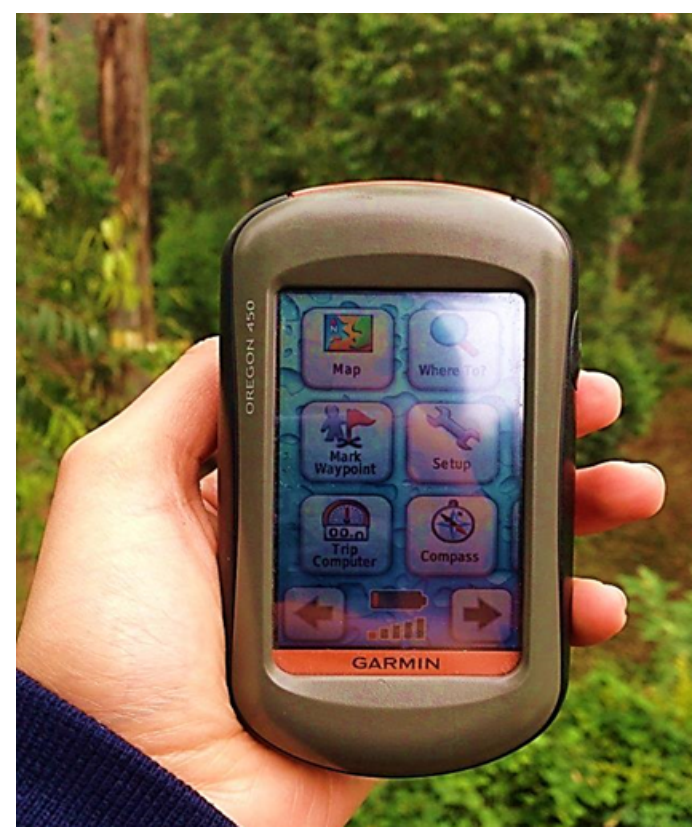

Figure 2.3: Example of a handheld GPS (Photo by Ramya Sehmi)

\section{Remote sensing and GIS}

Remote sensing comprises using sensors mounted on satellites on aircrafts and involves the use of passive and active satellite methods and instruments, including aerial photography. Remote sensing is widely used for large-scale projects. This method involves the detection and measurement of land objects using satellite imageries (e.g. LANDSAT, MODIS, ASTER, SPOT) and aerial photographs through visual interpretation or classification methods (Graham 1999). Examples of remote sensing software include ENVI, ERDAS, GRASS, etc.
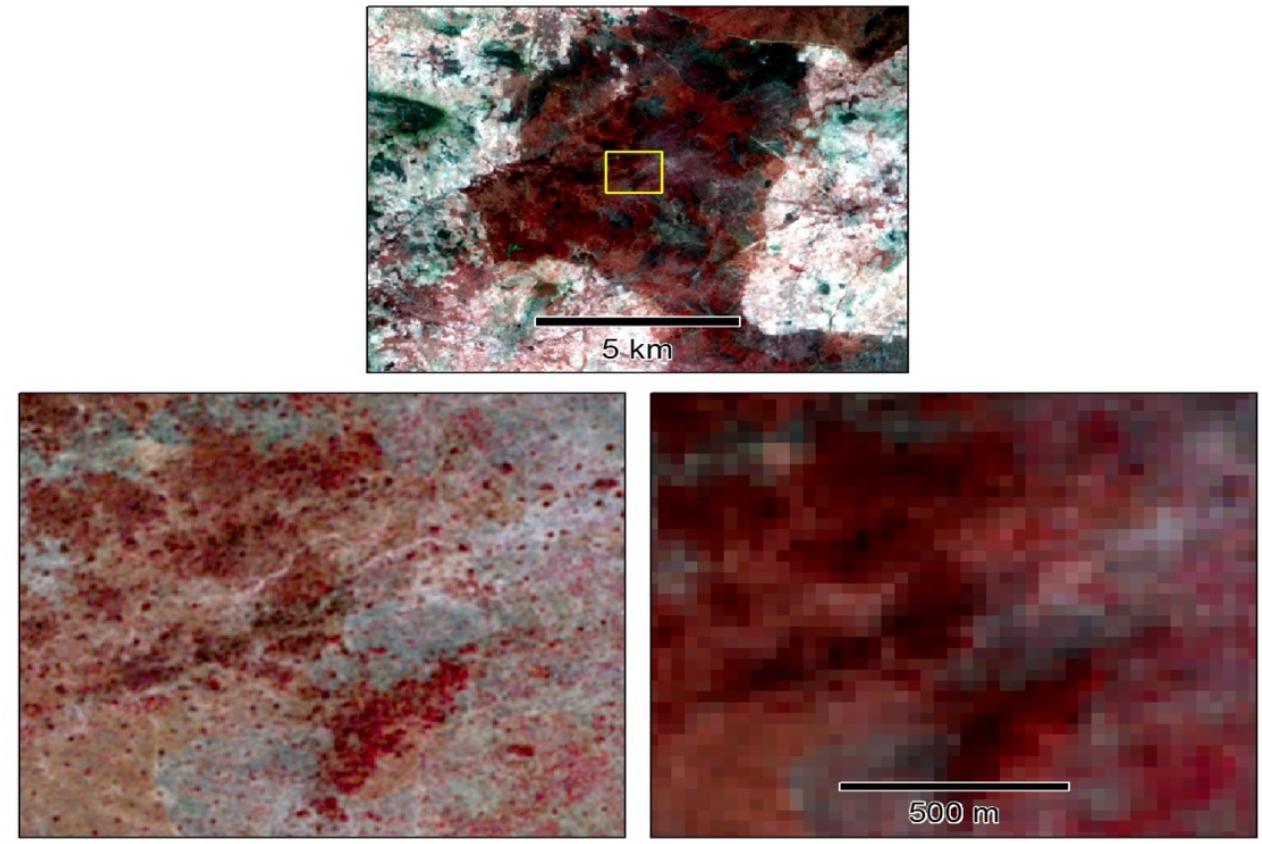

Figure 2.4: An example of a false colour composite of Landsat $8 \mathrm{OLI}$ image (green, red and near infrared spectral bands) from southern Burkina Faso (top). Close-up images demonstrate difference in spatial resolution between the high resolution RapidEye image (left) and medium resolution OLI image (right) for the area indicated by the yellow rectangle. Both images were acquired in February 2014. 


\section{Stratification of project area}

Given spatial variation in carbon stock and dynamics, precision in measurement requirements urge for a differentiated assessment of various geographical variations for carbon stock estimates by arranging or classifying into groups to form relatively homogenous classes with similar carbon stocks (Pearson et al. 2013). The steps include:

1) Delineating complex mosaics into homogenous areas by vegetation types or land use.

2) Select and apply sampling methods for each stratum.

3) Finally, compile obtained data and estimate carbon stocks for each strata and project area.

\section{Methods of stratification}

Stratification can be achieved in the following ways:

1) GPS ((i).2 for instructions) - This is carried out by using the Geographical Information System software programme to store, analyse and report data. Although this may be a tedious and time-consuming approach, it is cheaper than other methods and is therefore considered.

2) Remote sensing (section (i).(2).b) - This entails the use of aerial photography or satellite images and GIS software for mapping vegetation types and land use.
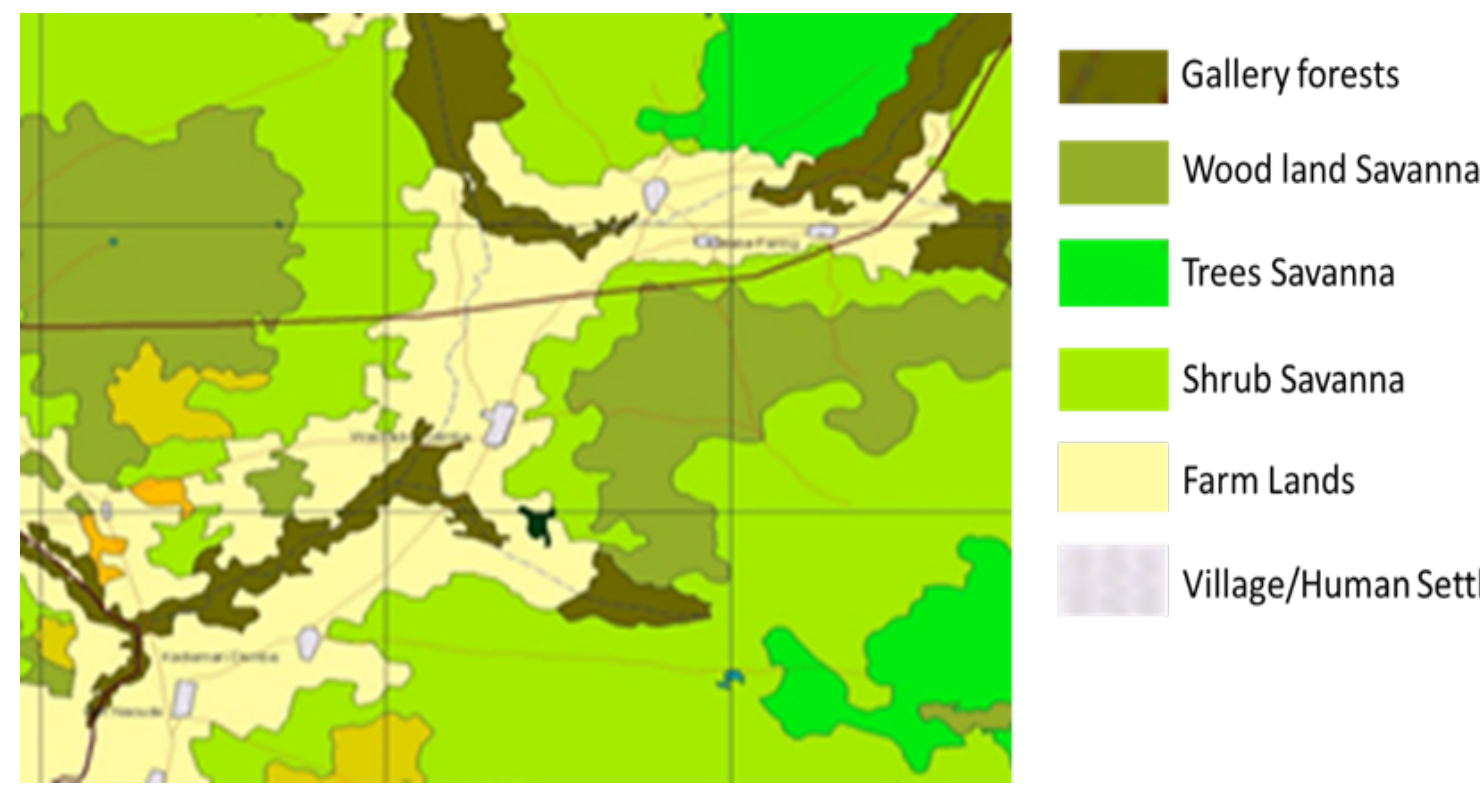

Shrub Savanna

Farm Lands

Village/Human Settlements

Figure 2.5: Example of a stratified plot of land (Velingara Forest in Southern Senegal)

\section{Carbon pools}

In a given ecosystem, there are several reservoirs of carbon that can be measured and monitored. These are indicated in figure 2.7.

\section{Carbon pool selection and frequency of measurement}

Selecting the precise carbon pools for inventory is affected by the project type, size of the pool, rate of change, cost to measure and attainable accuracy (MacDicken 1997 a, b, Brown 
2002). A selective or partial accounting system can be used but it must contain all relevant pools expected to decrease or increase (Brown 2002).

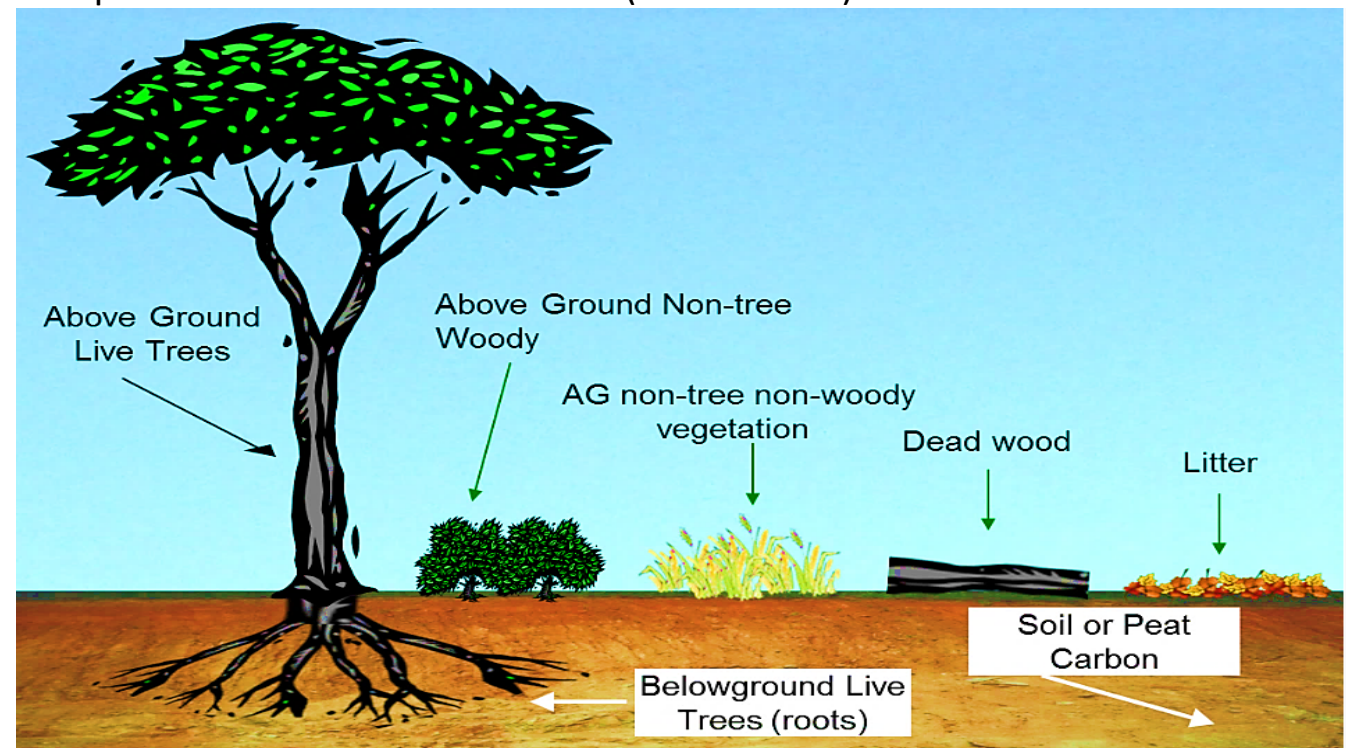

Figure 2.6: The various carbon pools present in a given environment

Table 2.2: A selection of carbon pools that can be measured in different projects

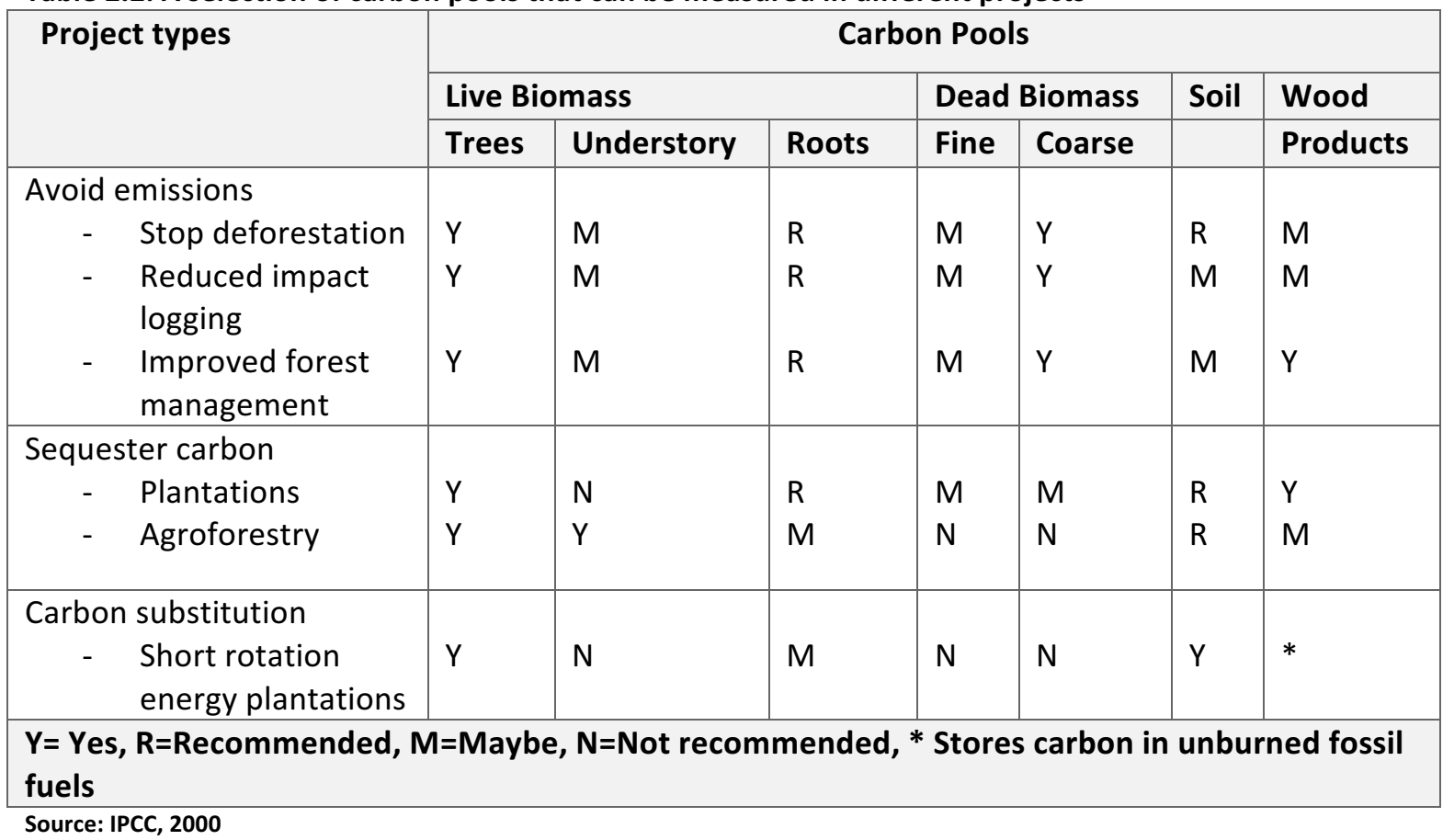

Table 2.2 gives a summary of pools that can be measured in various land-based carbon project scenarios; carbon emission, sequestration and substitution. In carbon sequestration projects, measuring the carbon pools in trees and wood products would be most beneficial as the change in the pools would be large.

Above-ground biomass is the most dynamic carbon pool for land use systems and projects involving trees. It is likely to change frequently or annually, much faster than other pools for all projects involving tree planting. The measurement frequency depends on the stock in above-ground biomass pool at the pre-project implementation phase (known as baseline 
scenario). If the stock is zero or insignificant, as with afforestation or reforestation projects in bare lands, the annual carbon accumulation is likely to be significant and should be measured every three years. Whereas in the scenario of forest management projects (also known as avoided deforestation), the above-ground biomass is likely to be present in considerable amounts at the start of the project, therefore, annual monitoring is not required, (Ravindranath and Ostwald 2007).

On the whole, the measurement frequency of above-ground biomass which usually ranges from once a year to every 2-3 years is reliant on the carbon stocks at the beginning of the project, the growth rate of the biomass and the objective of the project.

\section{Definition of measurement parameters and sampling methods: shape and number of plots}

\section{Definition of parameters}

The consequential estimation and monitoring of carbon stocks in a project requires the measurement of parameters. These are given below.

Table 2.3: Parameters for estimating carbon stocks in above-ground biomass

\begin{tabular}{|c|c|}
\hline Carbon pool & Parameters to be measured and recorded \\
\hline Above-ground biomass of trees and shrubs & $\begin{array}{l}\text { - } \begin{array}{l}\text { Name of species (including local name if } \\
\text { - }\end{array} \\
\text { Diameilable) } \\
\text { Height }(\mathrm{m}) \\
\text { - } \text { Crown extent: full crown or percent } \\
\text { - } \text { crown damaged } \\
\text { - } \text { shrubs weight and number of stems for } \\
\text { Origin: regenerated or planted }\end{array}$ \\
\hline $\begin{array}{l}\text { Above-ground biomass of herb or ground-layer } \\
\text { vegetation (smaller shrubs) }\end{array}$ & $\begin{array}{l}\text { - Name of species } \\
\text { - Density of herbs and smaller shrubs } \\
\text { (number/plot) } \\
\text { - } \quad \text { Fresh weight of herb layer biomass }\left(\mathrm{g} / \mathrm{m}^{2}\right)\end{array}$ \\
\hline
\end{tabular}

Source: Ravindranath and Ostwald 2007

\section{Sampling methods: shape, area and number of plots}

Sampling is the process by which inference is made to the whole project area by examining parts of it. The main goal is to get a reliable estimate with minimal cost (Pearson et al.

2005). Measurements for carbon inventories are taken in a number of plots. The average value obtained when all plots are combined represent the wider population, and by using the confidence interval, the accuracy and how representative the value is can be determined. Typically, a confidence level of $95 \%$ is used and portrays that 95 times out of 100, the true carbon density lies within the interval (Pearson et al. 2005). 
There are two types of sample plots that can be used for sampling trees: permanent plots and temporary plots. Permanent plots are more statistically efficient and permit verification over time, and are therefore more suitable for carbon dynamics estimation in a project area consisting of mainly trees. Additionally, the sizes and shapes of the sample plots have a trade-off between accuracy, precision, measurement time and cost of measurement. Temporary plots are suitable for assessing current stocks. It is also important to differentiate between single plots of fixed sizes or nested plots containing sub-units of different sizes (Lackmann 2011). Plots can also be classified according to their shapes, the most popular for vegetation analyses are circular, rectangular and square plots, though strips are also used.

Identifying the number of plots required to be measured or monitored for estimating carbon stocks is a crucial step in the project. The number of plots should be chosen with statistical rigor to get a correct assessment of the impact of a land-based project on carbon stocks, round wood production or soil organic matter (Ravindranath and Ostwald 2007).

The following steps are used to calculate the number of plots:

- Step 1- Identify the precision level.

- Step 2-Identify area to collect preliminary data.

- Step 3- Estimate mean carbon stock and variance from the preliminary data.

- Step 4-Calculate the number of plots using the equation below:

Equation 2.1: Common formula to estimate number of plots

$$
n=\left[\frac{t \times s}{\left(\frac{S_{y x} \times x}{100}\right)}\right]^{2}
$$

Where:

- $\mathrm{n}=$ number of plots to be measured

- $\mathrm{S}_{\mathrm{yx}}=$ estimation error

- $\mathrm{t}=$ student $\mathrm{t}$ value

- $S=$ variance

- $\mathrm{X}=$ mean value

Alternatively, an online tool for calculating number of plots is available at:

http://www.worldagroforestry.org/downloads/Publications/PDFS/TM11192.pdf (Aynekulu et al. 2011).

The selection of sample plot locations must be free of bias. This statistical error is avoided by firstly examining the project boundary and the map of the area, selecting if plots will be randomly or systematically sampled and determining the exact sites using GIS data. Tropical forests and woodlands require larger sampling plots due to their sizes and extensive canopies.

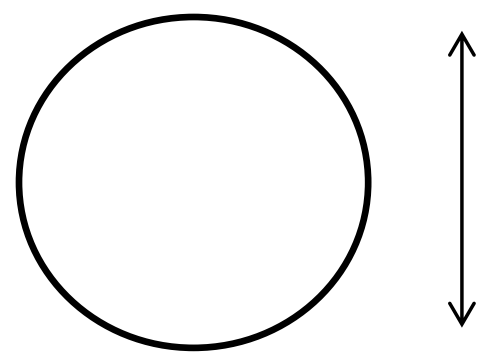



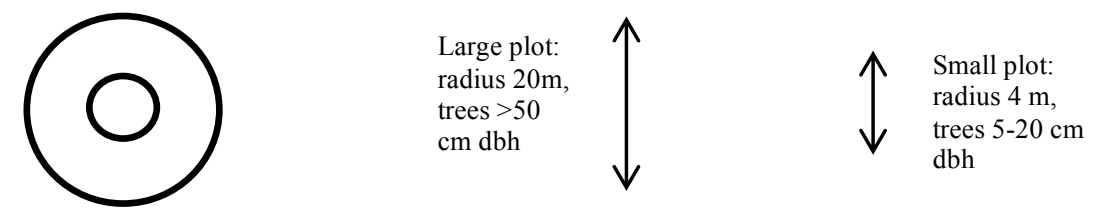

Figure 2.7: An example of the DBH of trees and the approximate radii used in fixed plots (Source: Pearson et al. 2007)

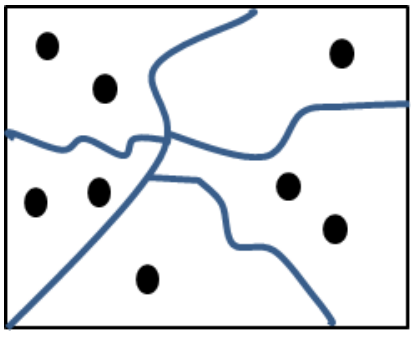

(a) Random sampling

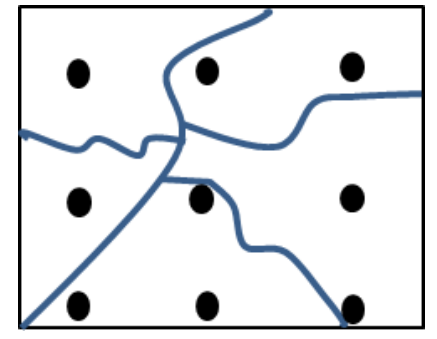

(b) Systematic sampling

Figure 2.8: An example of sampling designs, (a) random and (b) systematic

\section{Conduct field measurements, record and compile data}

To begin field measurements, a number of prerequisites are required, namely (Ravindranath and Ostwald 2007):

- Trained staff

- Information about the project area

- Instruments and materials needed for the measurements

- Arrangement for plant sample collection

- Equipment for recording data

Following these arrangements, field experiments can commence assuring further accuracy and time management. The instruments needed for measurements and recording data for carbon inventory are listed below.

Table 2.4: A list of all instruments and materials needed to conduct field experiments

- Measuring tape - long $(5,30,50 \mathrm{~m})$ and fine to allow measurement of DBH $(1-1.5 \mathrm{~m})$

- Clinometer - estimating tree height

- Pegs for marking boundaries

- Paint and brush or markers for marking point of DBH measurement

- Global Positioning System (GPS)

- $\quad$ Balance (for weighing shrubs and woody biomass)

- $\quad$ Sheets and pencils for recording data

- Metal quadrat for sampling herbaceous vegetation

- Calipers to measure DBH of small stems

- Aluminum tags for marking trees

- Cloth bags or paper bags to collect litter or herbaceous vegetation 
Measuring above-ground biomass of trees.

Calculating the above-ground biomass of trees requires notes and measurements of a number of parameters: the species, diameter at breast height (DBH), the crown radius and tree height (See table 2.3).

- Tree diameter at breast height ( $1.3 \mathrm{~m}$ above ground) is measured using a tape which provides the circumference, or a DBH tape which gives the DBH directly. The DBH is then recorded in centimetres on the data sheet. If the tree has a number of shoots, the DBH for all shoots are measured.

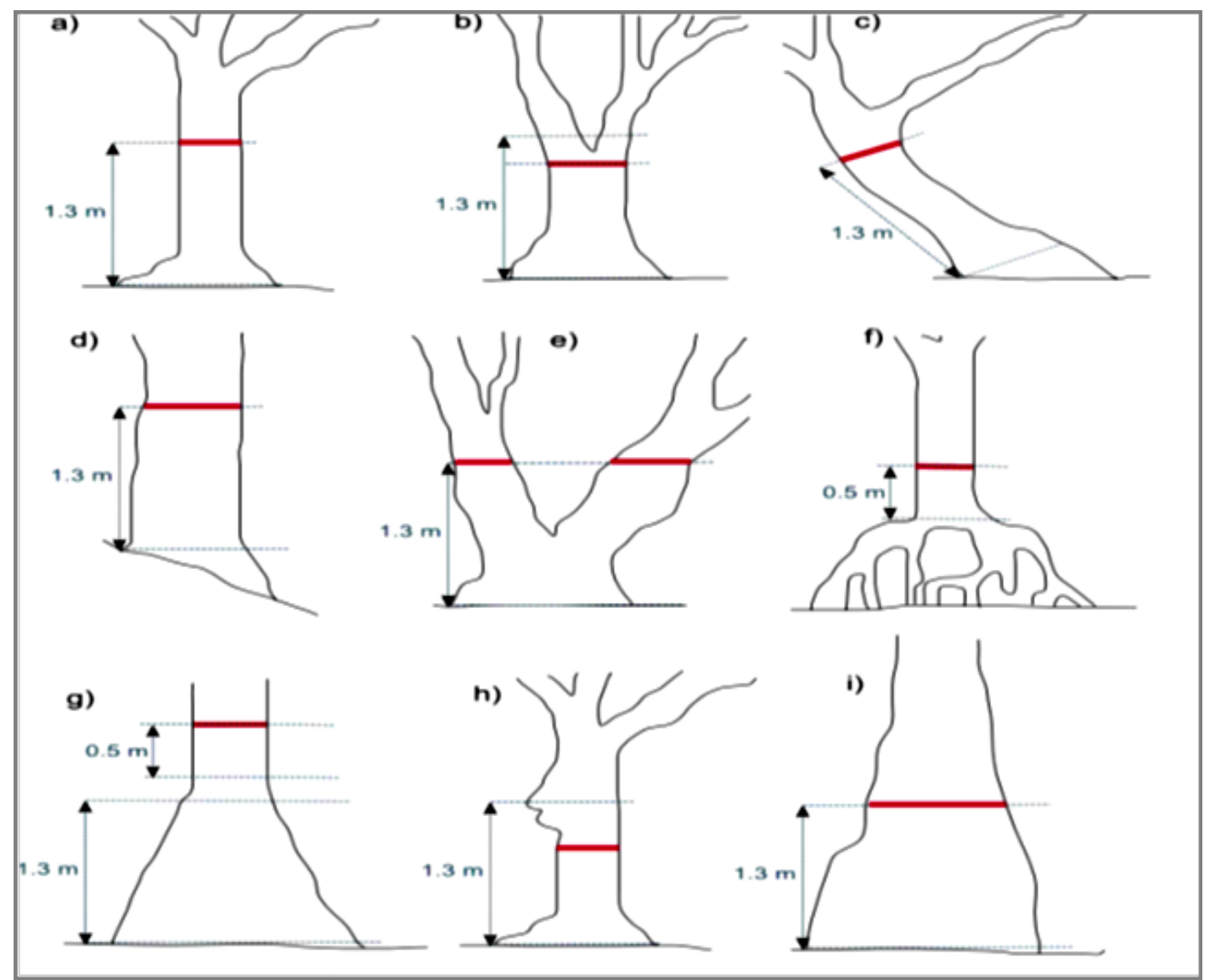

Figure 2.9: Measuring the diameter at breast height of varying shoots and forms of trees (Pearson et al. 2005

- Measuring the height of the tree can be done in a number of ways:

i) Using measuring instruments - If the tree is smaller than $5 \mathrm{~m}$, then a graduated height stick can be used by holding the stick against the tree. But if it is a big tree, a clinometer is commonly used (but not in dense vegetation). Hypsometers (for example, Suunto) are also widely used and do not require calculations. When using a clinometer, the worker stands a considerable distance away from the tree (note down distance from tree) such that the whole tree can be viewed from the clinometer. If the sample plot is located on a slope it is advised to view the tree from across the slope to maintain the distance.

a) Using the clinometer, align the center line with base of the tree and using a percentage scale, then record the reading. Following this, aim the clinometer 
to the top of the tree and record the reading again on a percentage scale.

The height of the tree can then be determined using the equation below:

Equation 2.2: Formula to determine height of the tree using clinometer reading

$$
\text { Height }(m)=\underline{\text { top angle }(\%)-\text { base angle }(\%)] \times \text { horizontal distance }}
$$

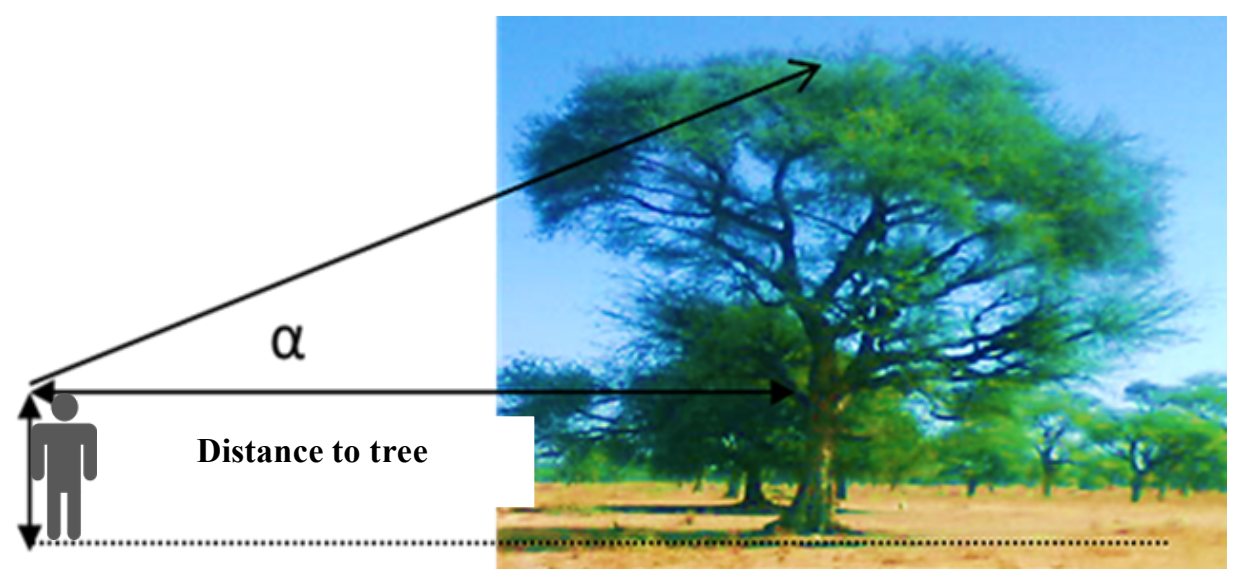

Figure 2.10: Estimating tree height using the clinometer method

ii) Using a height equation - This method correlates with the diameter at breast height (DBH). A regression equation can be formulated for a given number of species, approximately 30 samples, using height and DBH measurements of trees with different heights. The height can be estimated from DBH data for a given tree species using the following equation (Ravindranath and Ostwald 2007):

Equation 2.3: Where: $\mathrm{D}=\mathrm{DBH}, \boldsymbol{a}=$ constant, $b=$ regression coefficient Height $(\mathrm{H})=a+b \mathrm{D}$

NB: It is important to note the health of the trees being documented. For instance, the percentage of damage on a tree crown, if any, and if the tree is dead, fallen or standing. These factors affect the carbon stock estimation of the project area.

\section{Recording and compiling data}

All measurements of tree species, heights and DBH recorded on the data sheet are then transferred to an Excel file for further analysis. An example of what a data set may look like is shown in Table 2.5 . 
Table 2.5: A sample of information recorded and compiled in a database

\begin{tabular}{|c|c|c|c|c|c|c|c|c|c|c|c|}
\hline Forest Name & Placette & Species in plots & Number of Individuals & Number of stems & Br. weight & DBH(cm) & BA(cm) & $\mathrm{H}(\mathrm{m})$ & Cover (\%) & Code1 & Code2 \\
\hline Patako & PS1131 & Combretum glutinosum & 1 & 1 & 1 & 10.5 & 86.590148 & 6 & 45 & Com & glu \\
\hline Patako & PS1131 & Cordyla pinnata & 2 & 1 & 1 & 48.6 & 1855.079 & 14 & 45 & Cor & pin \\
\hline Patako & PS1131 & Bombax costatum & 3 & 1 & 1 & 38.7 & 1176.283 & 15 & 45 & Bom & $\cos$ \\
\hline Patako & PS1131 & Lannea acida & 4 & 1 & 1 & 25.5 & 510.70516 & 11 & 45 & Lan & aci \\
\hline Patako & PS1131 & Terminalia micropetra & 5 & 1 & 1 & 6.1 & 29.224666 & 4.5 & 45 & Ter & $\mathrm{mac}$ \\
\hline Patako & PS1131 & Combretum glutinosum & 6 & 1 & 0.5 & 6.6 & 34.211944 & 5 & 45 & Com & glu \\
\hline Patako & PS1131 & Combretum glutinosum & 6 & 2 & 0.5 & 9 & 63.617251 & & 45 & Com & glu \\
\hline Patako & PS1131 & Combretum glutinosum & 7 & 1 & 0.333 & 7.5 & 44.178647 & 4.5 & 45 & Com & glu \\
\hline Patako & PS1131 & Combretum glutinosum & 7 & 2 & 0.333 & 6.5 & 33.183072 & & 45 & Com & glu \\
\hline Patako & PS1131 & Combretum glutinosum & 7 & 3 & 0.333 & 5.4 & 22.90221 & & 45 & Com & glu \\
\hline Patako & PS1131 & Combretum glutinosum & 8 & 1 & 0.5 & 7.8 & 47.783624 & 4.5 & 45 & Com & glu \\
\hline Patako & PS1131 & Combretum glutinosum & 8 & 2 & 0.5 & 5.3 & 22.061834 & & 45 & Com & glu \\
\hline Patako & PS1131 & Terminalia micropetra & 9 & 1 & 1 & 23.3 & 426.38481 & 9.5 & 45 & Ter & $\mathrm{mac}$ \\
\hline Patako & PS1131 & Terminalia micropetra & 10 & 1 & 1 & 5.1 & 20.428206 & 4 & 45 & Ter & $\operatorname{mac}$ \\
\hline Patako & PS1131 & Detarium microcarpum & 11 & 1 & 1 & 21 & 346.36059 & 7 & 45 & Det & mic \\
\hline Patako & PS1133 & Bombax costatum & 1 & 1 & 1 & 38.5 & 1164.1564 & 15 & 55 & Bom & $\cos$ \\
\hline Patako & PS1133 & Bombax costatum & 2 & 1 & 1 & 52.5 & \begin{tabular}{|l|}
2164.7537 \\
\end{tabular} & 18 & 55 & Bom & $\cos$ \\
\hline
\end{tabular}

\section{Biomass estimates and sources of uncertainty}

Biomass can be estimated using two methods:

- Direct methods: destructive sampling and development of allometric equations.

- Indirect methods: applications of existing allometric equations, biomass expansion factor and volume equations.

Tree measurements using traditional forest inventories will be analysed using allometric equations to obtain individual trees' biomass which are then used for estimating carbon stocks of the project area.

\section{(a) Estimating biomass using destructive sampling}

A good sampling design should be established based on pre-existing data set on abundance of various species and distribution of tree in size class. A number of allometric models have been built based on direct sampling of trees of various size and various species. Depending on the objectives and the availability of the equations - either species specific allometric models or generic allometric model mosaics can be used. Allometric equations are a fundamental tool for non-destructive estimation of biomass in woody vegetation. These equations express tree biomass as a function of easy-to-measure parameters such as diameter, height, or wood density, or a combination of these (Brown 2002, Chave et al. 2005).

The number of trees selected varies, but the population $(n)$ harvested should be representative enough to allow statistical inferences. The measurement protocol for each selected tree in the inventory plots included 10 successive steps:

1. Measure of $\mathrm{DBH}$, height and crown diameter

2. Cut the tree at the base

3. Measure the trunk length (from the base to the initial ramifications)

4. Separate the parts of the tree in three categories (trunk, branches and leaves)

5. Weigh the different parts in each category

6. Collect samples from each category and weigh their fresh mass (FM) with an electronic balance

7. Dehydrate the samples in a ventilated oven at $60^{\circ} \mathrm{C}$ until their dry mass (DM) remains constant 
8. Calculate the relative moisture content $\mathrm{RMC}=(\mathrm{FM}-\mathrm{DM}) / \mathrm{FM}$ of the samples

9. Convert the FM into DM by applying the appropriate conversion factors for each category of the tree

10. Estimate the total dry biomass of the tree by summing up the masses of the three categories (trunk, branches and leaves).

The fundamental measurements acquired for each tree within each inventory plot include the tree species name, the Diameter at Breast Height (DBH) and trunk circumference, the total height and tree Crown Diameter (CD), the wet and dry mass, as well as the relative moisture content of samples from each of the three categories (trunk, branches, leaves), and the weights of these samples.

Table 2.6: An example of a dataset for constructing allometric equations

\begin{tabular}{|c|c|c|c|c|c|c|c|c|c|c|}
\hline Location & Bala & Bala & Bala & Bala & Bala & Bala & Bala & Bala & Bala & Bala \\
\hline Genus & Combretum & Combretum & Combretum & Combretum & Combretum & Combretum & Combretum & Combretum & Combretum & Combretum \\
\hline Species & glutinosum & glutinosum & glutinosum & glutinosum & glutinosum & glutinosum & glutinosum & glutinosum & glutinosum & glutinosum \\
\hline X (UTM) & 713141 & 713141 & 713141 & 713141 & 713141 & 713141 & 713141 & 713141 & 713141 & 713141 \\
\hline Y (UTM) & 1556067 & 1556067 & 1556067 & 1556067 & 1556067 & 1556067 & 1556067 & 1556067 & 1556067 & 1556067 \\
\hline DBH & 10.6 & 9.15 & 12.1 & 8.2 & 7.25 & 12.25 & 8.35 & 7.65 & 14.25 & 17.4 \\
\hline Circonference & 34.5 & 30.1 & 39.5 & 26.2 & 23.4 & 39 & 26 & 24 & 46 & 57 \\
\hline Tree Height_[m] & 5 & 5.5 & 6.5 & 5.5 & 4.5 & 5 & 4.5 & 5 & 6 & 7 \\
\hline Stem Lenght_[m] & 2.1 & 1.4 & 1.2 & 1.7 & 2 & 2.1 & 1.2 & 0.9 & 1.5 & 2 \\
\hline Crown Diameter_[m] & 4.65 & 2.55 & 4.94 & 3.3 & 3.75 & 4.85 & 3.05 & 4.42 & 5.45 & 7.9 \\
\hline Humid Mass of Stem_[kg] & 24 & 8.5 & 17 & 11.6 & 8 & 31.5 & 9.3 & 6.4 & 33 & 108.5 \\
\hline Humid Mass of Branches_[kg] & 24.5 & 16 & 72 & 14.5 & 11 & 35 & 13.5 & 32.7 & 77.5 & 206.5 \\
\hline Humid Mass of leaves_[kg] & 6 & 2.6 & 13.5 & 6 & 3.2 & 17.2 & 3.1 & 12.7 & 18.5 & 44 \\
\hline Humid Mass Total_[kg] & 54.5 & 27.1 & 102.5 & 32.1 & 22.2 & 83.7 & 25.9 & 51.8 & 129 & 359 \\
\hline Moisture of Stem_[\%] & 0.74 & 0.73 & 0.76 & 0.74 & 0.76 & 0.74 & 0.73 & 0.72 & 0.73 & 0.75 \\
\hline Moisture of Branches_[\%] & 0.71 & 0.68 & 0.78 & 0.7 & 0.69 & 0.71 & 0.69 & 0.71 & 0.72 & 0.7 \\
\hline Moisture of Leaves_[\%] & 0.63 & 0.61 & 0.59 & 0.64 & 0.62 & 0.69 & 0.61 & 0.62 & 0.6 & 0.63 \\
\hline Dry Mass of Stems_[kg] & 17.76 & 6.205 & 12.92 & 8.584 & 6.08 & 23.31 & 6.789 & 4.608 & 24.09 & 81.375 \\
\hline Dry Mass of Branches_[kg] & 17.395 & 10.88 & 56.16 & 10.15 & 7.59 & 24.85 & 9.315 & 23.217 & 55.8 & 144.55 \\
\hline Dry Mass of Leaves_[kg] & 3.78 & 1.586 & 7.965 & 3.84 & 1.984 & 11.868 & 1.891 & 7.874 & 11.1 & 27.72 \\
\hline Dry Mass Total_[kg] & 38.935 & 18.671 & 77.045 & 22.574 & 15.654 & 60.028 & 17.995 & 35.699 & 90.99 & 253.645 \\
\hline Dry Mass of Sample_[kg] & 1.07 & 0.8 & 1.36 & 0.6 & 0.56 & 1.55 & 0.79 & 0.88 & 1.83 & 2.51 \\
\hline Biomasse_totale & 40.005 & 19.471 & 78.405 & 23.174 & 16.214 & 61.578 & 18.785 & 36.579 & 92.82 & 256.155 \\
\hline
\end{tabular}

\section{Estimating biomass using allometric equations}

Inputs to an allometric equation usually include $\mathrm{DBH}$, tree height and wood density which can be derived from literature or online data bases such as:

http://db.worldagroforestry.org. Sometimes, DBH is the only input and the data however results in a significant amount of bias (Valbuena et al. 2016).

Table 2.7: Examples of some published allometric equations

\begin{tabular}{|l|l|l|l|}
\hline S/N & Equation & Vegetation & Author \\
\hline 1 & $A G B=0.051 \times\left(d b h^{2} \times H\right)^{0.930}$ & Agroforestry, Western Kenya & Henry et al., 2009 \\
\hline 2 & $A G B=0.091 \times(d b h)^{2.472}$ & Agro-ecosystems, Western Kenya & Kuyah et al., 2012 \\
\hline 3 & $\begin{array}{l}A G B=D B H(1.929+0.116 \times D B H+0.013 X \\
\left.D B H^{2}\right)\end{array}$ & Savanna system, Senegal & Mbow et al. 2013 \\
\hline 4 & $A G B=33338 \times(1-\exp (-2 \times 2245 \times X / 33338))^{2}$ & Tropical Dry forest & Manley et al.2002 \\
\hline 5 & $A G B=0.0673 \times\left(q D^{2} H\right)^{0.976}$ & Pantropical forest & Chave et al, 2014 \\
\hline
\end{tabular}


Table 2.8: Species specific allometric equations

\begin{tabular}{|c|c|c|c|c|c|c|}
\hline Species & $\mathbf{n}$ & Equations & $\mathbf{R}^{2}$ & RSE & Country & Authors \\
\hline $\begin{array}{l}\text { Acacia } \\
\text { Senegal }\end{array}$ & 44 & $\begin{array}{l}\mathrm{y}=0.032 \mathrm{Dbh}^{3}- \\
1.016 \mathrm{Dbh}^{2}+10.87 \mathrm{Dbh}+ \\
7.429\end{array}$ & 0.963 & - & Sénégal & Thiam et al. 2014 \\
\hline $\begin{array}{l}\text { Pterocarpus } \\
\text { erinaceus }\end{array}$ & 105 & $V f=3.024 D 2.259$ & 0.873 & 0.353 & Gaya (Niger) & Rabiou et al. 2015 \\
\hline $\begin{array}{l}\text { Faidherbia } \\
\text { albida }\end{array}$ & 9 & $y=7.985 D b h+32.277$ & 0.33 & 0.2447 & Kollo (Niger) & Larwanou et al. 2010 \\
\hline $\begin{array}{l}\text { Combretum } \\
\text { nigricans }\end{array}$ & 100 & $\begin{array}{l}y(g)= \\
1.2289 \times\left(X^{\wedge} 2.5806\right) \times 10^{\wedge}(- \\
3)\end{array}$ & 1 & & N'goukan (Mali) & Henry et al. 2011 \\
\hline $\begin{array}{l}\text { Anogeissus } \\
\text { leiocarpa }\end{array}$ & 20 & $\begin{array}{l}\ln (y)=-2.4996+ \\
1.5133 \ln (\mathrm{Dbh})+1.1256 \\
\ln (\mathrm{H})\end{array}$ & 0.9576 & & Benin & Guendehou et al. 2012 \\
\hline $\begin{array}{l}\text { Ziziphus } \\
\text { mauritiana }\end{array}$ & 9 & $y=5.46 \mathrm{Dbh}+6.6167$ & 0.99 & 0.2182 & Kollo (Niger) & Larwanou et al. 2010 \\
\hline
\end{tabular}

Source: Moussa et al. 2015

Chave et al. (2014), recently revised a general allometric equation for estimating aboveground biomass in tropical forests and woodlands. This allometric equation displayed in Table 3.7 can be used to determine carbon stocks in various ecosystems. FAO has initiated the following global allometry database http://www.globallometree.org.

\section{Estimating biomass using an expansion factor and volume equations}

The biomass expansion factor is the relationship between the total tree biomass and the stem biomass. It is used to estimate the total tree biomass using the stem biomass.

Equation 2.4: Attaining total tree biomass using a biomass expansion factor

$$
\mathrm{B}_{\text {tot }}=\mathrm{B}_{\text {stem }} * \mathrm{BEF}
$$

Where: $\mathrm{B}_{\text {tot }}=$ Total tree biomass, $\mathrm{B}_{\text {stem }}=$ Stem biomass, $\mathrm{BEF}=$ Biomass expansion factor

This method estimates; (i) the volume of the timber in the tree stem; (ii) the biomass in the stem by multiplying the volume of timber by the wood density; and (iii) the above-ground biomass, by multiplying the stem biomass volumes by an appropriate biomass expansion factor.

The general equation for above-ground biomass $(A G B)$ is: $A G B=V \times \rho \times B E F$

- $\quad$ where $V=$ stem volume $\rho=$ dry wood density; BEF = biomass expansion factor for above-ground biomass (branches and canopy). 


\subsection{Carbon dioxide emission reduction through efficient wood energy (improved}

stoves)

Implementation of efficient cooking stoves benefits both the health of the public and the environment through the consequential reduction in carbon dioxide emissions. The rate of deforestation to attain fuelwood is reduced as less fuelwood is needed when cooking with efficiently designed cooking stoves. Additionally, the cooking stoves are designed to relieve rural families across West Africa from the possibilities of getting burnt and harmful emissions produced while cooking.

The relative amounts of emissions produced from the use of efficient cooking stoves are difficult to interpret as each individual stove is dependent on various parameters such as the type and design of the stove and the source of wood fuel (Bhattacharya et al. 2002). Grupp (2002) stipulated that cooking is responsible for approximately $5 \%$ of all greenhouse gases worldwide, which is nearly 2 billion tonnes of carbon dioxide equivalent emissions a year (Adria and Bethge 2013).

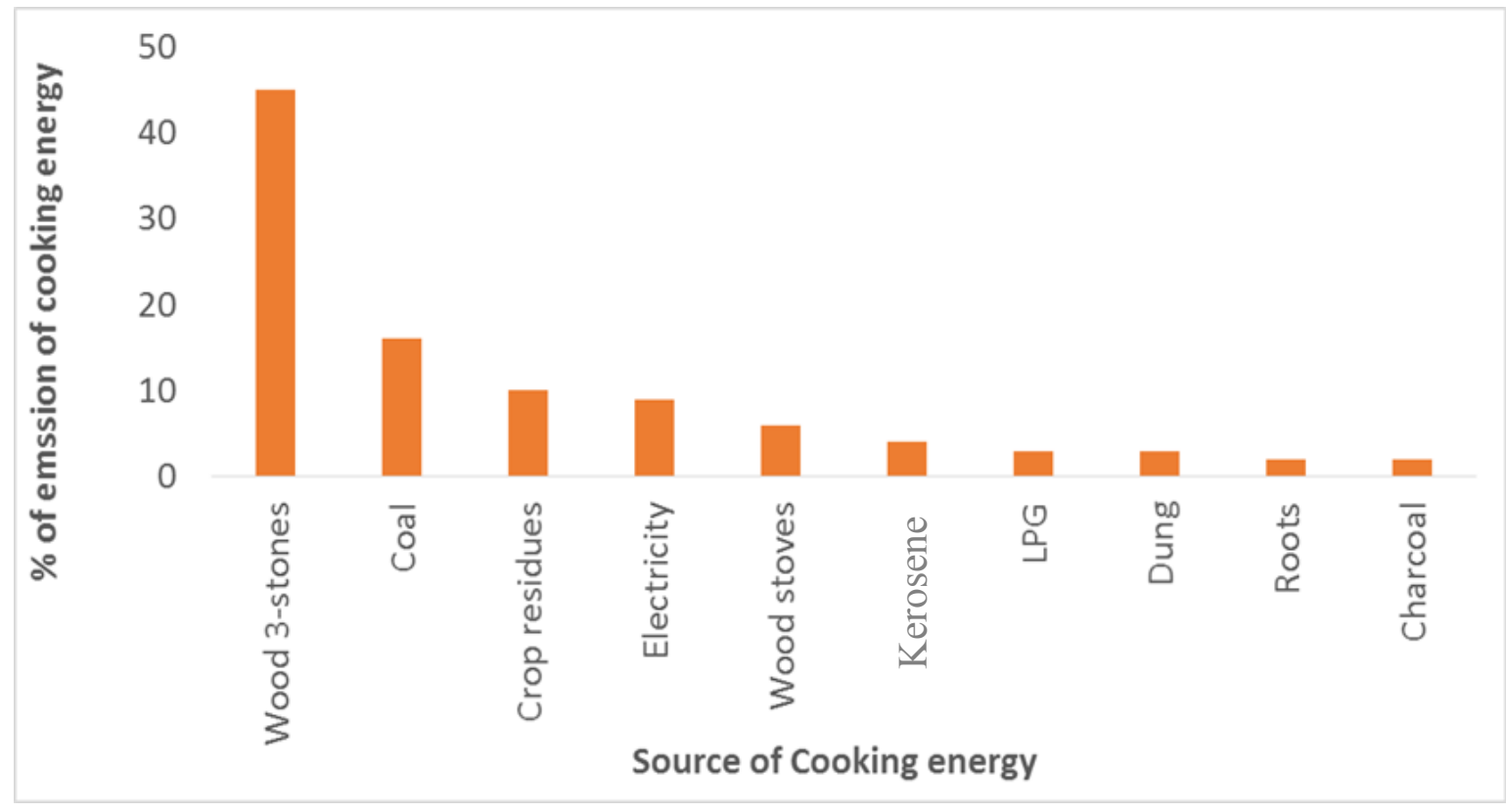

Figure 2.11: Relative global emissions of various cooking fuels (Source: Grupp 2004)

Figure 2.11 depicts the carbon dioxide emissions released by various cooking fuels. The three-stone fire produces more than three-quarters of the carbon dioxide released from cooking (with severe health implications), while an improved biomass cooking stove reduces these emissions to $6 \%$. Hence, wood energy cooking stoves could reduce greenhouse gas emissions significantly at a net economic benefit or low cost (Adria and Bethge 2013). Further details on wood fuels and efficient cooking stoves are discussed in Section B-4.

Emissions from cooking stoves can be measured and monitored using both direct and indirect methods (Treemer 1997):

i) Direct methods - This measurement is carried out at the source whereby a hood is placed over the stove to capture emissions. 
ii) Indirect methods - In a room resembling a rural home, the influence of the stove and the emissions are measured using a gas chamber and the emission source strength is calculated by performing a mass balance for the pollutant in the chamber. Another indirect method is the use of emission factors that convert flat emission rate from units of wood or charcoal used for cooking.

\subsection{Estimating the sources of uncertainty}

Uncertainty is the consequential doubt that arises from conducting measurements. The sources of uncertainties and errors in carbon inventories are attributable to the following (Bell 2001):

i) The measurement process - The method of measurement may be challenging such as estimating the height of trees in a sloped area. Although numerous methods have been verified in estimating different forms of biomass, which may perhaps seem impossible to analyse (e.g. tall trees in rain forests, slanting tree trunks), there is still a certain amount of error and uncertainty that arises as opposed to measuring $\mathrm{DBH} /$ tree heights of simpler trees and biomass.

ii) The measurement instruments - Instruments used could be outdated, broken and old, with high usage history which could impede the values acquired from the measurement procedure.

iii) Human error - This is unavoidable error which occurs naturally through faults in reading instruments and data recording, among others. A usual practice to reduce that is to set peer cross-check with the inconvenience of spending more time in data collection.

iv) Allometric models used - Certain allometric models produce results with a significant amount of bias in particular when the conditions of application are very different from the allometry sources.

The relative amount of uncertainty in a carbon inventory can be reduced by checking the measurement attained twice or thrice before proceeding. However, this may be time consuming if the benefit of reduced uncertainty offsets the time consumption. Additionally, attaining averages of the measurements to acquire the best estimate, increasing workshops and training workers on conducting carbon inventories and advanced technology would greatly reduce uncertainty. 


\section{B-1/Development of fruit and vegetable trees for emission reduction and carbon sequestration}

\section{Rationale and objectives}

Fruit and vegetable trees contain sufficient amounts of woody biomass to act as carbon sinks. However, the carbon sequestration of fruit and vegetable tree plantations alone may not be as high as it is in forests due to reduced branches and woody mass. Fruit and vegetable trees have the benefits of improving food security, nutritional value, agricultural income and sustainable use of land when planted together.

An additional advantage is the ability of fruit and vegetable trees to survive in various environments where forests may be unable to thrive. This is highly dependent on the type of plantation, but is beneficial to climate change and the soil environment as nutrient cycling and decomposition of litter from the existing fruit and vegetable trees increase the fertility and organic matter of soil. This allows for the growth of more herbaceous vegetation and agricultural produce. Such processes increase the overall rate of carbon sequestration thereby altering the concentration of carbon dioxide gas in the atmosphere and reducing climate change as an ample number of trees are grown in areas where there were none to begin with.

The main purpose of promoting the development of fruit and vegetable trees in this toolkit is to increase carbon sequestration and reduce climate change. At the same time, farmers are educated on more sustainable methods to acquire good quality food/products of their preference that enables better nutrition of the West Africa as well as socioeconomic development.

A vast number of indigenous fruit trees are found in the varying climates across West Africa. Some examples are: Mango and African mangoes (Mangifera indica and Irvingia gabonensis), tamarind (Tamarindus indica), baobab (Adansonia digitata L.) and shea tree (Vitellaria paradoxa), among others. These fruit trees were identified as priority species for domestication programmes by the World Agroforestry Centre (ICRAF) in 1995 due to their high nutritional, medicinal and income-generating values (Kalinganire et al. 2008, Tchoundjeu et al. 2008). The coastal areas of West Africa have coconut palm (Cocos nucifera) trees. However, dense forests are scarce due to the saline nature of soils.

The palm trees (Elaeis guineensis) not only enhance the well-being of the environment, but also contribute to socioeconomic development. Martin (1999) highlighted the importance of shade trees for smaller fruit or vegetable trees such banana, coffee, cacao or plantings of annual or perennial vegetables. With the shade trees, yields increased considerably and wood harvesting in forests decreased. This highlights the value of sustainable use of land through trees and agriculture, known as agroforestry, where woody perennials are deliberately integrated with crops and/or animals on the same land with both ecological and economic interactions between the woody and non-woody components (ICRAF 1997).

Developing biocarbon projects in humanized landscapes is a big conundrum due to lack of clarity on land tenure systems that determines the security and risk of deforestation. In Africa, deforestation is frequently a result of the rise in demand for food and fuels due to increasing populations. The forests are cleared for agricultural purposes using techniques 
such as slash-and-burn where the remaining ash is used as fertilizer for the crops to be grown. Deforestation not only results in an increased net flux of carbon dioxide into the atmosphere, but also poses other concerns such as soil erosion. This can destroy newly planted crops and seedlings and cause loss of nutrients leaving land unsuitable for any plant growth whatsoever.

This in turn reduces the quality and quantity of cash crops being grown, as soil nutrient richness is lost and the land left barren. Subsequently, carbon dioxide concentration in the atmosphere is increased, along with the effect of global warming and climate change, while the socioeconomic development of the country faces drawbacks.

To counter deforestation through land restoration, the use of various forms of agroforestry such as reforestation, edge or line planting and farmer-managed natural regeneration (FMNR) can be implemented. Hence, farmers can opt to plant fruit and vegetable trees along with timber trees, native forests or perhaps together, such as the case of palm trees. The World Commission on Forests and Sustainable Development suggested radical and urgent actions to tackle climate change, deforestation and poverty by implementing more extensive support to community-based agroforestry to promote growth of fruit and vegetable trees together (Leakey and Tchoundjeu 2001). Herein, the farmland becomes the communities' and the risks and benefits of food production are shared.

These agroforestry systems provide better quality products with adequate nutritional values, and fertile soils due to leaf litter decomposition. They reduce the need for frequent application of fertilizer, while evidently enhancing sustainable agriculture and land use. As deforestation is considerably reduced, carbon sequestration is enhanced as no trees are being cut down but instead grown, creating more carbon pools in that area. This evidently reduces the pressure on forests and maximizes the sustainable use of land, thus ensuring co-benefits for climate change adaptation and mitigation (Mbow et al. 2014).

Data and information requirements for carbon sequestration in fruit and vegetable trees

Measuring the precise amount of carbon stocks in a fruit and vegetable tree dominated area is challenging due to the vast spatial and temporal heterogeneity of species (Kuyah et al.

2012). However, it is an important task considering that at least $87 \%$ of agroforestry systems in sub-Saharan Africa have more than 10\% tree cover (Kuyah et al. 2012, Zomer et al. 2009). Carbon stocks can be regulated through agroforest projects by:

i) Targeting degraded or deforested lands where afforestation is feasible and allowed

ii) Analysing the climate of the degraded area and other aspects such as economic and ecological benefits to enable selection of the most suitable species to grow; priority species: "the right tree for the right place" although the vegetation map for West Africa has not yet been developed. (ICRAF webpage: http://vegetationmap4africa.org/Vegetation map.html).

iii) Selecting communities and choosing appropriate management and monitoring techniques based on the nature of the plantation, silvicultural practices such as pruning, harvesting, crop rotation and fertilizing, and selecting methods for field and laboratory 
studies. Figure 3.1.1 demonstrates the cycle of carbon sequestration in any given agroforest.

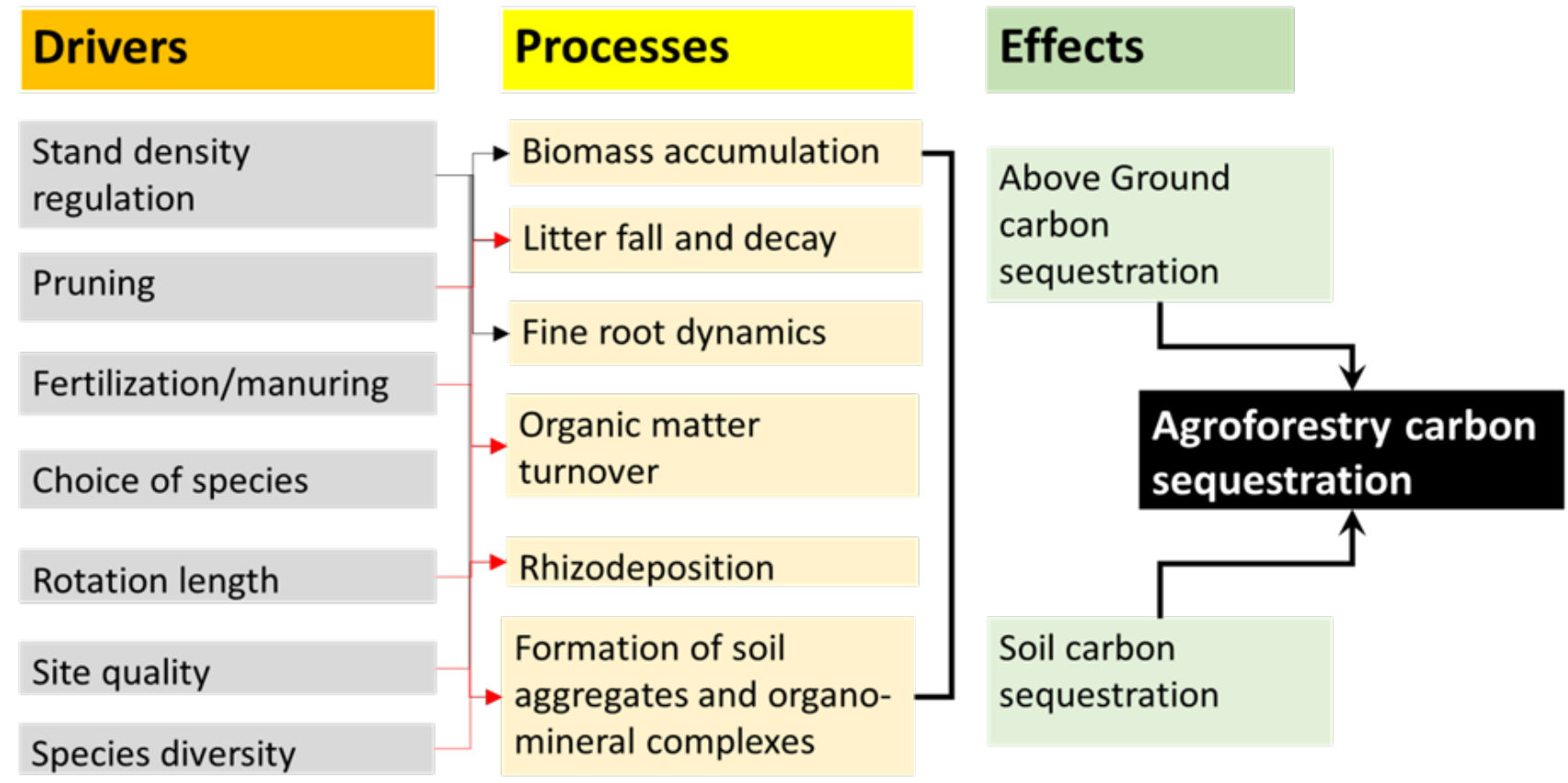

Figure 3.1.1: The drivers, processes and effects of silvicultural practices on carbon sequestration potential on agroforestry (Source: Nair et al. 2010)

The sequestration potential of carbon in agroforests is highly dependent on the species, site quality, management practices and age or rotation length (Nair et al. 2009, Nair et al. 2010). To enable successful project development, the following factors must be determined:

a) Baseline scenario - Enables clear analysis of carbon stock addition in the targeted land before implementation of the project scenario and after.

b) Additionality - The estimated amount of carbon that will be stored as biomass throughout the development of the project from the baseline scenario.

c) Leakage - The consequent net loss of biomass carbon due to conversion of land outside the project boundary affiliated with displacement of farmers and locals.

d) Permanence - The duration of the carbon sequestration project should be a long term scheme to enable maximum storage potential of carbon by all species. 


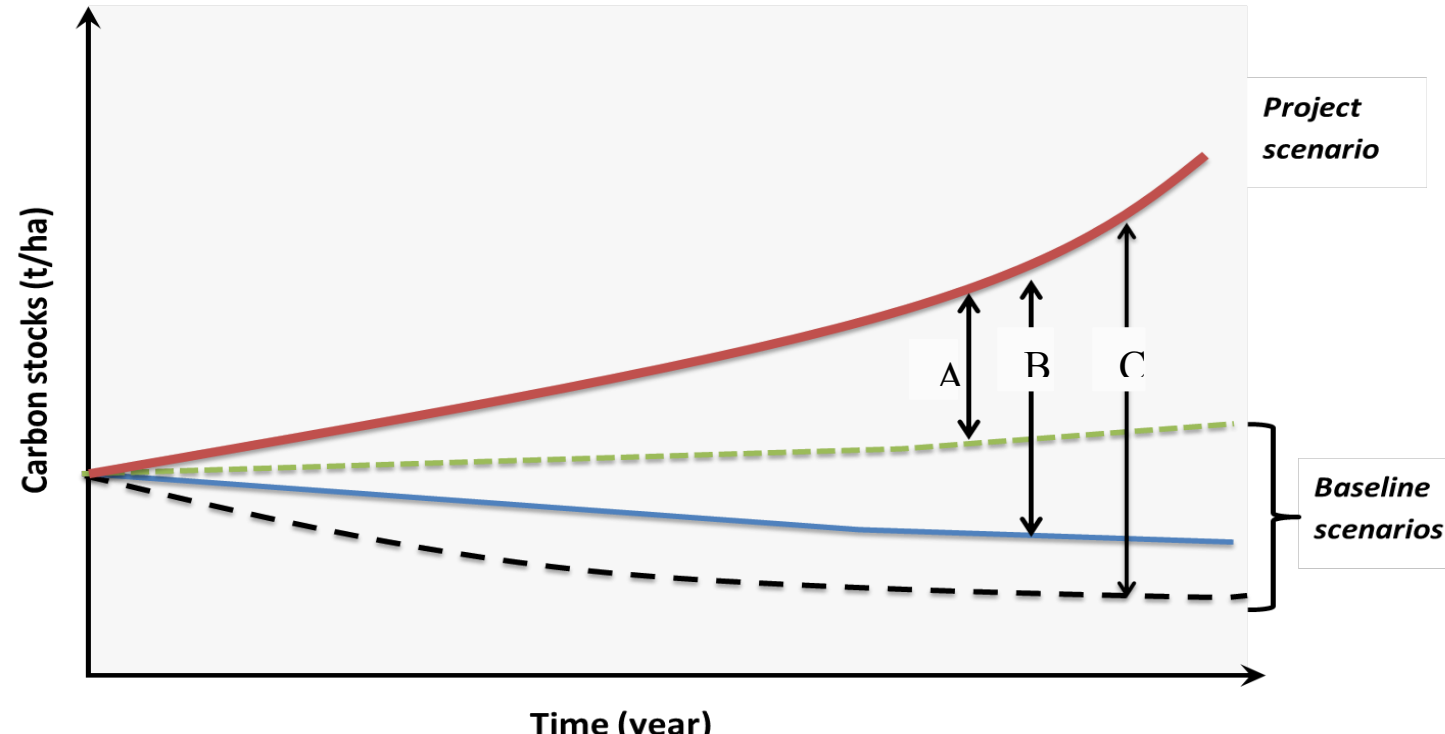

Figure 3.1.2: Illustrates additional carbon sequestration denoted by A, B and C, through the implementation of a project scenario to three varying baseline scenarios

Before the execution of a project, it is important to assess the baseline scenario to determine the additional carbon sequestration (shown by $\mathrm{A}, \mathrm{B}$ and $\mathrm{C}$ ) expected by the implementation of the project. The baseline scenarios given in figure 3.1.2 depict the standard carbon biomass patterns indicating: no changes in carbon stocks, decreasing carbon stocks or steadily increasing carbon stocks. Furthermore, the leakage and the expected permanence of the project must be quantified so as to allow an accurate estimation of carbon sequestration by fruit and vegetable trees.

\section{Carbon abatement potential}

This section targets examples of successful carbon sequestration projects regarding development of fruit and vegetable trees in West Africa. The carbon abatement potential refers to the ability of the fruit and vegetable trees to reduce carbon dioxide concentration from the atmosphere by converting it into biomass or carbon stocks. Below is a table providing information on carbon sequestration potential of different species grown in various countries with different climatic and ecological niches across West Africa.

Table 3.1.1: Examples of carbon sequestration potentials ( $t / h a / y r)$ of various species and climates

\begin{tabular}{|l|l|l|}
\hline Species & Conditions of growth & Carbon sequestration potential \\
\hline $\begin{array}{l}\text { Cocos nucifera (coconut } \\
\text { trees) }\end{array}$ & $\begin{array}{l}\text { Humid tropics, hot } \\
\text { temperatures and along } \\
\text { coastlines }\end{array}$ & $1-5 \mathrm{t} / \mathrm{ha} / \mathrm{yr}$ \\
\hline $\begin{array}{l}\text { Musa acuminata, Musa } \\
\text { balbisiana (banana } \\
\text { plantations) }\end{array}$ & Sub-tropical climates & $6 \mathrm{t} / \mathrm{ha} / \mathrm{yr}$ \\
\hline $\begin{array}{l}\text { Elaeis guineensis (African oil } \\
\text { palm trees) }\end{array}$ & $\begin{array}{l}\text { Humid tropics, semi-arid } \\
\text { tropics }\end{array}$ & $6 \mathrm{t} / \mathrm{ha} / \mathrm{yr}$ \\
\hline Dacryodes edulis (Safou) & Humid and sub-humid tropics & $8 \mathrm{t} / \mathrm{ha} / \mathrm{yr}$ \\
\hline $\begin{array}{l}\text { Theobroma cacao (cacao } \\
\text { trees) }\end{array}$ & Humid tropics & $7 \mathrm{t} / \mathrm{ha} / \mathrm{yr}$ \\
\hline
\end{tabular}


Table 3.1.1 provides additional examples and information on species that can be grown in varying environments. Farmers can opt for trees that sequester more carbon in the project area in order to increase sustainable farming and agricultural practices. Additionally, the species selected must also provide a substantial amount of economic profits.

\section{Costs and investments}

The development of fruit and vegetable trees on farms to enhance carbon sequestration in West Africa requires proper investment. The project needs to generate more financial advantages rather than outgoing costs in whole. A number of cheaper, more efficient alternatives can be used and are given in the methodology section (see section A-2). Primarily, a carbon inventory begins by estimating the project boundary, stratifying the area, identifying parameters and conducting measurements and laboratory analysis. This is where most costs and investments are procured. The following steps in a carbon inventory require substantial amounts of funding:

i) Training staff - This enables attainment of improved accuracy and precision. The selected staff must be well skilled to carry out processes such as remote sensing, handling GPS data, stratification, conducting tree measurements which require reading clinometers and a significant amount of information on the project area.

ii) Incentives for farmers to enable them to continue their agricultural practices outside the project boundary - In case the selected project area is agricultural land, farmers may need to be displaced and forced to carry out their activities outside of the conservation area. This means having to start all over again and therefore may require some financial support.

iii) Incentives for workers - This is mandatory for all workers that are part of the project. It adheres to the laws of every country to pay for labour.

iv) Capital for carrying out remote sensing techniques - Remote sensing comprises receiving data from satellites. This method requires certain satellite images which can be bought such as LANDSAT, SPOT, Quickbird. Nonetheless, there are a number of free software available on the internet such as QGIS, GRASS, Interimage, E-foto and gvSIG, among others. Satellite imagery is sold at prices that range from $\$ 5-\$ 3000$ per square kilometre. The prices are dependent on the software package being used and the resolution. However, there are good data available for free, such as LANDSAT 8 OU and Sentinel-2 images.

v) Purchasing equipment for measurements and project boundary delineation - The materials required are: clinometers which cost roughly between $\$ 130-\$ 170$, a GPS which usually ranges between $\$ 150-\$ 400$, measuring tape, survey pegs, compass, markers and data sheets.

vi) Seedlings and fertilizers - Once the species to be grown are selected, funds need to be put aside to buy the fruit and vegetable tree seeds and fertilizer.

vii) Management techniques - The management techniques refer to the additional requirements assessed through stratification of the project area, such as live fencing for silvopastoral practices, fertilizers, irrigation pumps and tillage equipment.

viii) Monitoring techniques - The costs related to monitoring are dependent on the frequencies of measurement. The amounts of carbon stocks present before the implementation of the project determine the measurement frequencies. If the project includes afforestation or reforestation, carbon stocks should be measured annually. 
This may turn out to be more costly as opposed to measuring carbon stocks every 2-3 years in a forest or agroforestry management project.

Based on the funding available, the methods to use and implement in the project can be determined to fit within the specified budget.

\section{Environmental and socioeconomic benefits of fruit and vegetable trees}

The primary reasons for cultivation of fruit and vegetable trees are to increase the potential of carbon sequestration, to mitigate climate change and enhance socioeconomic development. The environmental benefits refer to the non-carbon benefits of various fruit and vegetable tree species and the subsequent advantages to the soil environment through decomposition and nutrient cycling which enhance soil fertility and intensify biodiversity. Furthermore, fruit and vegetable trees have the ability to thrive in varying climatic conditions where forests may be unable to exist. Examples of West African indigenous species are palm trees (Cocos nucifera) which grow in saline salts, baobab trees (Adasonia digitata $L$.) which are capable of surviving dry climate and shea nut tree (Vitalleria paradoxa) found in dry savannah, among others. The addition of carbon sinks to the environment increase the likelihood of mitigating climate change through the sequestration of carbon from the atmosphere.

Along with the environmental benefits of fruit and vegetable tree plantations, the social and economic aspects perform a key role in the determination of what species to grow and where. Fruit and vegetable plantations enhance food security, the livelihoods of rural people and contain vast amounts of nutritional values that are fundamental for a healthy lifestyle. The West African Sahel is an example of where there are a number of fruit and vegetable trees with socioeconomic benefits that can improve the diet and livelihoods of the rural poor. Table 3.1.2 gives a few examples of the environmental, economic and social benefits of domesticated trees in the West African Sahel.

Table 3.1.2: Fruit and vegetable trees that are domesticated in the West African Sahel and their economic and social benefits

\begin{tabular}{|l|l|l|l|l|}
\hline Tree species & Social benefits & Economic benefits & $\begin{array}{l}\text { Environmental } \\
\text { benefits }\end{array}$ & $\begin{array}{l}\text { Price per kg } \\
\text { (CFA) } \\
\text { (1 USD=550 } \\
\text { CFA roughly) }\end{array}$ \\
\hline $\begin{array}{l}\text { Adansonia digitata } \\
\text { L. (Baobab) }\end{array}$ & $\begin{array}{l}\text { Rich in vitamin C, } \\
\text { vitamin A and } \\
\text { protein }\end{array}$ & $\begin{array}{l}\text { Fruit pulp, ropes and } \\
\text { medicines }\end{array}$ & $\begin{array}{l}\text { Carbon } \\
\text { sequestration }\end{array}$ & $\begin{array}{l}\text { 250-500 } \\
\text { FCFA/kg }\end{array}$ \\
\hline $\begin{array}{l}\text { Detarium } \\
\text { microcarpum G. et } \\
\text { Perr. (Detar) }\end{array}$ & $\begin{array}{l}3.2 \mathrm{~g} \text { vitamin C, 4.9 } \\
\text { g protein 64.5 g of } \\
\text { sugar. }\end{array}$ & $\begin{array}{l}\text { Cakes, wood used for } \\
\text { fuel, construction poles } \\
\text { and tool handles. } \\
\text { Seeds used as fragrance }\end{array}$ & $\begin{array}{l}\text { Carbon } \\
\text { sequestration }\end{array}$ & $\begin{array}{l}\text { Cakes sell at 25 } \\
\text { F CFA/kg, fruit } \\
\text { sold at 100 } \\
\text { FCFA/kg }\end{array}$ \\
\hline $\begin{array}{l}\text { Parkia biglobosa } \\
\text { (Nere) }\end{array}$ & $\begin{array}{l}\text { Rich in proteins, } \\
\text { lipids, and } \\
\text { phosphorus, } \\
\text { vitamin C and } \\
\text { carbohydrates. }\end{array}$ & $\begin{array}{l}\text { Fruit pulp, dried seeds, } \\
\text { sold as medicine }\end{array}$ & $\begin{array}{l}\text { Carbon } \\
\text { sequestration, } \\
\text { agroforestry, soil } \\
\text { fertility }\end{array}$ & $\begin{array}{l}\text { Dried seeds sell } \\
\text { for 600 F } \\
\text { CFA/kg, fruit } \\
\text { pulp for 200 F } \\
\text { CFA/kg }\end{array}$ \\
\hline $\begin{array}{l}\text { Tamarindus indica } \\
\text { L. (Tamarind) }\end{array}$ & $\begin{array}{l}\text { High levels of } \\
\text { proteins, } \\
\text { carbohydrates }\end{array}$ & $\begin{array}{l}\text { Snacks, making sauces, } \\
\text { wine, ice cream, drinks, } \\
\text { jam, confectionery, }\end{array}$ & $\begin{array}{l}\text { Carbon } \\
\text { sequestration }\end{array}$ & $\begin{array}{l}\text { Fruit pulp sells } \\
\text { for 400 F CFA/kg }\end{array}$ \\
\hline
\end{tabular}




\begin{tabular}{|c|c|c|c|c|}
\hline Tree species & Social benefits & Economic benefits & $\begin{array}{l}\text { Environmental } \\
\text { benefits }\end{array}$ & $\begin{array}{l}\text { Price per kg } \\
\text { (CFA) } \\
\text { (1 USD }=550 \\
\text { CFA roughly) }\end{array}$ \\
\hline & $\begin{array}{l}\text { and minerals such } \\
\text { as potassium, } \\
\text { phosphorus, } \\
\text { calcium and iron }\end{array}$ & $\begin{array}{l}\text { edible oil, dyes. Wood } \\
\text { used for making tool } \\
\text { handles, furniture, } \\
\text { charcoal and fuelwood }\end{array}$ & & \\
\hline $\begin{array}{l}\text { Vitalleria paradoxa } \\
\text { (Shea nut tree) }\end{array}$ & $\begin{array}{l}\text { High levels of } \\
\text { omega } 6 \\
\text { Beneficial for skin } \\
\text { health }\end{array}$ & $\begin{array}{l}\text { Shea butter. Exported for } \\
\text { use in chocolate products } \\
\text { and by pharmaceutical } \\
\text { companies }\end{array}$ & $\begin{array}{l}\text { Carbon } \\
\text { sequestration. }\end{array}$ & $\begin{array}{l}\text { Shea butter sells } \\
\text { for } 400 \mathrm{~F} \mathrm{CFA} / \mathrm{kg} \\
\text { In } 2004 / 2005 \\
\text { Mali exported } \\
10,000 \text { t of dry } \\
\text { kernel for about } \\
800 \text { million F } \\
\text { CFA }\end{array}$ \\
\hline $\begin{array}{l}\text { Ziziphus mauritiana } \\
\text { (Ber) }\end{array}$ & $\begin{array}{l}\text { Leaves, roots, and } \\
\text { bark used for } \\
\text { medicinal } \\
\text { purposes }\end{array}$ & $\begin{array}{l}\text { Fresh juice, fresh fruit } \\
\text { pulp and dry fruit paste. } \\
\text { Wood used for kitchen } \\
\text { utensils, firewood, } \\
\text { charcoal and handles }\end{array}$ & $\begin{array}{l}\text { Carbon } \\
\text { sequestration, } \\
\text { leaves used for } \\
\text { fodder, } \\
\text { recommended } \\
\text { for planting along } \\
\text { contour lines for } \\
\text { erosion control }\end{array}$ & $\begin{array}{l}\text { Fruit pulp sells } \\
\text { for } 350 \mathrm{~F} \mathrm{CFA} / \mathrm{kg}\end{array}$ \\
\hline
\end{tabular}

Source: Kalinganire et al. 2007

The fruit trees above all grow in the semi-arid landscape of the Sahel and through more sustainable practices, increased plantations and agroforestry domesticated indigenous trees can thrive and create more environmental and socioeconomic benefits.

\section{Institutional frameworks and management schemes}

A framework refers to the basic structure underlying a system or procedure. The successful development of fruit and vegetable trees requires a management scheme or framework involving the cooperation of a number of institutions to enable more sustainable and beneficial agricultural practices targeting the livelihoods of communities.

Primarily, an agroforestry project or fruit and vegetable tree plantation requires adequate planning, measurements and research to come up with a reasonable, more sustainable project proposal to contract funds. This is carried out by institutions such as ICRAF, the International Crops Research Institute for Semi-Arid Tropics (ICRISAT) and United Nations Environment Programme (UNEP), among others. These institutions encourage farmers and other agricultural practitioners to practice sustainable agricultural while also promoting quality of produce, the recommended diet for healthier lifestyles, improvement of livelihoods of communities and the socioeconomic development of the country. Additionally, ICRISAT can offer genetically modified seeds so as to guarantee good quality produce to eradicate food insecurity and enhance nutrients in the diets of communities. The funding required for the projects can be sought from bodies such as The World Bank, Africa Challenge Enterprise Fund, African Development Bank, Concern Universal and Starfish Initiatives among others. 
Devex, an international company, currently has a project which aims to improve the livelihoods of small-scale African farmers by increasing their access to local, regional and international markets. Such companies have expertise and links to international markets. This could help farmers sell their produce to small- and large-scale markets, thus increasing their incomes and improving their livelihoods.

At the national level, forest services and governmental organizations can raise funds under the United Nations Framework Convention on Climate Change (UNFCCC) agreements or bilateral supports. The current REDD+ framework is a channel to invest in biocarbon. Many NGOs (CARE, Bioclimatic, LIVELIHOOD) can access funds for various stakeholders to promote biocarbon.

\section{Monitoring requirements}

Monitoring of carbon pools requires measuring, reporting and verifying (MRV) changes in carbon stocks in the project implementation area. This project is designed to enhance carbon sequestration, therefore changes in all carbon stocks claimed need to be remeasured periodically. This can be done by the re-measurement of marked trees in the permanent selected plots and re-measuring other components as shown below (Brown 2002).

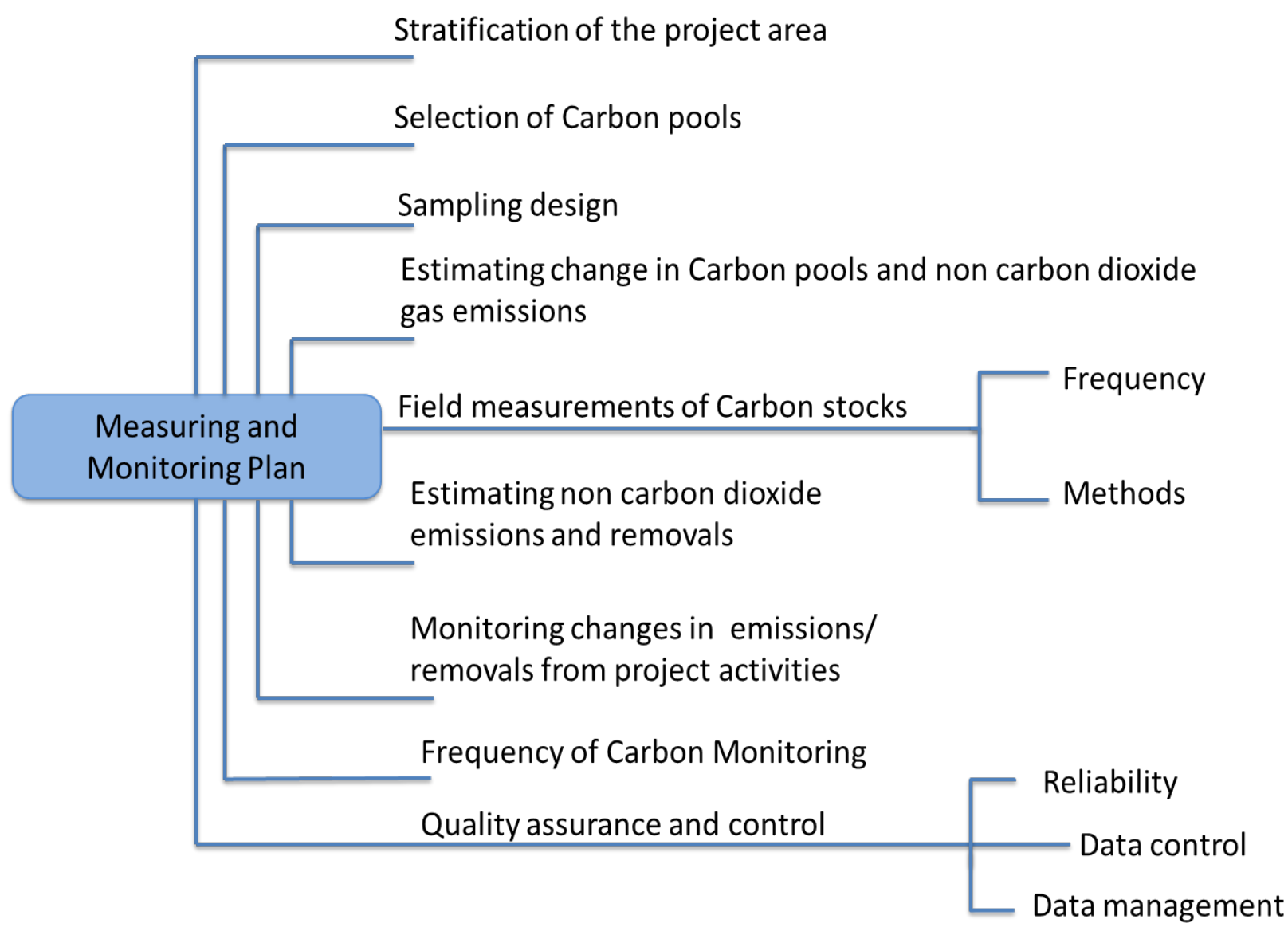

Figure 3.1.3: A measuring and monitoring plan (Source: IPCC 2003) 
The above-ground biomass is monitored through the measurement of the diameter at breast height (DBH), height of the tree and crown cover. The data is then inserted into general allometric equations or species specific allometric equations to assess the increase in carbon stocks since the previous measurements were taken. For a detailed analysis on stratification and measurements see A-2 for the methodology.

Additionally, the impacts of the project on socioeconomic aspects need to be monitored. These can be assessed by handing out surveys to locals and conducting forums to collect feedback on the quality and quantity of fruits and vegetables attained, including their market values and their sales.

\section{Challenges and barriers}

The key purpose of promoting the development of fruit and vegetable trees other than carbon sequestration, is the aptitude of the trees to enhance food security, boost nutritional values in the diets of rural communities, and improve the economic stability of the given regions. Developing countries have been less successful in the implementation of large-scale fruit trees plantation for improved food and nutrition (Mwaniki 2006). This is attributed to the unstable social and political environments that preclude sustainable economic growth, war and civil strife, macroeconomic imbalances in trade and natural resource constraints. Other reasons include poor human resource base, gender inequality, inadequate education, poor health, natural disasters such as floods and locust infestation, and the absence of good governance. All these factors contribute to either insufficient national food availability or insufficient access to food by households and individuals. Some of the barriers and challenges facing the development of fruit and vegetable trees are:

i) Land tenure - Owning the title deed allows the proprietor to determine the fate of the designated project area site. The tenants, women and the landless are less fortunate and are unable to carry out agroforestry practices or plant perennial crops due to lack of land resources, tenure insecurity and crop restrictions (ref to UN-HABITAT concept of secured land use for all). State interventions and conflicts between farmers and pastoralists further limit land tenure security of the rural population. This reduces the willingness of farmers to invest on a longterm basis and to protect natural resources. An example of such a case was noted in Benin (Neef and Heidhues 1994). The fate of the land lies in the hands of the landlord. This causes restrictions in the implementation of fruit and vegetable tree plantation projects or agroforestry as the choice of the possessor may instead lean towards housing.

ii) Adequate funding - Facilitating the successful implementation of a project development programme demands funds that are readily available for all related costs. Insufficient funding hinders the project.

iii) An under-developed agricultural sector - In Africa, the under-developed agricultural sector refers to the poor soil quality, environmental degradation and over-reliance on primary agriculture, among others. Fruit and vegetable production is vulnerable to adverse weather conditions and is therefore a challenge to overcome due to the already continuing global climate change scenario. Additionally, there has been a decline in farm input investments such as fertilizers, seeds and technology adoptions (Mwaniki 2006). 
iv) Diseases, infections and pests - Fruit and vegetable trees can easily be affected by various diseases and infections resulting in reduction in the quality and yield of the species. Particularly, if the disease or infections are unknown and there is no cure, the entire population could be wiped out. Additionally, the occurrences of pests such as locusts and grasshoppers are a menace to fruit and vegetable plantations and must be dealt with quickly.

v) Training workers on measuring and monitoring techniques - A number of workers tend to lack adequate knowledge on sustainable practices, measuring and monitoring techniques. Therefore, it is fundamental to educate them on these practices before implementation of the project.

vi) Environmental constraints - Poor seedling establishment, for example dry seed beds and bad weather.

Challenges and barriers can be easily overcome through adequate planning and strategizing in the pre-project implementation phase.

\section{Capacity development}

There are a number of gaps in capacity development which can be filled with focus on education, research and development, access to capital and infrastructure development. Educating locals on various sustainable farming methods can help the farmers select the most beneficial method.

Africans stepping up and playing an active role in research and development matters which affect them is crucial for bridging the gaps in capacity development. This includes food preservation at the village level, alternative medicines to make health more affordable and accessible to the locals, efficient agricultural extension services, options for improving soil fertility, best approaches for managing the different agricultural systems, and optimal marketing strategies. Care should be taken to modify available technologies to suit the community setting, and not the other way round. For benefits to be realized in all areas, infrastructure development must be a high priority (Mwaniki 2006).

\section{References}

Adria O, Bethge J. 2013. What users can save with energy-efficient cooking stoves and ovens. Wuppertal Institute for Climate, Environment and Energy.

Alforte A, Wilson D, Pulhin F, Lasco R. 2014. Definition of terms. Credits where credits due: A guide to community-level carbon forestry project development. Los Banos, Philippines: World Agroforestry Centre (ICRAF). pxiv-xviii.

Amous S. 1997. The role of wood energy in Africa. WETT Regional Studies, FAO.

Aynekulu E, Vagen T-G, Shepherd K, Winowiecki L. 2011. A protocol for modelling, measurement and monitoring soil carbon stocks in agricultural landscapes. Version 1.1. World Agroforestry Centre, Nairobi.

Bell S. 2001. A beginner's guide to uncertainty of measurement. Measurement Good Practice Guide 11 (2), p3-8.

Brown S. 1997. Estimating biomass and biomass change of tropical forests: A primer. Illinois: Food and Agriculture Organization. p1-55. 
Brown S. 2002. Measuring, monitoring, and verification of carbon benefits for forest-based projects, Philosophical Transactions 360 (1), p1669-1683.

Bugayong L. 2003. Socioeconomic and environmental benefits of agroforestry practices in a community-based forest management site in the Philippines. Available:

http://www.cifor.org/publications/corporate/cd-roms/bonnproc/pdfs/papers/T3 FINAL Bugayong.pdf. Last accessed $5^{\text {th }}$ Jun 2016.

Chave et al. 2014. Improved allometric models to estimate the aboveground biomass of tropical trees. Global Change Biology 20 (1), p3177-3190.

Food and Agriculture Organization. 2010. Managing forests for climate change. Available: http://www.fao.org/docrep/013/i1960e/i1960e00.pdf. Last accessed $5^{\text {th }}$ Jun 2016.

Food and Agriculture Organization. 2016. Wood Energy. Available:

http://www.fao.org/forestry/energy/en/ Last accessed 30 ${ }^{\text {th }}$ August 2016.

Graham S. 1999. Remote sensing. Available:

http://earthobservatory.nasa.gov/Features/RemoteSensing/. Last accessed $11^{\text {th }}$ April 2016.

Guendehou GHS, Lehtonen A, Moudachirou M, Mäkipää R, Sinsin B. 2012. Stem biomass and volume models of selected tropical tree species in West Africa. Southern Forests. 74(2): p77-88.

Henry M, Besnard A, Asante WA, Eshun J, Adu-Bredu S, Valentini R, Bernoux M, Saint-André L. 2010. Wood density, phytomass variations within and among trees, and allometric equations in a tropical rainforest of Africa. Forest Ecol. Manage. 260: p1375-1388. doi:10.1016/j.foreco.2010.07.040.

ICRAF-CGIAR. 2015. Tree functional attributes and ecological database. http://db.worldagroforestry.org/.

ICRAF. 1997. ICRAF Medium Term Plan 1998-2000, Nairobi: ICRAF, 340p.

IPCC. 2013. Climate Change 2013: The Physical Science Basis. Available:

http://www.ipcc.ch/pdf/assessment-report/ar5/wg1/WG1AR5_AnnexIII_FINAL.pdf. Last accessed $18^{\text {th }}$ July 2016.

Kalinganire A, Weber J, Uwamariya A, Kone, B. 2007. Improving rural livelihoods through domestication of indigenous fruit trees in the parklands of the Sahel. Fruit trees. 1 (1), p186197.

Kalinganire A, Weber JC, Uwamariya A, Kone B. 2008. Improving rural livelihoods through domestication of indigenous fruit trees in the parklands of the Sahel. In: Akinnifesi FK, Leakey RRB, Ajayi OC, Sileshi G, Tchoundjeu Z, Matakala P, Kwesiga F (Eds) Indigenous fruit trees in the tropics: domestication, utilization and commercialization. CABI, Oxfordshire, pp 186-203.

Kuyah S, Dietz J, Muthuri C, Jamnadass R, Mwangi P, Coe R, Neufeldt H. 2012. Allometric equations for estimating biomass in agricultural landscapes: I. Above-ground biomass. Agriculture, Ecosystems and Environment. 158, p216-224.

Lal R. 2004. Soil carbon sequestration impacts on global climate change and food security. Science. 304 (1), p1623-1626.

Larwanou M, Yemshaw Y, Saadou M. 2010. Prediction models for estimating foliar and fruit dry biomasses of five Savannah tree species in the West African Sahel. Int. J. Biol. Chem. Sci. 4(6): p2245-2256.

Leakey B, Tchoundjeu Z. 2001. Diversification of tree crops: domestication of companion crops for poverty reduction and environmental services. Experimental Agriculture. 37 (1), p279-296. 
Martin F. 1999. Multipurpose palms you can grow. Available:

http://agroforestry.org/multipurpose-palms-you-can-grow/coconut-palms. Last accessed $18^{\text {th }}$ March 2016.

Moussa M, Mahamane L, Saadou M. 2015. Allometric equations for biomass estimation of woody species and organic soil carbon stocks of agroforestry systems in West African: State of current knowledge. International Journal of Research in Agriculture and Forestry. 2 (10), p17-27.

Mwaniki A. 2006. Achieving food security in Africa: Challenges and issues. Available: http://hqweb.unep.org/training/programmes/Instructor Version/Part 2/Activities/Human Societies/Agriculture/Supplemental/Achieving Food Security in Africa.pdf. Last accessed $25^{\text {th }}$ April 2016.

Nair PKR. 1980. Agroforestry species - A crop sheets manual. ICRAF, Nairobi. 336p. Neef A, Heidhues F. 1994. The role of land tenure in agroforestry: Lessons from Benin. Agroforestry Systems. 27 (2), p145-161.

Pearson T, Walker S, Brown S. 2005. Sourcebook for land use, land-use change and forestry projects. Winrock International and the BioCarbon Fund of the World Bank. p57.

Pearson T, Brown S, Birdsey R. 2007. Measurement guidelines for the sequestration of forest carbon. Delaware: USDA Forest Service. p12-13.

Pearson T, Casarim F, Brown S, Eickhoff G. 2013. Guidelines for stratification for REDD+: Using a national inventory. Available: https://www.climatelinks.org/resources/guidelinesstratification-redd-using-national-inventory. Last accessed $11^{\text {th }}$ April 2016.

Penman J. 2003. Good practice guidance for land use, land-use change and forestry (GPGLULUCF). Available: http://www.ipcc-nggip.iges.or.jp/public/gpglulucf/gpglulucf.html. Last accessed $24^{\text {th }}$ April 2016.

Rabiou H, Bationo BA, Segla KN, Diouf A, Kossi A, Kokutse AD, Radji R, Mahamane A, Kokou K, Sâadou M. 2015. Estimation de volume commercial du bois de Pterocarpus erinaceus Poir. (Fabaceae) dans les zones sahélo-soudaniennes et Soudaniennes du Niger et du Burkina Faso (Afrique de l'ouest). Journal of Applied Biosciences.87: p8131-8143. doi.org/10.4314/jab.v87i1.13.

Ravindranath H, Ostwald M. 2008. Carbon inventory methods - Handbook for greenhouse gas inventory, carbon mitigation and roundwood production projects. Advances in Global Change Research. 29.

Sasson A. 2012. Food security for Africa: an urgent global challenge. Agriculture and Food Security 1 (2), p1-16.

Shibu J. 2009. Agroforestry for ecosystem services and environmental benefits: An overview. Agroforest Systems 76 (1), p1-10.

Sinare H, Gordon L. 2014. Ecosystem services from woody vegetation on agricultural lands in Sudano-Sahelian West Africa. Agriculture, Ecosystems and Environment. 200 (1), p186199.

Thiam S, Sambou B, Mbow C, Guisse A. 2014. Élaboration de modèles allométriques d"Acacia Sénégal L. Willd versez l'analyse du carbone ligneux en milieu sahélien: cas de la zone sylvopastorale au Sénégal. Afrique SCIENCE.10(3): p304-315.

Tchoundjeu Z, Atangana A, Asaah E, Tsobeng A, Facheux C, Foundjem D, Mbosso C, Degrande A, Sado T, Kanmegne J, Mbile P, Tabuna H, Anegbeh P, Useni M. 2008.

Domestication, utilization and marketing of indigenous fruit trees in West and Central Africa. In: Akinnifesi FK, Leakey RRB, Ajayi OC, Sileshi G, Tchoundjeu Z, Matakala P, Kwesiga F (Eds) 
Indigenous fruit trees in the tropics: domestication, utilization and commercialization. $\mathrm{CABI}$, Oxfordshire, pp 171-185.

Tappan G, Cushing M. 2013. West Africa Land Use and Land Cover Trends Project. Available: http://lca.usgs.gov/lca/africalulc/results.php. Accessed $15^{\text {th }}$ April 2016.

Toensmeier E. 2016. Carbon sequestration potentials. In: Jorstad L. The Carbon Farming Solution. Vermont: Chelsea Green Publishing. p29-37.

The World Agroforestry Centre. 2016. The Biocarbon and Rural Development (BIODEV) Programme. Available: http://www.worldagroforestry.org/project/biocarbon-and-ruraldevelopment-biodev. Last accessed $30^{\text {th }}$ August 2016.

Valbuena R, Heiskanen J, Aynekulu E, Pitkänen S, Packalen P. 2016. Sensitivity of aboveground biomass estimates to height-diameter modelling in mixed-species West African woodlands. PLoS ONE 11(7): e0158198. doi:10.1371/journal.pone.0158198.

Vine E, Sathaye J. 2000. The monitoring, evaluation, reporting, verification, and certification of energy-efficiency projects. Mitigation and Adaptation Strategies for Global Change. 5 (2), p189-216.

Zomer R, Trabucco A, Coe R, Place F. 2009. Trees on Farm: Analysis of global extent and geographical patterns of agroforestry. World Agroforestry Centre.

\section{B-2/Protection of standing biomass for emission reduction and carbon sequestration}

\section{Rationale and objectives}

A forest, like any ecosystem, is seen as carbon in various reservoirs. Carbon is found everywhere, from the leaves to the soil. A tropical rain forest can store up to 430 tonnes of carbon per hectare in the above-ground biomass and a degraded savanna down to few tonnes per hectare.

Standing biomass refers to the total biomass of a given area at the present time. The strategic approach to climate change mitigation involves the conservation of carbon stocks through sustainable management practices and increasing the carbon sinks and reducing carbon sources through reforestation and afforestation. Over $90 \%$ of West Africa's original forest is affected by human activities, and what remains is heavily fragmented and degraded by humans (Onadeko et al. 2013), through deforestation to accommodate increasing populations by making room for agricultural expansion and housing. The resultant phenomenon is accelerated climate change through rising emissions of carbon dioxide gas into the atmosphere, loss of biodiversity and certain gene pools. 


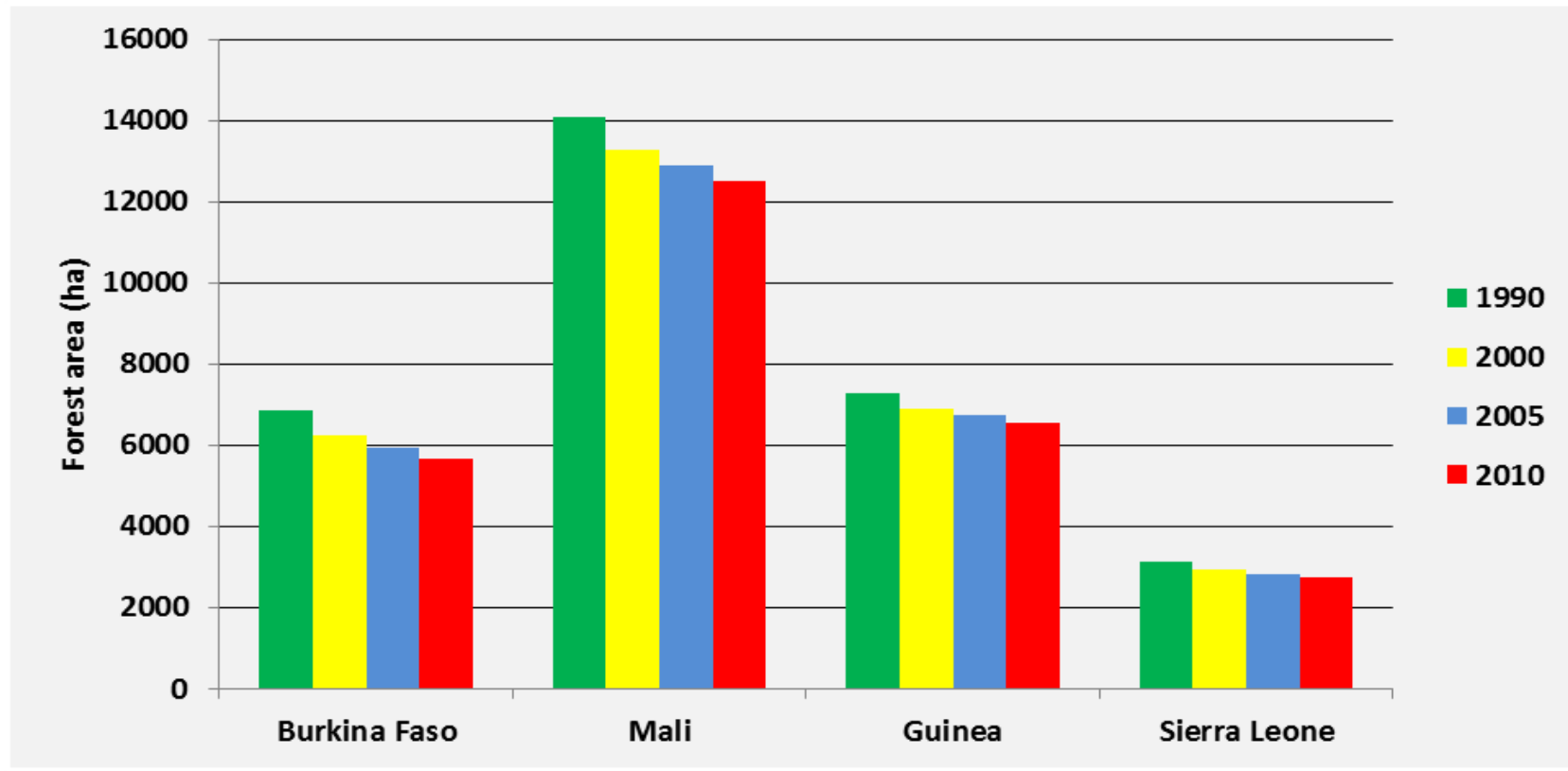

Figure 3.2.1: Change in forested land cover in Burkina Faso, Mali, Guinea and Sierra Leone over the years 1990, 2000, 2005 and 2010 (Source: FAO 2010)

Figure 3.2.1 indicates a subsequent reduction in forested land cover in Burkina Faso, Mali, Guinea and Sierra Leone from 1990 to 2010. The annual deforestation rates/reduction in forest cover are given in the table below.

Table 3.2.1: The annual change rate of forests in Burkina Faso, Mali, Guinea and Sierra Leone

\begin{tabular}{|c|c|c|c|c|c|c|}
\hline \multirow[t]{3}{*}{ Country/area } & \multicolumn{6}{|c|}{ Annual change rate } \\
\hline & \multicolumn{2}{|l|}{$1990-2000$} & \multicolumn{2}{|l|}{$2000-2005$} & \multicolumn{2}{|l|}{ 2005-2010 } \\
\hline & $\begin{array}{l}\text { Percentage } \\
\text { (\%) }\end{array}$ & $\begin{array}{l}1000 \\
\mathrm{ha} / \mathrm{yr}\end{array}$ & $\begin{array}{l}\text { Percentage } \\
\text { (\%) }\end{array}$ & $\begin{array}{l}1000 \\
\mathrm{ha} / \mathrm{yr}\end{array}$ & $\begin{array}{l}\text { Percentage } \\
\text { (\%) }\end{array}$ & $\begin{array}{l}1000 \\
\mathrm{ha} / \mathrm{yr}\end{array}$ \\
\hline Burkina & -60 & -0.91 & -60 & -0.98 & -60 & -1.03 \\
\hline Mali & -79 & -0.58 & -79 & -0.60 & -79 & -0.62 \\
\hline Guinea & -36 & -0.51 & -36 & -0.53 & -36 & -0.54 \\
\hline Sierra Leone & -20 & -0.65 & -20 & -0.68 & -20 & -0.70 \\
\hline
\end{tabular}

Table 3.2.1 shows that the highest reduction in forest cover in all four West African countries was experienced between 2005 and 2010. Standing biomass not only assists in the mitigation of climate change but also has other advantages for local communities and the socioeconomic development of a country. Several species in ecosystems provide local communities with medicines, timber products, food and vital nutrients. Additionally, standing biomass can be incorporated with the development of fruits, vegetables and breeding livestock for agricultural practices such as agrisilvicultural, silvopastoral and agrisilvopastoral. 
Failure to implement appropriate conservation practices may eventually lead to losses in biodiversity and accelerated emissions of carbon dioxide into the atmosphere intensifying climate change. For instance, extensive research on the Guinean rain forest (GRF) in West Africa indicated a reduction in the forest biomass due to expansion of extensive smallholder agriculture. Over 20 years ago, the ecosystem was a global biodiversity hotspot which substantially decreased to $113,000 \mathrm{~km}^{2}$ in the beginning of the millennium, comprising about $18 \%$ of its original area. This subsequently led to emission of approximately 1.4 billion tonnes of $\mathrm{CO}_{2}$ into the atmosphere (Gockowski and Sonwa 2010). Had there been appropriate conservation practices, deforestation and carbon dioxide emissions from the well-known biodiversity hotspot could have been avoided.

Conserving standing biomass not only refers to the prevention of deforestation, but also entails methods of sustainable management for socioeconomic purposes. Examples of methods of conservation include:

a) Fencing - To abolish illegal harvesting of wood by local communities in conserved areas containing endangered species. Fencing is suitable for a small area of land being conserved with endangered species. On the other hand, conserving a large forested area may require locals to use an alternative source, which in a carbon inventory is referred to as leakage.

b) Reforestation - Re-planting trees where they had been cut down, perhaps two or three more in the place of each tree that was logged.

c) Afforestation - Planting trees where there were none. This is beneficial in increasing carbon sequestration as standing biomass is increased.

d) Sustainable harvesting - With sustainable harvesting techniques, locals can derive products such as medicines, timber, fruits and so on, without causing substantial amounts of harm to the conserved area.

e) Sustainable management techniques - Such as pruning and coppicing. The conserved area may also contain dead logs which can be used by local communities as timber or any other preferred purpose. This would ultimately reduce the amount of trees logged.

Activities that increase biomass and carbon sequestration include planting new trees and protecting existing trees. Alternatively, activities that decrease biomass comprise harvesting, fires, deforestation and disturbances (for example, destruction of tree seedlings by wild animals), among others.

For maximum carbon sequestration, it is essential to protect existing biomass which has sequestrated considerable amounts of $\mathrm{CO}_{2}$ from the atmosphere over the years of growth and promote afforestation and reforestation.

\section{Data and information requirements for biomass and carbon}

The carbon stocks in a conservation project can be estimated by:

i) Targeting forested land or ecosystem to carry out conservational practices.

ii) Identifying the conservational practices to be implemented in the area by investigating the type of vegetation and species in the area. 
iii) Measurements for estimating carbon stocks of the region, using methodologies similar to assessing carbon sequestration of fruit and vegetable trees (see A2).

iv) Estimating the production of fuelwood, timber and destructive sampling (if any).

v) Calculating the uncertainty.

vi) Monitoring change in tree carbon stocks over time.

Above-ground biomass is greatly affected by conservation, protection and natural regeneration, and halting the felling of trees. Therefore it is important to estimate and monitor carbon stocks using above-ground biomass values. Additionally, the implementation of projects targeting mitigation of climate change through carbon sequestration, land restoration, afforestation, reforestation and conservation should take into consideration the baseline scenario, additionality, leakage and the project scenario for monitoring purposes. In the case of conserving standing biomass, the expected outcome is given below.

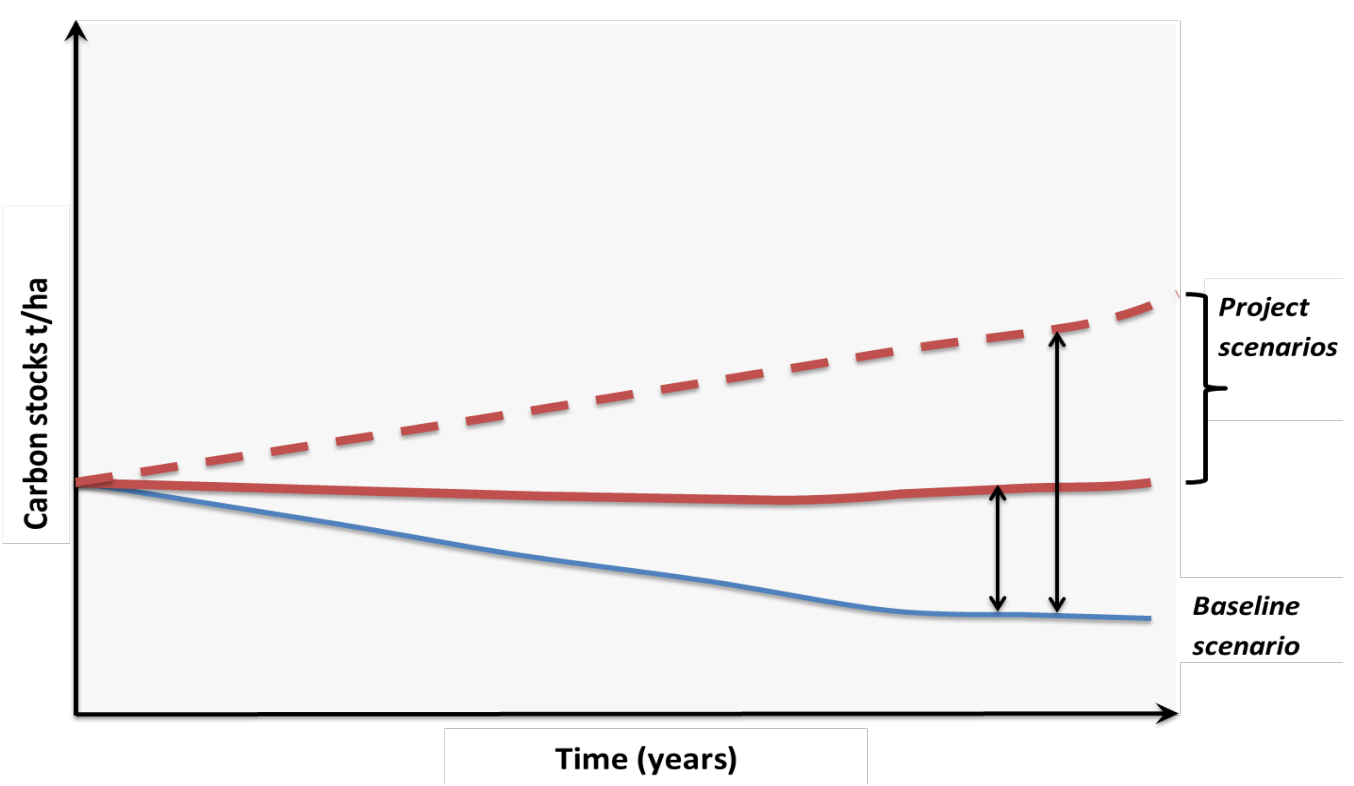

Figure 3.2.2: The graph above illustrates two different scenarios that may take place in the absence of effective conservation resulting in active deforestation in an ecosystem

In an ecosystem which lacks appropriate conservation practices, the baseline scenario (condition of the area before the implementation of the project) depicts a declining trend of carbon stocks. This is as a result of deforestation to create land for agriculture and housing, for timber and for fuel. Adding conservation techniques and imposing a ban on deforestation in the selected area could lead to stable or increasing carbon stocks, consequentially reducing climate change through lessened carbon dioxide emissions (figure 3.2.2) - indicated by a red stable line. The amount of carbon stocks in a forest, before and after project implementation, can be measured and determined in a similar way to that stated and explained in the development for fruit and vegetable trees (figure 3.1.2).

\section{Carbon abatement potential}

The carbon abatement potential regarding the conservation of standing biomass would refer to the amount of carbon stocks present in the selected area before and after project 
implementation. The key purpose of conserving the standing biomass is to avoid deforestation and loss of biomass. Therefore, it is fundamental to ensure carbon stocks are either stable or increasing during every monitoring period. Table 3.2.2 presents examples of some ecosystems and the high amounts of carbon stocks they harbour, revealing the positive significance of enhancing strategies for the conservation of standing biomass.

The estimated amount of carbon sequestered by tropical forests, which form majority of the vegetation in West Africa, is a total of $428 \mathrm{GtC}$ a year. Additionally, the highest carbons stocks were found to be located in the above-ground biomass of the ecosystem (Ravindranath and Ostwald 2008). 
Table 3.2.2: Examples of species found in forests of $W$ Africa and their estimated carbon sequestration potentials ( $\mathrm{t} / \mathrm{ha} / \mathrm{yr}$ )

\begin{tabular}{|l|l|l|l|}
\hline $\begin{array}{l}\text { Species found in the forests of } \\
\text { West Africa }\end{array}$ & $\begin{array}{l}\text { West African } \\
\text { countries }\end{array}$ & $\begin{array}{l}\text { Carbon sequestration } \\
\text { potential (t/ha/yr) }\end{array}$ & References \\
\hline $\begin{array}{l}\text { Eucalyptus camaldulensis } \\
\text { Dehn (Eucalyptus trees) }\end{array}$ & Guinea & $7.80 \mathrm{t} / \mathrm{ha} / \mathrm{yr}$ & $\begin{array}{l}\text { Bordbar and } \\
\text { Mortazavi 2008 }\end{array}$ \\
\hline $\begin{array}{l}\text { Bambusa vulgaris } \\
\text { (Bamboo trees) }\end{array}$ & Ghana & $8-34 \mathrm{t} / \mathrm{ha} / \mathrm{yr}$ & Toensmeier 2016 \\
\hline $\begin{array}{l}\text { Eucalyptus urophylla } \\
\text { (Eucalyptus trees) }\end{array}$ & Côte d'lvoire & $5.52 \mathrm{t} / \mathrm{ha} / \mathrm{yr}$ & Chen et al. 2015 \\
\hline Hevea brasiliensis (Rubber trees) & Nigeria, Ghana & $2 \mathrm{t} / \mathrm{ha} / \mathrm{yr}$ & Toensmeier 2016 \\
\hline
\end{tabular}

There are various references of natural forest carbon potential in the literature that can be referred to in assessing the potential of various ecosystems (FAO statistics).

\section{Costs and investments}

The cost-benefit analysis is an important factor to consider when implementing conservational practices. These analyses indicate whether the aggregate benefits of policy decisions outweigh the costs. Information provided on cost-benefit analyses can help in making efficient decisions about how to best allocate scarce resources in pursuit of various conservational objectives (Naidoo and Ricketts 2006). Before a conservation project is executed, the consequential costs and amount of funding must be outlined and taken into consideration to ensure the benefits of conserving the land offset the costs procured. To estimate a set budget for a conservation project, a number of costs are incurred, relatively similar to those described in $\mathrm{B}-1$ :

i) Training staff - Estimating the relative amount of carbon stocks in an ecosystem involves a subsequent number of measurements, including tree height, diameter at breast height and crown diameter. The workers also need to be proficient in interpreting data obtained from clinometers, GPS systems and satellites.

Additionally, further training may be required for any physical conservational practices being implemented, such as fencing.

ii) Educating local communities and farmers on the importance of conservation and sustainable methods of conservation - This is imperative as deforestation emits carbon dioxide into the atmosphere which is the leading cause of climate change. Hence educating locals on the importance of conservation and various sustainable management practices is fundamental. The costs here are procured in attaining qualified staff to head the informative groups, for transportation, to find a suitable location for the classes and provide some learning materials.

iii) Advertising, talks and forums - Although advertising is costly, it has its pros as it creates awareness on a larger scale. Advertisements on bill boards, notice boards, television and radio networks on the importance of conserving standing biomass and alerting the public on deforestation rates and the resulting consequences. Advertisements can be also useful in fundraising. Additionally, some citizens would alter their lifestyles and attain a more green and sustainable prospect on life by reducing their carbon footprints willingly.

iv) Incentives for workers - This is mandatory for all workers who are part of the project. Incentives can be in various forms, including financial or in-kind benefits, assets and products out of forests. 
v) Paying dividends to farmers beginning sustainable practices - Farmers may need to alter their current agricultural practices to attain more environmentally-friendly agricultural systems which may require abandoning the conservation area. Therefore, farmers must be compensated if this is the case.

vi) Investing in instruments for carbon inventories - These include clinometers, GPS, measuring tapes, survey pegs, compass, markers and data sheets.

vii) Capital for remote sensing techniques - Remote sensing is required for stratification and project delineation and may be costly, but is necessary. Programmes such as LANDSAT and SPOT are widely used to generate satellite images. Alternatively, there are a number of free online satellite imagery programmes such as GRASS, Interimage and E-foto.

viii) Fencing - Opting to fence the area comes at a high cost depending on the perimeter of the land, number of posts, the size of posts and the material the fencing is derived of. Commonly, electric fencing or barbed wire is used, but these may impose dangers for animals in the project area. Moreover, migration of animals is greatly restricted and locals are completely cut off from sources, thus forcing them to fetch their commodities from elsewhere, resulting in leakage. The approximate cost of fencing per foot is $\$ 15-\$ 20$ for barbed wire and $\$ 1-\$ 3$ for electric fencing.

ix) Seedlings and fertilizers - These expenses occur when considering afforestation and reforestation strategies in the conserved area, for the recommended species of trees to grow. Ensure these inputs are available from the shortest distance possible with required quality.

x) Sustainable management techniques - These are the techniques that are implemented in the project area to maintain conservation of the standing biomass and promote sustainable agriculture in the area, if any. Examples are pruning to avoid competition in the area for ground vegetation and coppicing to stimulate growth.

xi) Monitoring of carbon stocks - The estimated expenditure is highly dependent on the frequency of measurements. Carbon stocks in a reforestation or afforestation project must be measured annually to monitor growth carbon sequestration potential of the newly planted trees. On the other hand, a forest conservation project excluding addition of new biomass can be measured every 2-3 years, resulting in less expenses.

Overall, the costs affiliated with the conservation programme must be offset by the benefits achieved environmentally, socially and economically.

\section{Environmental and socioeconomic benefits of conserving standing biomass}

Conserving standing biomass not only benefits the environment by acting as a carbon sink and mitigating climate change, but also devises several social and economic advantages for local communities provided the sources are managed and acquired in a sustainable manner. A few of the sustainable management techniques have been mentioned (see section on rationale and objectives) and following these approaches can greatly benefit the economy and the environment. 
The protection of forests is vastly necessary with the growing amounts of deforestation. Not only do carbon dioxide concentrations in the atmosphere increase, but biodiversity is significantly lost. This in turn affects the livelihoods of local communities who depend on the forest for income as a portion of the lost diversity could be the capital generating source for their families.

To enjoy both environmental and socioeconomic benefits from standing biomass conservation, local communities must carry out sustainable practices, such as obtaining certain medicines, timber, fruits and herbs from harvesting only the part of the trees or plants that bear the required product. Applying the use of coppicing as a management technique is recommended as the chopped tree remains can be used by the community. At the same time, this stimulates growth of trees. Pruning also results in large amounts of twigs and woody stems which are of economic value. These are suitable conservative methods which prominently reduce the logging of the entire tree and promote socioeconomic development simultaneously. Furthermore, dead logs or twigs found in the protected forested area can be used for timber and firewood.

Table 3.2.3 highlights some species found in forests across West Africa that are harvested in sustainable ways, thus benefiting both the environment and socioeconomic development.

Table 3.2.3: Examples of species that are harvested in sustainable techniques across West Africa

\begin{tabular}{|c|c|c|c|c|}
\hline Tree species & Social benefits & $\begin{array}{l}\text { Economic } \\
\text { benefits }\end{array}$ & $\begin{array}{l}\text { Environmental } \\
\text { benefits }\end{array}$ & $\begin{array}{l}\text { Estimated prices } \\
\text { (1 USD=550 CFA } \\
\text { roughly) }\end{array}$ \\
\hline $\begin{array}{l}\text { Dacryodes edulis } \\
\text { (Safou) }\end{array}$ & $\begin{array}{l}\text { High levels of } \\
\text { protein, fibre and } \\
\text { appreciable } \\
\text { amounts of } \mathrm{K}, \mathrm{Ca} \text {, } \\
\mathrm{Na}, \mathrm{Mg} \text { and } \mathrm{P}\end{array}$ & $\begin{array}{l}\text { Fruit pulp, flowers } \\
\text { used in } \\
\text { apiculture, herbal } \\
\text { medicines and } \\
\text { sustainably } \\
\text { harvested wood } \\
\text { can be used for } \\
\text { door handles and } \\
\text { timber }\end{array}$ & $\begin{array}{l}\text { Sustainably } \\
\text { harvested and } \\
\text { environmental } \\
\text { policies } \\
\text { implemented }\end{array}$ & $\begin{array}{l}18-440 \text { CFA with } \\
\text { yield of } 20-50 \mathrm{~kg} \\
\text { per tree }\end{array}$ \\
\hline $\begin{array}{l}\text { Laccosperma } \\
\text { secundiflorum } \\
\text { (Rattan) }\end{array}$ & Furniture & $\begin{array}{l}\text { Furniture, laundry } \\
\text { baskets, shopping } \\
\text { and flower } \\
\text { baskets, serving } \\
\text { trays, dining sets }\end{array}$ & $\begin{array}{l}\text { Sustainable } \\
\text { harvesting and } \\
\text { permission from } \\
\text { district forest } \\
\text { manager required } \\
\text { to carry out any } \\
\text { harvesting }\end{array}$ & $\begin{array}{l}4500-4700 \text { CFA - } \\
\text { approximately } 20 \\
\text { pieces }\end{array}$ \\
\hline $\begin{array}{l}\text { Vitellaria } \\
\text { paradoxa } \\
\text { (shea nut tree) }\end{array}$ & $\begin{array}{l}\text { High levels of } \\
\text { omega } 6 . \\
\text { Beneficial for skin } \\
\text { health }\end{array}$ & $\begin{array}{l}\text { Shea butter and } \\
\text { soap. Exported for } \\
\text { use in chocolate } \\
\text { products and } \\
\text { pharmaceutical } \\
\text { companies }\end{array}$ & $\begin{array}{l}\text { Encouraging } \\
\text { sufficient } \\
\text { incentives to local } \\
\text { people to ensure } \\
\text { the conservation } \\
\text { of rainforest } \\
\text { resources }\end{array}$ & $\begin{array}{l}\text { Shea butter sells } \\
\text { for } 400 \mathrm{CFA} / \mathrm{kg}\end{array}$ \\
\hline
\end{tabular}

Source: CIFOR 2004 


\section{Institutional frameworks and management schemes}

Successful conservation projects are all managed, funded and conducted by a number of institutions following a set framework and policies that are adhered to. Numerous conservation projects in West Africa are coordinated, planned and implemented by organizations such as the International Centre for Forestry Research (CIFOR), ICRAF, the United Nations Environment Programme (UNEP) in conjunction with United Nations Reducing Emissions from Deforestation and forest Degradation (UN-REDD), Sustainable and Thriving Environments for West African Region Development (STEWARD) which concentrates on the upper Guinean forest ecosystems, and The African Conservation Foundation. The roles of these institutions are to conduct conservation-based projects on landscapes experiencing increasing deforestation and protect the biodiversity of both animals and plants species. They also develop project proposals, carry out measurements and frequent monitoring of carbon stocks so as to enhance the livelihoods of surrounding local communities.

Understandably, every project requires a decent amount of funding. It is the role of the institution heading the conservation activities to obtain the finances and required resources by presenting adequate project proposals. These monies can be acquired from establishments such as The World Bank, Africa Challenge Enterprise Fund, Starfish initiatives, African Development Bank, Concern Universal, United States Agency for International Development (USAID) and United States Forest Service/International Programmes (USFS/IP).

As previously mentioned (see B-1: Institutional frameworks), locals can sell their produce through links into international markets by companies such as Devex. Such exposure can substantially improve socioeconomic development. What is superlative about this is that the environment benefits through conservation and sustainable practices while farmers gain their share of advantages.

\section{Monitoring requirements}

This entails the Measuring, Reporting and Verifying (MRVs) of carbon stocks. In a conservation project excluding any reforestation or deforestation, the carbon stocks can be measured every 2-3 years. Carbon stocks for reforestation or afforestation programmes would be expected to be monitored at least every year to observe the effectiveness of the project implementation. Therefore, in a conservation project, carbon stocks are predicted to either remain steady or increase.

In addition to monitoring carbon stocks, the progress of the conservation of standing biomass can also be assessed through direct viewing, remote sensing techniques and surveys. Forums held to obtain information of the advancement of the conservation project from locals in the area are also useful.

\section{Challenges and barriers}

Conservation of standing biomass comes with great amounts of implications, mostly because of the economic value of the resources. However, conserving standing biomass also comprises sustainable management techniques, so farmers are not banned from the resources. This is a common misunderstanding and needs further input and elaboration. 
Some challenges and barriers when conducting a conservation project include:

i) Land tenure - This is one of the biggest challenges only because the forested land required to undergo a conservation project may be entitled to a landholder that wants to use the land for other personal purposes. This would mean that the involved institutions would have to come to a settlement where both parties benefit to create a win-win situation. It could be through paying the titleholder a sum of money every month or investing in new property away from the project conservation area entitled to the landlord.

ii) Adequate funding - Conservation projects come at a high cost and to ensure a successful programme, substantial amounts of capital is required. Herein, the issue is that a number of funding organizations cut back subsidies to assist other global causes and crises at certain periods of time. Therefore, funding may at times be insufficient, resulting in project delays.

iii) Diseases, infections and pests - In a reforestation or afforestation conservation programme the onset of diseases, infections and pests impede the progression of the project. The species to be implanted must therefore be carefully selected.

iv) Educating farmers on sustainable management and harvesting - The knowledge and skills of individual farmers and organizations need to be developed for accurate project implementation.

v) Training labour on measuring and monitoring carbon stocks - Human error is a common, unavoidable fault. However, through sufficient amounts of training these errors can be avoided.

vi) Development of bioenergy - Bioenergy is renewable energy that can substantially reduce carbon dioxide emissions. Acquisition of bioenergy may however come at the expense of the ecosystems such that forests could be cleared to plant more biofuel plantations such as sugarcane and palm oil trees. Additionally, these plantations require larger amounts of land and water to generate high quality yields.

Through defining clear, practical measures of conservation success and developing the skills and knowledge of individuals in organizations the challenges and barriers can be overcome (Salafsky et al. 2006).

\section{Capacity development}

Conservative capacity development encompasses key strategies to combat drawbacks that could affect a project. The main barriers and gaps in conservation initiatives are explored and steps are taken to ensure successful implementation. A number of measures that facilitate conservation capacity building are:

i) Enhanced education and training on sustainability - The aptitude of conservation projects can be improved by bridging the gaps in the quality of training and education the staff and farmers receive. It is fundamental to encourage farmers to start off by growing their produce using sustainable approaches to avoid land use change later which may be more costly.

ii) Advanced conservation methods - Further research and initiation of workshops on up-to-date conservation tools and techniques, which could possibly make the project more sustainable and considerably easier to execute.

iii) Suitable marketing strategies - Through sustainable harvesting techniques, delivering appropriate marketing strategies to the farmers, depending on the 
produce, would in turn allow them to receive higher income with better quality yield. Therefore, farmers would support the idea of sustainable harvesting and conservation provided the economic benefits are plenty.

\section{References}

Bordbar K, Mortazavi M. 2008. Carbon sequestration potential of Eucalyptus Camaldulensis Dehnh. and Acacia Salicina Lindl. plantation in western areas of Fars Province. PajouheshVa-Sazandegi. 19 (1), p95-103.

Brander M. 2012. Greenhouse Gases, $\mathrm{CO}_{2}, \mathrm{CO}_{2} e$, and carbon: What do all these terms mean? Available: http://ecometrica.com/assets/GHGs-CO2-CO2e-and-Carbon-What-Do-TheseMean-v2.1.pdf. Last accessed $2^{\text {nd }}$ June 2016.

Centre for International Forestry Research. 2004. Fruits and oils, wood carving and wood products, fibres and weaving materials. In: Sunderland T, Ousseynou N. Forest Products, Livelihoods and Conservation. $2^{\text {nd }}$ ed. Indonesia: Centre for International Forestry Research. p91-291.

Chen Y, Liu Z, Rao X, Wang X, Liang C, Lin Y, Zhou L, Cai X, Fu S. 2015. Carbon storage and allocation pattern in plant biomass among different forest plantation stands in Guangdong, China. Forests. 6 (1), p795-805.

Climate Change Connection (CCC). 2014. $\mathrm{CO}_{2}$ equivalents. Available:

http://climatechangeconnection.org/emissions/co2-equivalents/. Last accessed $2^{\text {nd }}$ June 2016.

Food and Agriculture Organization. 2010. Global Forest Resources Assessment 2010. Rome: FAO.

Gockowski J, Sonwa D. 2010. Cocoa intensification scenarios and their predicted impact on $\mathrm{CO}_{2}$ emissions, biodiversity conservation, and rural livelihoods in the Guinea Rain Forest of West Africa. Environmental Management. 48, p307-321.

MacDicken KG. 1997. A guide to monitoring carbon storage in forestry and agroforestry projects. Winrock International, Arlington, VA, USA, $87 \mathrm{pp}$, available at:

http://www.winrock.org/REEP/PDF_Pubs/carbon.pdf; also in Spanish from Fundacion Solar, Guatemala, http://www.winrock.org/REEP/PDF_Pubs/fundacionsolar.pdf.

Naidoo R, Ricketts T. 2006. Mapping the economic costs and benefits of conservation. PLOS biology. 4 (11): e360. doi:10.1371/journal.pbio.0040360.

OECD. 2001. Carbon dioxide equivalent. Available:

https://stats.oecd.org/glossary/detail.asp?ID=285. Last accessed $2^{\text {nd }}$ June 2016.

Onadeko A, Egonmwan R, Saliu J. 2013. Biodiversity change: Preliminary monitoring of Anura species in selected vegetation sites in southwestern Nigeria. West African Journal of Applied Ecology. 21 (1), p70-82.

Ravindranath N, Ostwald M. 2008. Carbon inventory methods. Switzerland: Springer. p16147.

Salafsky N, Margoluis R, Redford K, Robinson J. 2002. Improving the practice of conservation: A conceptual framework and research agenda for conservation science. Conservation Biology. 16 (6), p1469-1479.

Sebukeera C, Muramira E, Momokama C, Elkholei A, Elbagouri I, Masumbuko B, Rabesahala V. 2006. Forests and woodlands. In: Jennifer C, Katerere M. Africa Environment Outlook 2. Nairobi: United Nations Environment Programme. p196-223.

Subedi B, Pandey S, Pandey A, Rana E, Bhattarai S, Banskota T, Charmakar S, Tamrakar R. 2010. Forest carbon stock measurement. Nepal: Asia Network for Sustainable Agriculture 
and Bioresources, Federation of Community Forest Users Nepal, International Centre for Integrated Mountain Development. p2-43.

Toensmeier E. 2016. Carbon sequestration potentials. In: Jorstad, L. The Carbon Farming Solution. Vermont: Chelsea Green Publishing. p29-37.

UNEP. 2006. GEO Africa Data Portal. United Nations Environment Programme. Available: www.unep.org/geo/data/africa. Last accessed 22 ${ }^{\text {nd }}$ May 2016. 


\section{B-3/Nitrogen-fixing trees and soil fertilization}

\section{Rationale and objectives}

Nitrogen fixation is a process by which nitrogen $\left(\mathrm{N}_{2}\right)$ from the atmosphere is converted into ammonia $\left(\mathrm{NH}_{3}\right)$, a free form that can be used by plants, animals and micro-organisms to manufacture amino acids, proteins, nucleic acids and other nitrogen-containing components necessary for life. This process is mediated in nature by $\mathrm{N}$-fixing rhizobia bacteria

(Rhizobiaceae, $\alpha$-Proteobacteria) (Sørensen and Sessitsch 2007). In legumes and a few other plants, the rhizobia bacteria are present in small nodules found on the roots that convert the nitrogen to ammonia which is then absorbed by the plants.

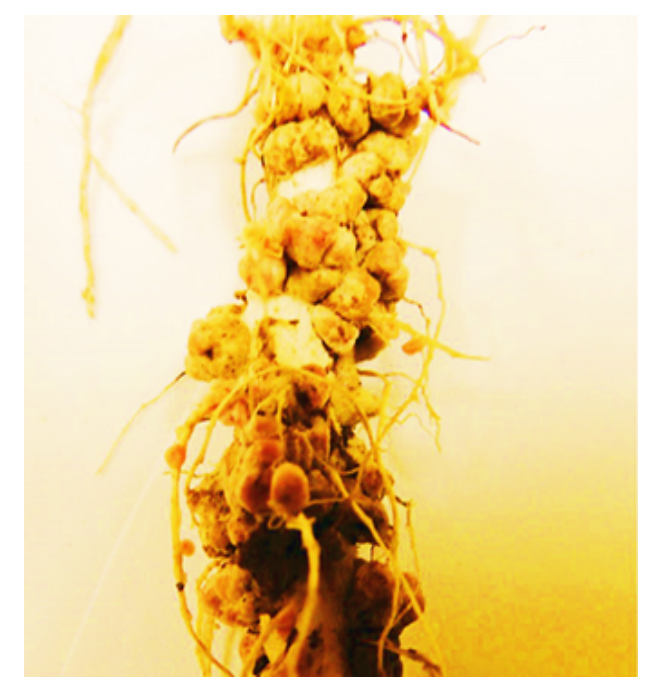

Figure 3.3.1: A legume plant root containing nodules where the nitrogen-fixing bacteria is present (Source: Lindemann and Glover 2015)

Other than bacteria-filled nodules present on selected plant and tree species, biological nitrogen fixation takes many other forms in nature including blue-green algae, lichens and free-living soil bacteria. These nitrogen-fixing techniques contribute significant amounts of ammonia to natural ecosystems (but not cropping systems) to generate biomass. However, further research has indicated that nitrogen fixation by leguminous plants and trees is much higher ranging from about 25-75lb per acre per year in natural ecosystems. It is even higher in cropping systems as opposed to $5 \mathrm{lb}$ per acre per year by the alternative biological nitrogen-fixing methods (Lindemann and Glover 2015, Frankow-Lindberg and Dahlin 2013, Guldan et al. 1996, Burton 1972).

However, it is important to note that not all plants are efficient in converting nitrogen into ammonia and therefore require additional nitrogen application in the form of fertilizers. Common beans are poor fixers of nitrogen and usually convert less than their actual nitrogen needs. For maximum yield, an extra 30-50lb of nitrogen fertilizer per acre needs to be applied. However, if the beans are not nodulated the yield may still remain low as research has suggested that the nodules also enhance the efficient use of fertilizer (Lindemann and Glover 2015). 
Nitrogen-fixing plant species may respond more positively to elevated atmospheric carbon dioxide concentrations than other species because of their ability to maintain a high internal nutrient supply (Temperton et al, 2003). Alnus glutinosa (alder trees) grown in elevated levels of carbon dioxide illustrated a significant increase in nitrogenase activity and smaller more numerous, less clumped root nodules. These smaller nodules enhance the surface area, thereby increasing the nitrogen-fixing capacity (King and Purcell 2001, Temperton et al. 2003) which in turn increases the carbon sequestration. Additionally, root nodules of unfertilized alder trees growing in elevated carbon dioxide conditions had a larger biomass compared to unfertilized trees growing in ambient settings. These results indicate a subsequent dependence of nitrogen fixation in plants on carbon dioxide levels. Moreover, the data depicts exactly how important nitrogen-fixing trees can be for carbon sequestration and mitigating climate change.

An example of a widely planted nitrogen-fixing species in Africa is the Faidherbia albida which is usually found in parklands. It has a unique compatibility with cropping systems due to its 'reverse leaf phenology' - it is dormant during the wet season and drops its leaves to fertilize associated crops through leaf litter decomposition. Its leaves only grow during the dry season and provide nutritious livestock fodder during critical periods of drought. Additionally, the F. albida contributes significantly to maintaining crop yield through the biological nitrogen fixation and favourable microclimate while minimizing tree competition (Verchot et al. 2005). Other examples of nitrogen-fixing species across West Africa are Albizzia lebbek, Acacia auriculiformis and Gliricidia sepium, among others.

The addition of fertilizers to soil similarly results in increased carbon sequestration and higher biomass production. This is because the most commonly used fertilizers contain relative amounts of Nitrogen, Phosphorus and Potassium (NPK fertilizers) for optimum yield production. However, if fertilization is not well managed, excess amounts of nitrogen can result in deterioration of crop residue instead of increasing the biomass through the process of photosynthesis by sequestrating carbon dioxide from the atmosphere. Nitrate pollution of ground and surface water, soil quality degradation and increased carbon dioxide offset are consequences of excess nitrogen fertilization (Khan et al. 2007). Therefore, nitrogen fertilization should be managed by site-specific assessment of soil nitrogen availability to avoid surplus soil nitrogen (Khan et al. 2007).

The key objective of planting nitrogen-fixing trees and soil fertilization is to allow maximum carbon sequestration to mitigate climate change. The trees also create appropriate shading for smaller crops and help control soil erosion. Decomposed leaf litter and twigs from nitrogen-fixing species enhance fertility of soils resulting in better quality produce. A number of nitrogen-fixing trees have economic value from timber and medicinal use. The $F$. albida can grow in dry climates increasing soil fertility of the area and increasing biomass production which results in reduced carbon dioxide in the atmosphere and in turn reducing the effects of climate change.

In agroforestry, plantations, home gardens and forests, fertilization and nitrogen-fixing trees can be utilized to enhance the quality and yield of the produce while simultaneously helping the environment. Therefore, the communities and environment benefit greatly, provided sustainable management techniques are applied. 


\section{Data and information requirements for carbon sequestration by nitrogen-fixing}

\section{trees and soil fertilization}

Assessing carbon stocks in nitrogen-fixing trees and fertilized trees can be done by measuring the relative changes and amount of carbon in above-ground biomass. A similar procedure to that of estimating carbon stocks in fruit and vegetable trees and standing biomass is followed as shown below:

i) First, target the land for project implementation.

ii) Identify the ecosystem practices and species of trees in the area.

iii) Conduct research to estimate the amount of nitrogen in the soil of the selected ecosystem before planting nitrogen-fixing trees and fertilizer. This is because excess amounts of nitrogen can cause nitrate pollution of surface and ground water, soil deterioration, destroy crops and ultimately lead to offset of carbon dioxide emissions.

iv) Estimate the amounts of carbon stocks in the area before project implementation.

v) Select the species of nitrogen-fixing trees to grow and fertilizer to apply (if nitrogen is not adequate).

vi) Estimate the number of trees and amount of fertilizer to add.

vii) Calculate the uncertainty.

viii) Monitor carbon stocks every year to assess progress.

In the case of nitrogen-fixing trees and fertilizer application in a project scenario, the stocks of carbon are predicted to increase unless the nitrogen in the soil is in excess amounts which may cause a contrasting result. The predicted carbon stocks in a baseline scenario and project scenario are shown in figure 3.3.2.

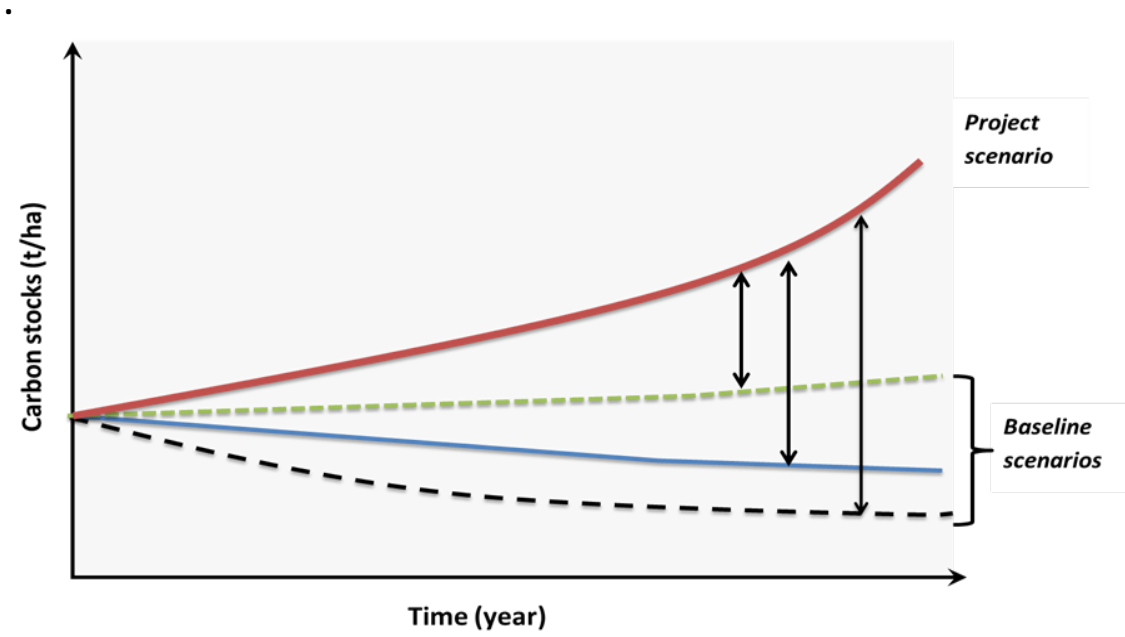

Figure 3.3.2: The graph above illustrates additional carbon sequestration denoted by $A$, B and C, through the implementation of a project scenario to three varying baseline scenarios (see figure 3.2.2)

The selected area for project implementation may either have carbon stocks that are readily increasing with time through natural regeneration (A), steady carbon stocks $(B)$ or reducing carbon stocks $(C)$. However, nitrogen-fixing trees and fertilizer application greatly increases the sequestration of carbon and also contain the leakage, permanence and additionality aspect of every project development protocol. Remote sensing, field measurements and 
modelling can be used to measure the biomass in the baseline scenario and monitoring phases (see A-2).

\section{Carbon abatement potential}

The carbon abatement potential of nitrogen-fixing trees and fertilization is relatively high and has positive effects on the soil and vegetation of the ecosystems. A few examples of the carbon sequestration potential of nitrogen-fixing species are given in table 3.3.1.

Table 3.3.1: Carbon sequestration potentials of nitrogen-fixing trees in West Africa

\begin{tabular}{|l|l|l|}
\hline Species & Carbon sequestration (t/ha/yr) & References \\
\hline $\begin{array}{l}\text { Faidherbia albida (evergreen } \\
\text { agriculture) }\end{array}$ & $2-4 \mathrm{t} / \mathrm{ha} / \mathrm{yr}$ & Toensmeier 2016 \\
\hline $\begin{array}{l}\text { Leucaena leucocephala (White } \\
\text { leadtree) }\end{array}$ & $19.81 \pm 0.44 \mathrm{t} / \mathrm{ha} / \mathrm{yr}$ & Sheikh et al. 2015 \\
\hline $\begin{array}{l}\text { Dalbergia sissoo Rox. } \\
\text { (Rosewood) }\end{array}$ & $27.35 \pm 0.19 \mathrm{t} / \mathrm{ha} / \mathrm{yr}$ & Sheikh et al. 2015 \\
\hline $\begin{array}{l}\text { Pterocarpus lucens } \\
\text { (Padauk) }\end{array}$ & $0.325 \mathrm{t} / \mathrm{ha} / \mathrm{yr}$ & Ngom et al. 2014 \\
\hline
\end{tabular}

Nitrogen-fixing species are often grown in various ecosystems and sometimes mixed with other nitrogen-fixing species to enhance carbon sequestration. Examples of ecosystems containing nitrogen-fixing species and their carbon sequestration potentials are given in table 3.3.2.

Table 3.3.2: Carbon sequestration of some agroforests containing nitrogen-fixing species in West Africa

\begin{tabular}{|l|l|l|l|l|}
\hline Agroforestry systems & Country & $\begin{array}{l}\text { Ages } \\
\text { (yrs) }\end{array}$ & $\begin{array}{l}\text { C (MgCha- } \\
\mathbf{1} \text { yr-1) }\end{array}$ & Authors \\
\hline $\begin{array}{l}\text { Fodder banks (Gliricidia septum, } \\
\text { Pterocarpus lucens and P. erinaceus) }\end{array}$ & Mali & 7.5 & 0.29 & $\begin{array}{l}\text { Takimoto et al. } \\
(2008)\end{array}$ \\
\hline $\begin{array}{l}\text { Hedges (Acacia nilotica, Acacia } \\
\text { senegal, Bauhinia rufescens, Ziziphus } \\
\text { mauritiana and Lawsonia inermis) }\end{array}$ & Mali & 8 & 0.59 & $\begin{array}{l}\text { Takimoto et al. } \\
(2008)\end{array}$ \\
\hline $\begin{array}{l}\text { Parklands (Faidherbia albida and } \\
\text { Vitellaria paradoxa) }\end{array}$ & Mali & 35 & 1.09 & $\begin{array}{l}\text { Takimoto et al. } \\
(2008)\end{array}$ \\
\hline \begin{tabular}{l} 
Culture alley (Leucaena) \\
\hline
\end{tabular}
\end{tabular}

Source: Moussa et al. 2015

Sheikh et al. (2015), conducted research on the carbon sequestration potential of two nitrogen-fixing species, namely Dalbergia sissoo Rox. and Leucaena leucocephala. They found that carbon sequestration was highest when both nitrogen-fixing species were grown together in the same ecosystem. Therefore, planting a number of nitrogen-fixing species together may be highly beneficial in mitigating climate change, increasing soil fertility and producing better quality yield.

Furthermore, adding nitrogen fertilizer in the correct amounts to the soil would increase yield and carbon sequestration in the same way nitrogen-fixing trees would, although excess fertilizer should be avoided to prevent nitrate pollution. Therefore, planting nitrogen-fixing species is recommended, rather than use nitrogen fertilizers in excess to attain the required yield. 


\section{Costs and investments}

Every carbon sequestration project has a set number of expenses and investments to adhere to, to enable a successful and reliable carbon sequestration plan. The following are the costs and investments procured in the case of planting nitrogen-fixing trees and fertilizer application:

i) Training the staff - The workers need to be qualified to conduct accurate tree measurements, interpret GPS data and remote sensing data, carry out stratification and read and use instruments such as clinometers and measuring tapes precisely to avoid human error.

ii) Incentives for workers - Funding must be enough to pay sufficient amounts of labour to every worker.

iii) Dividends for farmers to enable them to continue their agricultural practices outside the project boundary - Depending on the nature of the ecosystem, farmers may need to stop practices such as livestock farming and crop farming to enable the planting of nitrogen-fixing trees so as to restore soil fertility and increase carbon sequestration. This may require the farmers to move out of the project plot and carry out their practices elsewhere using sustainable methods.

iv) Laboratory analysis for estimating the amounts of nitrogen in the soil of the project area - This must be carried out to guarantee that nitrogen levels are not high. This could be disastrous if further nitrogen is added to the soils causing nitrate surface water and ground pollution, soil deterioration, crop die back and offset of $\mathrm{CO}_{2}$ emissions.

v) Capital for carrying out remote sensing techniques - Conducting remote sensing is fairly costly depending on the image quality, size, software and exactly how recent the processed image of the plot is. However, costs can be reduced by using free remote sensing software found online; examples are Quantum GIS, E-foto, GRASS and Inter-image.

vi) Obtaining equipment and materials for measurements and project boundary delineation - For materials required see A-2.

vii) Seedlings and fertilizers - Planting nitrogen-fixing trees and applying nitrogen fertilizers come at a cost and therefore a certain amount of funding must be reserved for these expenses. Nitrogen fertilizers may need to be applied frequently; these costs must also be taken into consideration.

viii) Management techniques - These are the practices applied to the project area to enable socioeconomic benefits through sustainable management such as pruning, coppicing, agrosilviculture, fertilizers and irrigation pumps, among others.

ix) Monitoring methods - The costs incurred here depend on how frequently the carbon stocks of the ongoing project should be monitored. In the case of planting nitrogen-fixing trees and fertilization, the carbon stocks need to be monitored more frequently as opposed to conservation projects.

x) Educating locals and farmers on the benefits of nitrogen-fixing trees and use of nitrogen fertilization - Qualified and skilled staff are required to conduct forums to educate locals and farmers on the environmental and socioeconomic benefits of nitrogen-fixing trees and fertilization. Additionally, farmers and local communities must also be warned on the adverse effects of excess use of nitrogen fertilizers. The expenses are incurred in attaining qualified staff to head the informative 
groups, transportation, finding a suitable location for the classes, providing some learning materials and so on.

\section{Environmental and socioeconomic benefits of nitrogen-fixing trees and fertilization}

The environmental and socioeconomic benefits of planting nitrogen-fixing trees and fertilization are substantial. This is because the nitrogen-fixing trees can be planted in a vast number of ecosystems and can grow in dry lands. Fertilizers can also be applied to a number of plantation sites to increase the quality and yield of crops and plants.

A sufficient number of studies have postulated an increase in carbon sequestration and biomass through the planting of nitrogen-fixing trees and fertilizer application. King and Purcell (2001) and Temperton et al. (2003) found that the nodules in the alder trees increased their surface area in elevated levels of carbon dioxide so as to increase nitrogenfixing capacity. This in turn leads to enhanced carbon sequestration as the biomass of the tree and plant grows. Therefore, nitrogen-fixing trees and fertilizer when grown or applied in an agroforest or any other ecosystem could sequester even larger amounts of carbon dioxide from the atmosphere resulting in the reduction of climate change.

Nitrogen-fixing trees and fertilizer enhance the quality and yields of fruit and vegetable trees, cash crops, herbs and other standing biomass. Therefore, farmers would be able to harvest required part of the plant or tree at larger yields and attain more capital by selling better quality produce. For instance, shea butter that sells at a price of $400 \mathrm{CFA} / \mathrm{kg}$ (USD 0.550 ) could be sold at a higher price provided the yield is of better quality. Additionally, more kilograms of shea butter could be sold at a certain time generating a higher income.

\section{Institutional frameworks and management schemes}

A sufficient amount of planning is required to implement a carbon sequestration project. Herein, a great deal of research is required. These include the effects of nitrogen-fixing species and fertilizer application on various ecosystems and which plantations, forests or home gardens would benefit from nitrogen addition to the soils. Also important is the amount of nitrogen already present in the soils, and which species of nitrogen-fixing trees to plant. These evaluations, including a project proposal and cost estimation for the project can be prepared by organizations such as ICRAF, UNEP and ACF.

Additionally, these institutions can source the funding needed from organizations mentioned in B-1. Ultimately, through sustainable management techniques and using alternative measurement methods, costs can be reduced.

Through planting nitrogen-fixing trees and applying fertilizer, the quality and yield of the produce would greatly increase. Through companies such as Devex which have access to international markets, local communities and farmers would benefit.

\section{Monitoring requirements}

Monitoring requirements are constituted by Measuring, Reporting and Verifying (MRV). Carbon stocks and socioeconomic development are monitored. To estimate the aboveground biomass of the trees and surrounding vegetation, refer to A-2 for a detailed 
explanation on materials required, alternative and cheaper methods of conducting measurements of trees, stratification process, sampling methods and allometric equation modelling using destructive sampling for specific species if there are no equations available. Moussa et al. (2015) presented a list of species specific allometric equations derived from West Africa, some of which outlined below.

Table 3.3.3: Species specific allometric equations of nitrogen-fixing vegetation in West Africa ()

\begin{tabular}{|l|l|l|l|}
\hline Species & Equation & Country & Reference \\
\hline Acacia senegal & $\begin{array}{l}\mathrm{y}=0.032 \mathrm{Dbh}^{3}-1.016 \mathrm{Dbh}^{2}+ \\
10.87 \mathrm{Dbh}+7.429\end{array}$ & Senegal & Thiam et al. 2015 \\
\hline $\begin{array}{l}\text { Faidherbia } \\
\text { albida }\end{array}$ & $\mathrm{y}=7.985 \mathrm{Dbh}+32.277$ & Niger & Larwanou et al. 2010 \\
\hline $\begin{array}{l}\text { Pterocarpus } \\
\text { erinaceus }\end{array}$ & $\mathrm{Vf}=3.024 \mathrm{D} 2.259$ & Niger & Rabiou et al. 2015 \\
\hline $\begin{array}{l}\text { Guiera } \\
\text { senegalensis }\end{array}$ & $\begin{array}{l}\log 10 \mathrm{y}(\mathrm{g})= \\
(0.55+(1.89 \times \log (\mathrm{X}))) \times 10^{\wedge}(-3)\end{array}$ & $\begin{array}{l}\text { Tongomay el } \\
\text { (Burkina Faso) }\end{array}$ & Henry et al. 2011 \\
\hline
\end{tabular}

Source: Moussa et al. 2015

The allometric equations above can be used to determine the carbon stocks in the nodulated nitrogen-fixing trees or shrubs after retrieving the appropriate measurements required and inserting them into the biomass equations (see A-2). Alternatively, Chave et al. (2014) published a more generic equation that can be used to estimate carbon stocks in a wide range of ecosystems. Thus, the surrounding biomass around the nitrogen-fixing trees and the trees that are fertilized can be analysed using a generic equation.

The socioeconomic impacts of growing nitrogen-fixing trees and fertilizer can be assessed through direct viewing of biomass/fruits and vegetables, conducting surveys among farmers and locals to keep track of the quantity and quality of produce, and assessing the nutritional and market value for increased income due to better produce.

\section{Challenges and barriers}

Every carbon sequestration project has some hindrances to overcome to ensure a sustainably managed, well thought-out, successful project. A few of the common challenges and barriers are:

i) Land tenure - Principally, the fate of the land selected for the project implementation is dependent on the plans of the titleholder. The owner may have other personal proposals for development of the land.

ii) Select land that meets the project criteria - This means that the soil of the chosen plot must not be high in nitrogen levels, as adding more nitrogen can have a devastating effect that may take years to undo.

iii) Adequate funding - Without sufficient amount of capital from donors, the project may come to a halt.

iv) Diseases, insects and pests - All plants and trees are susceptible to attack from diseases, pests and insects and this may be a threat to the project as substantial amounts of biomass could be destroyed.

v) Farmers and locals may apply too much fertilizer - Training and education for farmers and local communities on the type of nitrogen-fixing species to grow and 
the correct amounts and types fertilizers is fundamental as too much nitrogen can be destructive to soils and plants.

vi) Requirement of well skilled labour - Carrying out carbon inventories is an intrinsic task therefore workers employed must be well trained and suited for the jobs to minimize human error.

\section{Capacity development}

Capacity development and success of the project can be enhanced by targeting the challenges and barriers that impede the progress of carbon sequestration projects. The most beneficial methods of capacity building are by creating awareness of the importance of nitrogen-fixing trees and fertilization in carbon sequestration. Also important is the advancement of training and education on conducting carbon inventories so as to achieve the most accurate results. Promoting sustainable management techniques such as coppicing and pruning, and establishing a broader market where farmers can sell their produce and in turn gain higher incomes is essential. Sustainable management methods also benefit the environment. Capacity building should focus on the environment and socioeconomic development of a country.

\section{References}

Burton JC. 1972. Nodulation and symbiotic nitrogen fixation. In: Hanson CH (Ed), Alfalfa Science and Technology (Monograph 15; pp.229-246). Madison, WI: American Society of Agronomy.

Frankow-Lindberg BE, Dahlin AS. 2013. $\mathrm{N}_{2}$ fixation, $\mathrm{N}$ transfer, and yield in grassland communities including a deep-rooted legume or non-legume species. Plant and Soil, 370, 567-581.

Guldan SJ, Martin CA, Cueto-Wong J, Steiner RL. 1996. Interseeding legumes into Chile: Legume productivity and effect on Chile yield. HortScience, 31, 1126-1128.

Henry M, Picard N, Trotta C, Manlay RJ, Valentini R, Bernoux M, Saint-André L. 2011. Estimating tree biomass of sub-Saharan African forests: a review of available allometric equations. Silva Fennica. 45(3B): 477-569.

Khan S, Mulvaney R, Ellsworth T, Boast C. 2007. The myth of nitrogen fertilization for soil carbon sequestration. Environmental Quality. 36 (1), p1821-1832.

King CA, Purcell LC. 2001. Soybean nodule size and relationship to nitrogen fixation response to water deficit. Crop Sci. 41: 1099-1107.

Lal R. 2005. Forest soils and carbon sequestration. For. Ecol. Manage. 220. 242-258. Landon JR (Ed) 1991. Booker tropical manual. A handbook for soil survey and agricultural land evaluation in the tropics and subtropics. London: Longman.

Larwanou M, Yemshaw Y, Saadou M. 2010. Prediction models for estimating foliar and fruit dry biomasses of five Savannah tree species in the West African Sahel. Int. J. Biol. Chem. Sci. 4(6): p2245-2256.

Lindemann W, Glover C. 2015. Nitrogen fixation by legumes. Available: http://aces.nmsu.edu/pubs/ a/A129/Last accessed $22^{\text {nd }}$ May 2016.

Moussa M, Mahamane L, Saadou M. 2015. Allometric equations for biomass estimation of woody species and organic soil carbon stocks of agroforestry systems in West African: State of current knowledge. International Journal of Research in Agriculture and Forestry. 2 (10), p17-27. 
Ngom D, Agbangba EC, Fall T, Diatta S, Akpo LE. 2014. Quantification of ecosystem services provided by Pterocarpus lucens Lepr. Ex Guill. and Perrott.: Forage production, timber and carbon sequestration in the biosphere reserve of Ferlo (Northern Senegal). American Journal of Plant Sciences, 2014,5. p766-777. doi.org/10.4236/ajps.2014. 55091.

Rabiou H, Bationo BA, Segla KN, Diouf A, Kossi A, Kokutse AD, Radji R, Mahamane A, Kokou K, Sâadou M. 2015. Estimation de volume commercial du bois de Pterocarpus erinaceus Poir. (Fabaceae) dans les zones sahélo-soudaniennes et Soudaniennes du Niger et du Burkina Faso (Afrique de l'ouest). Journal of Applied Biosciences. 87:p8131-8143. doi.org/10.4314/jab.v87i1.13.

Robledo C, Kanninen M, Pedroni L. 2005. Tropical forests and adaptation to climate change: In search of synergies. Indonesia: Centre for International Forestry Research. p103-116.

Sheikh M, Kumar M, Todaria N. 2015. Carbon sequestration potential of nitrogen-fixing tree stands. Forestry Studies, 62 (1), p39-47.

Sørensen J, Sessitsch A. 2007. Plant-associated bacteria-lifestyle and molecular interactions. In: van Elsas JD, Jansson JK, Trevors JT (Eds), Modern Soil Microbiology, $2^{\text {nd }}$ ed. (pp. 211-236). Boca Raton, FL: CRC Press, Taylor and Francis Group.

Takimoto A, Ramachandran PK, Nair A, Nair VD. 2008: Carbon stock and sequestration potential of traditional and improved agroforestry systems in the West African Sahel. Agriculture, Ecosystems and Environment. 125: p159-166.

Thiam S, Sambou B, Mbow C, Guisse A. 2014. Élaboration de modèles allométriques d"Acacia Sénégal L. Willd versez l'analyse du carbone ligneux en milieu sahélien: cas de la zone sylvopastorale au Sénégal. Afrique SCIENCE.10(3): p304-315.

Temperton V, Grayston S, Jackson G, Barton C, Millard P, Jarvis P. 2003. Effects of elevated carbon dioxide concentration on growth and nitrogen fixation in Alnus glutinosa in a longterm field experiment. Tree Physiology, 23 (1), p1051-1059.

Toensmeier E. 2016. Carbon sequestration potentials. In: Jorstad L. The Carbon Farming Solution. Vermont: Chelsea Green Publishing. p29-37.

World Agroforestry Centre. 2012. Faidherbia Albida keystone of Evergreen Agriculture in Africa. Available:

http://www.worldagroforestry.org/sites/default/files/F.a keystone of Ev_Ag.pdf. Last accessed $22^{\text {nd }}$ May 2016. 


\section{B-4/Wood energy or stoves}

\section{Rationale and objectives}

When used and managed appropriately, wood energy is a renewable source of energy obtained from timber in forests or plantations. If not properly planned and managed, the expansion of this bioenergy production will trigger both direct and indirect land-use changes, leading to destruction of forests and the loss of certain ecosystems, resources and the services that such systems provide. Unfortunately, this is already the case not only in West African, but also in other African countries. Annual deforestation rates are commonly at $1 \%$ in West Africa, which in practice means the loss of tens of thousands of hectares of land per year. Even though reforestation campaigns and sustainable forest management campaigns have been initiated, their scale is nowhere close to that of deforestation.

Furthermore, deforestation in the Sahelian countries is often the first step towards desertification. The situation is made worse by the fact that woody biomass and residues from both agriculture and forestry - in the form of fuelwood and charcoal - are the main sources of energy for most of these countries. This is more prevalent in rural areas and at the household level (for both cooking and heating), where wood fuels may represent up to $96 \%$ of the used energy (Arevalo 2016). Thus it is understandable that population increase and agriculture are one of the main reasons for the reduction of natural resources as this results in a higher demand for both food and fuelwood. It follows that agricultural development and sustainable forest management are the number one practical methods with which to battle deforestation and land degradation.

Another point of view to using wood as energy is provided when climate change is considered. The implications of using wood as fuel on the global environment can be evaluated by estimating the associated greenhouse gas emissions. These calculated carbon dioxide emissions can then be compared to those produced by using alternative fuels such as coal, petroleum and natural gas (RWEDP 1997). A given advantage of using wood fuel as energy is that it is renewable. This means that more trees can be replanted to sequester carbon dioxide emissions that are produced from transporting and burning of the wood. But this is the case only if forest growth and increment of forest area is higher than cuttings (industrial cutting + energy wood cuttings).

Additionally, the implementation of fuel-efficient cooking stoves can greatly reduce the amount of energy lost while cooking. This decreases the amount of firewood used, exposure of children to accidents in the home, risks of contracting respiratory diseases and the number of trips made by local communities to fetch this firewood which can be risky. Consequentially, this result in decreased amount of deforestation and harvesting firewood which in turn helps mitigate climate change. In BIODEV WP1.4 the calculations indicated a $30-40 \%$ savings in the amount of solid fuelwood in improved stoves and $10-15 \%$ savings using charcoal. This is a remarkable amount of wood (Torssonen et al. 2015).

Utilizing wood as a fuel and ultimately pairing it up with the use of fuel-efficient cooking stoves can largely reduce the overall amount of carbon dioxide produced. Although burning wood still results in emission of $\mathrm{CO}_{2}$ gas, the carbon footprint is greatly reduced as opposed to non-renewable sources of energy. This is supported by the empirical results obtained by 
Shafiei and Salim (2014), where they postulated that non-renewable energy consumption increased $\mathrm{CO}_{2}$ emissions, whereas renewable energy consumption decreased $\mathrm{CO}_{2}$ emissions in OECD countries. West Africa is not a member of the Organization for Economic Cooperation and Development (OECD), but is highly dependent on wood for fuels.

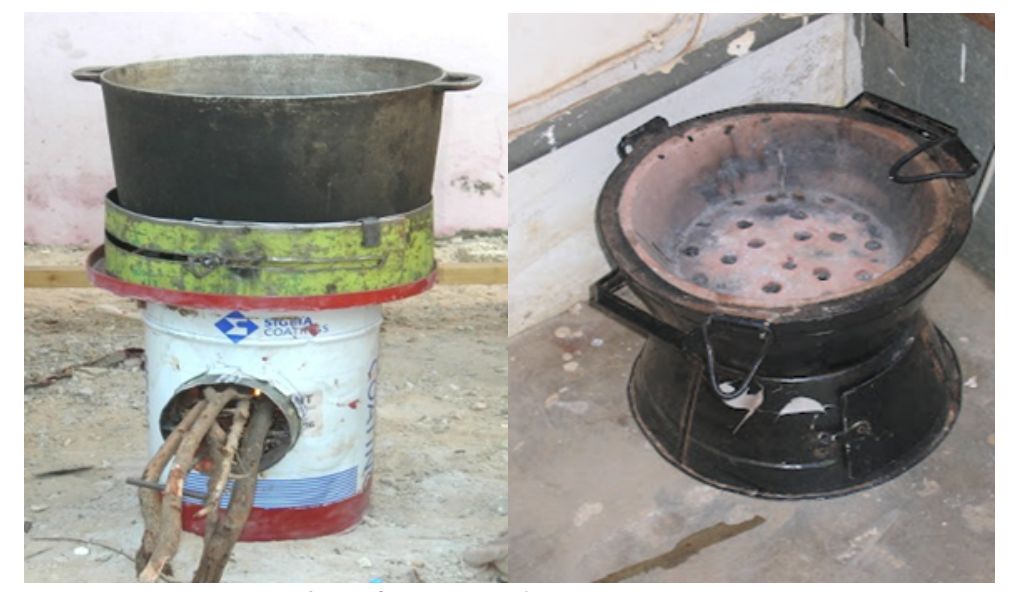

Figure 3.4.1: Examples of improved energy stoves

Implementing the use of cooking stoves could greatly reduce the amount of carbon dioxide emissions produced from burning wood. This can instigate a carbon negative country that enhances carbon sequestration rather than emitting carbon dioxide. Wood can also be converted into charcoal. This is probably the step in the charcoal value chain with the highest potential for reducing greenhouse gas emissions. However, charcoal is still being produced using traditional methods and further development on charcoal production from wood can play an important role in the mitigation of climate change (World Bank Group 2011). In the charcoal experiments of WP1.4 it was found out that the process can be improved by $10-15 \%$ (comparing how much wood is needed to the same amount of charcoal and energy) if the methods are converted more efficient by very simple means (Vilppo 2015).

Solid biofuels such as wood have a number of advantages and disadvantages, some of which are presented in table 3.4.1 (Siegel 2012).

Table 3.4.1: Advantages and disadvantages of solid biofuels

\begin{tabular}{|l|l|}
\hline Advantages & Disadvantages \\
\hline Generally low cost inputs & $\begin{array}{l}\text { Land utilization can be considerable. Can lead to } \\
\text { deforestation }\end{array}$ \\
\hline Abundant supply & $\begin{array}{l}\text { May compete directly with food production (e.g. } \\
\text { corn, soy) }\end{array}$ \\
\hline Widely available and naturally distributed & $\begin{array}{l}\text { Not totally clean when burned (NO } \\
\mathrm{CO}, \mathrm{CO}_{2} \text { ) }\end{array}$ \\
\hline $\begin{array}{l}\text { Can beot, ash, } \\
\text { independence }\end{array}$ & Heavy feed stocks require energy to transport \\
\hline Low carbon, cleaner than fossil fuels & Not easily scalable \\
\hline $\begin{array}{l}\text { Can convert waste into energy, helping to deal } \\
\text { with waste }\end{array}$ & $\begin{array}{l}\text { Energy intensive to produce. In some cases, with } \\
\text { little or no net gain }\end{array}$ \\
\hline Renewable energy & At the moment not sustainable in Africa \\
\hline Source: Siegel 2012 &
\end{tabular}


The disadvantages listed above can be overcome through sustainable management techniques such as coppicing, pruning and using cooking stoves to reduce the amount of firewood needed. This will decrease deforestation, cut down emissions from burning wood and lessen the load of firewood for transportation. Therefore, in this context it is clear that using wood fuel that is managed sustainably can help sequester carbon dioxide which in turn mitigates climate change.

\section{Data and information requirements}

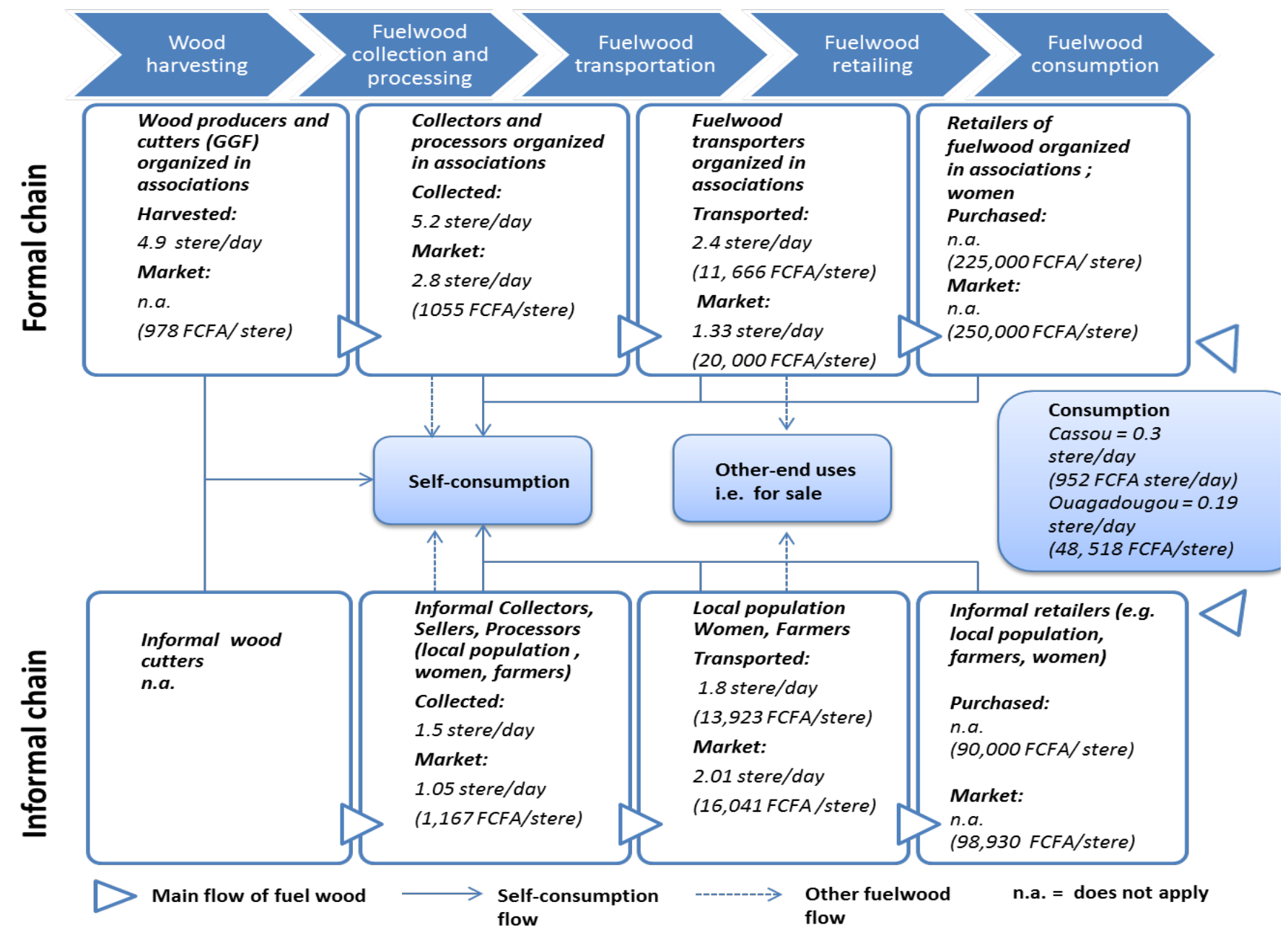

Figure 3.4.2: Fuelwood value chain with main stakeholders, quantities (steres/day) and prices (FCFA/stere) in each process and considering formality of the activities

The demand module requires socioeconomic and demographic data, as well as data on wood fuel consumption from local surveys. For the supply module, detailed land use/land cover inventories and a national forestry inventory should be in place. In addition, data would be required on: biomass stocking from non-forest land-use classes (typically from local studies); available infrastructure for wood/biomass transport and processing; and agricultural area especially data on wood fuel supply, which has been a major issue in wood fuel analysis for many years. In WP1.4 of the BIODEV project, a value chain analysis (VCA) of energy wood was carried out (Puentes et al. 2016) based on interviews of stakeholders and the field data measured. It showed that one of the main problems in VCA, and also in forest management, is the informal chain and especially in the determination of the amount of 
informal cuttings for domestic use and for informal markets. There is basically no control in that and if the forest management decisions are based on the formal information, it leads to forest loss. This study also proved how important it is to combine information from many sources like forest inventory and VCA to be able to get a clear understanding of the complex situation.

Often, the only piece of data available for the supply module is the national forest inventory. Detailed information on non-forest and other land use classes is not available in most cases. With regard to consumption, data is often available for only part of the country and sometimes is collected using incompatible methodologies. This data gap can be overcome by:

1) Using a proxy variable to "spatialize" discontinuous values.

2) Extrapolating information available at the project level to an entire study region.

3) Filling specific or critical data gaps with new data coming from field studies.

The main challenge is to find direct or proxy variables available at the national level that can be used to estimate production/consumption parameters and their spatial distribution. A project promoting the use of wood fuel and cooking stoves would portray a baseline scenario and project scenario in relation to reducing carbon dioxide emissions as shown in figure 3.4.3.

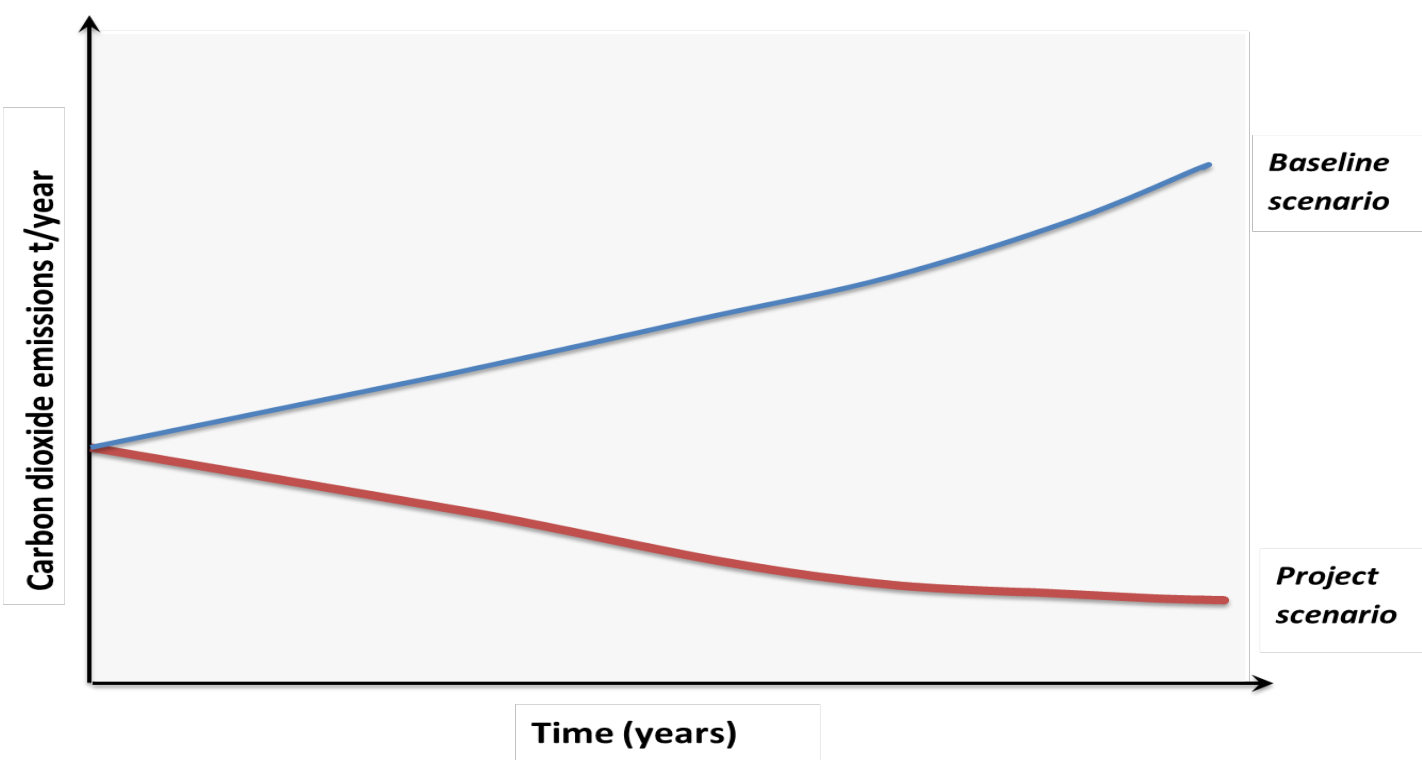

Figure 3.4.3: The baseline scenario and project scenario in a carbon dioxide emission reduction project

In the business as usual scenario (baseline) emission trend follows an increasing steep curve. The project scenario shows a reverse trend magnifying the abatement effort of the project. Figure 3.4.3 illustrates the expected trends of carbon dioxide emissions when instigating the use of wood fuels and cooking stoves in a project scenario and before the plan is commenced in a baseline scenario. The carbon dioxide emissions reduce when fossil fuels are replaced with renewable energy thereby depicting a decreasing trend line in a project scenario and an increasing trend line in the case of a baseline scenario. 
A similar trend could be observed in the amount of forest resources: their amount increases as the amount of sustainably-managed lands increases. Future trends can even become such that the amount of forest land stays stable, but the amount of forest resources keeps on growing due to better forest management and more efficient stoves and fuelwood production methods.

\section{Carbon abatement potential}

The carbon abatement potential refers to the relative amounts of carbon dioxide emissions that are reduced and sequestrated through the use of wood as fuel and efficient cooking stoves. Global energy consumption is increasing with respect to rising human populations and industrialization. Therefore, it is fundamental to make energy changes as soon as possible to avoid accelerating the process of climate change and risking the exploitation of fossil fuels which take years and years to be produced. The Ghanaian National Climate Change Policy Framework constructed a Marginal Abatement Cost Curve (MAC curve) for household energy demand in the country for the year 2020 disclosing five strategies to lower carbon dioxide emissions. These are shown in figure 3.4.4:

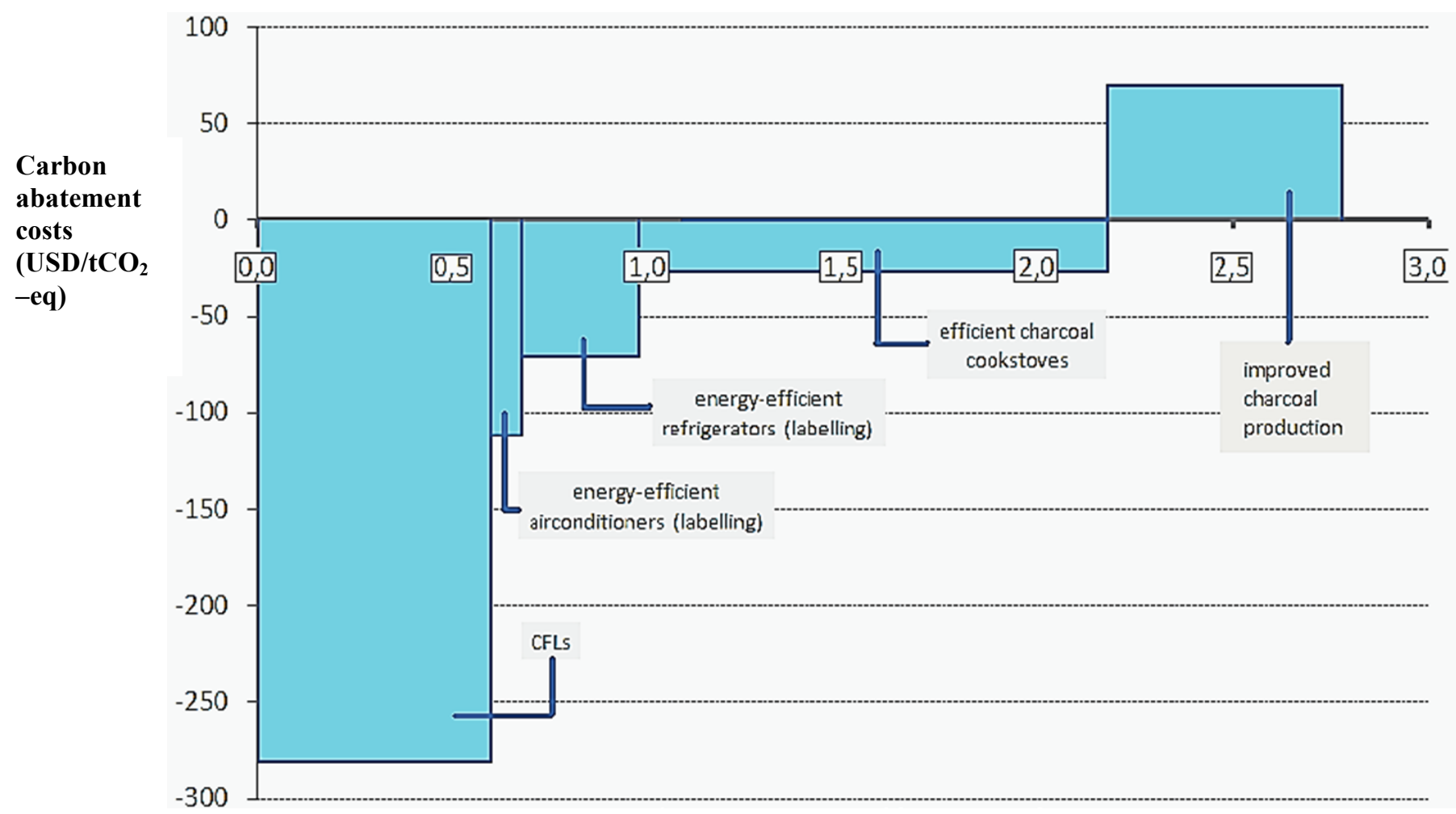

Abatement potential (Mt $\left.\mathrm{CO}_{2}-\mathrm{eq}\right)$

Figure 3.4.4: A Marginal Abatement Cost Curve for household energy in Ghana for the year 2020 (Source: Tilburg et al. 2011)

Figure 3.4.4 indicates that at least four of the stated $\mathrm{CO}_{2}$ lowering strategies have negative costs and therefore provide net economic benefits while reducing the emissions of greenhouse gases. The replacement of light bulbs with Compact Fluorescent Bulbs (CFLs) is the most cost effective, but the implementation of efficient cooking stoves and improved 
charcoal productions depict the largest potential for reducing carbon dioxide emissions (Tilburg et al. 2011). The cost of improved charcoal production using wood according to Tilburg et al. (2011) is only indicative due to lack of data available in the under-developed sector. To secure the positive effect of using these more efficient methods and techniques it is important to secure the forest growth and sustainability as well. The implementation of more efficient techniques alone do not improve the situation if no attention is paid to increase the forest cover.

Thus, this data and information obtained from Ghana can be expanded throughout the remaining West African countries. The data puts emphasis on carbon dioxide emissions produced in urban households and rural areas.

\section{Costs and investments}

Promoting the use of wood for fuels and charcoal production and simultaneously utilizing efficient cooking stoves in households can be relatively costly. Although the benefits accrued by the implementation of renewable wood energy and efficient cooking stoves surpass the costs, it is still important to analyse the proposal to ensure a successful, well thought out, budgeted project that can be expanded across Sub-Saharan Africa. A number of costs and investments to consider are:

i) Educating farmers and local communities on sustainable harvesting techniques This is an investment present in almost every carbon project. A large number of locals have not received formal education for almost all their lives, so it is necessary to tutor them regularly on advanced methods of sustainable harvesting techniques and tools. Additionally, this reduces the rates of deforestation, thus hindering climate change while concurrently allowing the surrounding communities to utilize sources from the forested land or plantations through techniques such as coppicing and pruning.

ii) Educating farmers and local communities to secure the regeneration through seedling production and planting - Seedling production is a key element in most of the areas around the villages and if no planting is done it is basically impossible to secure forests in the future. In addition, political decisions and change in forest policy is required to ensure that farmers have control over the land.

iii) Costs of estimating carbon dioxide emissions from wood fuels and cooking stoves - These refer to conducting land cover/forest inventories.

iv) Seedlings and fertilizers - This is conditional as the species of trees required for timber may vary, therefore seeds and fertilizer may be required. Additionally, nitrogen-fixing trees can be planted along with the trees to enhance the quality and yield.

v) Approximating wood fuel usage using local surveys - Distributing the surveys could be time consuming and costly but is fundamental in assessing $\mathrm{CO}_{2}$ emissions produced.

vi) Training the staff - In order to attain accurate figures on carbon dioxide emissions from using wood as a fuel and efficient cooking stoves, staff must be skilled and have deep knowledge on the process required. It is vital to acquire accurate results as these data are then compared to those of fossil fuels to assess which of the fuels are less harmful to the environment. 
vii) Capital for providing efficient cooking stoves to local communities - Over the years, the cooking stoves have become more and more efficient reducing the amount of emissions produced and the amount of wood fuel required. A modern efficient cooking stove comes at an average price ranging from $\$ 100-\$ 400$ depending on the material, the size and the make of the stoves.

viii) The costs of transporting the wood - This depends on the purpose of the wood. Locals can carry a limited amount of wood to and from the site. However, companies using wood for alternative purposes would use heavy duty trucks which are carbon emitting and costly. Additionally, local communities make use of their livestock or invest in livestock to assist in the transportation of wood.

These are only a number of the costs and investments procured in the general project. There may be additional costs related to the implementation of wood energy and efficient cooking stoves which may however, be minor. Supplementary funds would be beneficial in this case.

\section{Environmental and socioeconomic benefits}

Although the use of wood energy contributes to environmental degradation, when evaluated against fossil fuels the latter is positive, especially when sustainability and forest regeneration are included. Even though the harvesting of wood for cooking and heating results in emission of carbon dioxide, the fact that it is renewable, is readily available and can sequester carbon dioxide through replanting of trees makes it a more favourable source of energy. In contrast, fossil fuels emit larger amounts of carbon dioxide, require investments and processing before they can be used, and may one day be exhausted. World Vision (2011) established that installation and correct use of improved stoves reduced greenhouse gas emissions by approximately $74 \%$. Furthermore, there was reduction in soil erosion, improvement in the soil fertility and water holding capacity of the soil.

Using wood for fuel enhances the conservation of forests only through sustainable harvesting practices and secured regeneration (plating) and also by the use of efficient cooking stoves, as the amount of wood fuel required is substantially reduced. The social benefits in this context are: safer environment for children as there is reduction in the amount of smoke produced and the risk of accidents, and women can spend less time collecting fuel and can instead take care of their children or start working for additional income (World Vision 2011). In addition, if the forest cover is increased, the livelihoods of communities could improve - by adequate food, shelter and income generating activities.

In regards to economic benefits, the wood energy sector creates considerable amounts of employment and income, as some of the wood fetched can also be sold to other companies at higher prices. Additionally, the wood energy can be used to produce varying goods and services such as heating, cooking and lighting.

\section{Institutional framework and management schemes}

The development of wood energy and efficient cooking stoves can be achieved through the implementation of effective management schemes and institutional frameworks that work towards sustainable development for future generations. In addition, education for decision makers and politicians to ensure the political will is important. 
Further research and project implementation by institutions including ICRAF, CIFOR, USAID, UNEP, FAO, World Vision and the Africa Renewable Energy Access Programme (AREAP), among others, is required. These institutions have made a difference to African communities by promoting sustainable harvesting techniques, reducing dependence on fossil fuels and supplying homes with efficient cooking stoves. This is made possible with funding received from donors such as the World Bank, Africa Development Bank and Good Samaritans.

\section{Monitoring requirements}

As stated above just increasing the efficiency of cooking and charcoal processes do not ensure sustainable and renewable wood energy. In fact, at the moment, wood energy is not renewable in African countries as can be seen from the huge deforestation rates. Sierra Leone and Burkina Faso are good examples of this. According to the Ministry of Energy and Water Resources, Sierra Leone, vast deforestation occurs in the country due to the massive dependence of its over 7 million people on woodfuels (MEWR 2009). In Burkina Faso from the 5.4 million hectares of forests (FAOSTAT 2015) -including 3.9 million hectares of stateowned forest reserves - the annual forest loss during 1992-2002 according to the government was 107,626 hectares and annual forest degradation equivalent to 0.5 million hectares (MEDD 2012a). 90\% of the population utilizes wood energy in the form of firewood and charcoal (REEEP 2012). These figures show clearly that the forest management is not sustainable and the wood energy is not renewable at the moment.

To improve the situation and to make wood energy a truly renewable source, forest loss must be stopped through active and massive regeneration actions, intensification of agriculture, as well as promotion of agroforestry. This will require political will, education at all levels and active input to seedlings. People at all levels will need to be motivated to carry out regeneration, not only through planting, but also through sustainable forest management.

To monitor the success in these activities a proper forest inventory is needed. In BIODEV project WP1.4, a suitable method for monitoring and measuring the above-ground biomass as well as the calculation procedure for available energy wood in sample plots were presented (Heiskanen and Packalen 2013, Valbuena et al. 2016). This kind inventory system with remote sensing data should be applied to be able to monitor the changes in forest land area and amount of available woody biomass. Only then can proper management plans be made for sustainability.

In addition, there is need to examine the different value chains and the business around forest goods to improve efficiency (like in marketing and transporting goods) and to make sure that there are no overlaps in the use of natural resources. Equally important is the need to learn about the different formal and informal processes and chains since they both affect the amount of available biomass (Puentes et al. 2016). This would promote development of new business models for women and thus improve their standards of living.

\section{Challenges and barriers}

Some of the difficulties experienced by institutions in successfully implementing the switch to wood energy and efficient cooking stoves are: 
i) Alternative purposes of an open fire - Indoor fires for cooking food often serve other purposes such as heating indoor areas, preserving food through smoking, keeping thatched roofs dry and rot-free, repelling mosquitoes and lighting. Improved stoves do not address all of these needs, and hence need to be part of the broader sustainable development efforts (World Vision 2011).

ii) Compatibility with local fuels and foods - Cooking stoves have to come in a variety of shapes and sizes to enable certain pots and pans to accurately fit and consume energy from the stove entirely so that none is wasted (World Vision 2011).

iii) Community acceptance - Different communities and individuals may have different criteria by which they evaluate a stove's merits - and often those criteria differ from the ones dictating a stove's design. A stove may be designed to maximize energy efficiency and reduce smoke, for example, but stove users may also judge the model based on factors like safety, convenience, price and perceived durability (World Vision 2011).

iv) Insufficient funding - Appropriate amounts of capital are required to enable the commencement of the project.

v) Deforestation - If wood is not harvested in sustainably, the outcome would be a reduction in overall tree cover and excess emissions of carbon dioxide into the atmosphere, further triggering climate change.

vi) Using land to grow trees for wood fuel leading to direct competition with food crops - This matter would require precise sustainable land management strategies, for example, instigating agroforestry systems.

vii) Produces $\mathrm{CO}_{2}$ emissions through burning of wood and transportation - The public needs to be aware that these emissions produced are less than those emitted by fossil fuels. Additionally, harvesting techniques such as coppicing and pruning and using efficient cooking stoves can ultimately reduce carbon dioxide emitted through burning and transportation. Planting more trees can sequester excess carbon dioxide produced through burning and transportation of wood.

Further research on sustainable development and needs of local communities could enhance the effectiveness of the project in reducing carbon dioxide emissions.

\section{Capacity development}

Capacity development on wood energy and efficient cooking stoves specifically focuses on improving the socioeconomic viability, ecological sustainability, resource efficiency and emissions of greenhouse gases (FAO 2015). Projects implementing the use of wood energy and efficient cooking stoves can be more successful and resourceful. This can be achieved through bridging the gaps in education, collecting and improving data acquired and raising awareness of the importance of wood energy. Additionally, researching on modern and improved sustainable and resource-efficient production and consumption of wood, and increasing the frequency of training workshops so that locals can learn from one another are also key.

Capacity building allows the advancement of the proposed projects so as to attain the expected results and improve environmental and socioeconomic factors. Institutions 
working together on a large scale can bridge these gaps in research and improve the aspects of future sustainable development.

Equally important is to offer and carry out training at all levels (from decision makers and politicians, to farmers) about sustainable forest management, while offering knowledge on ecology and economy related to forests. It must be clear for everybody that there are no markets, no businesses and no money if the forests are lost. The connection between the different items must be clear to everyone.

\section{Sustainable energy wood management}

Based on the work and research of WP1.4 on energy wood, it is clear that only renewable and sustainable energy wood can be obtained if the forest management is based on sustainability and the forested land area cover is increased. Based on the results of WP1.4 issues touching on the sustainability of the wood based energy include the following (Torssonen et al. 2015):

i) There is need to develop forest policy and forest law.

ii) A systematic national forest inventory must be launched to track changes in wood biomass.

iii) Training at all levels is a key factor. There is need to build the capacity of communities, farmers, forest managers, wood sellers, researchers, teachers, businesspeople, politicians and decision makers.

iv) Need to build up a strategic plan for sustainable woodfuel management. In this paper, this work is started and the recommendations of the WP1.4 working group are presented.

v) Improved and up-to-date teaching on climate issues, biodiversity, forests and forestry at all levels of education, from primary schools to universities. In this BIODEV project, the working group of WP1.4 took the first step by training staff from Njala and Ougadougou Universities on sustainable wood energy management and by publishing a text book for universities.

vi) Need to improve charcoal production to reduce the energy loss in the process.

vii) Need to combine agroforestry and fuelwood production to increase access to fuelwood plantations and income for farmers (producing and selling fuelwood in the area).

Figure 3.4.5 highlights the suggested chain to guarantee the sustainability in forest management (Torssonen et al. 2015). 


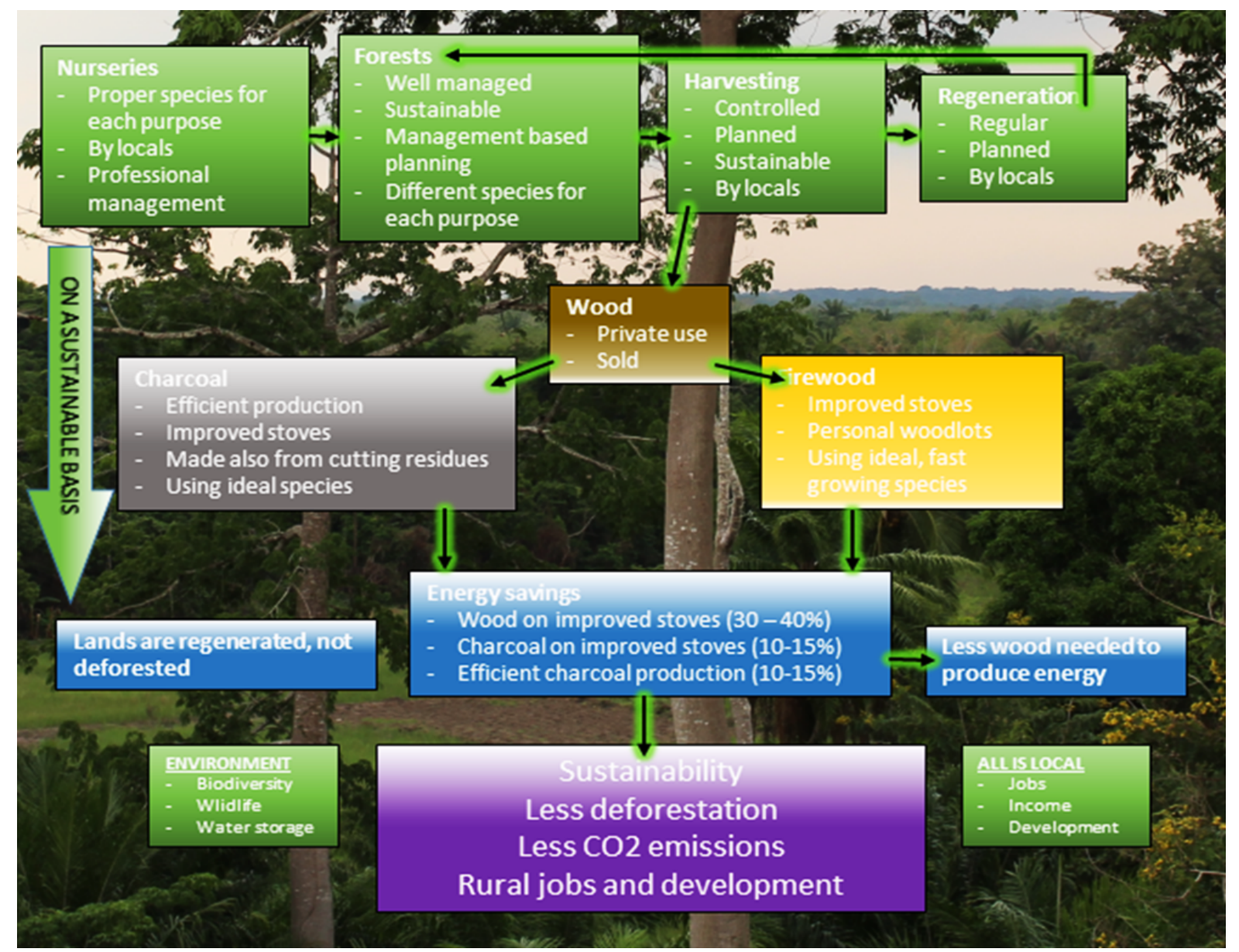

Figure 3.4.5: A flowchart depicting the ideal way of managing the forests and producing income, products and development on a sustainable basis

\section{References}

FAOSTAT 2015. Online Database. FAO, Rome. Retrieved from http://faostat3.fao.org/home/E

Food and Agriculture Organization. 2015. Wood Energy. Available:

http://www.fao.org/forestry/energy/90828/en/. Last accessed 29 ${ }^{\text {th }}$ May 2016.

Heiskanen J, Packalen P. 2013. Field measurement protocol to estimate aboveground biomass and fuelwood stocks. $12 \mathrm{p}$

MEDD 2012a. Readiness preparation plan for REDD. Ministry of Environment and Sustainable Development, Burkina Faso.

MEWR 2009. National Energy Policy and Strategic Plan. Ministry of Energy and Water Resources, Sierra Leone.

Puentes Rodriguez Y, Torssonen P, Ramcilovik-Suominen S, Pitkänen S. 2016. Fuelwood value chain analysis in Cassou and Ouagadougou, Burkina Faso: From the production to the consumption. Manuscript. $21 \mathrm{p}$.

REEEP 2012. Web-based Resources, Policy Database, Renewable Energy and Energy Efficiency Partnership. Retrieved on $11^{\text {th }}$ January 2016 from http://www.reegle.info/ Regional Wood Energy Development Programme. 1997. Regional Study on Wood Energy Today and Tomorrow in Asia. Available:

http://ftp.fao.org/docrep/fao/W7744E/W7744E00.pdf. Last accessed 26 ${ }^{\text {th }}$ May 2016. 
Shafiei S, Salim R. 2014. Non-renewable and renewable energy consumption and $\mathrm{CO}_{2}$ emissions in OECD countries: A comparative analysis. Energy Policy. 66 (1), p 547-556. Siegel R. 2012. Biomass Energy: Pros and Cons. Available:

http://www.triplepundit.com/special/energy-options-pros-and-cons/biomass-energy-proscons/. Last accessed $27^{\text {th }}$ May 2016.

Tilburg X, Würtenberger L, Rivera R, Atta-Owusu F. 2011. Policy brief: Low carbon options for energy demand. Available: https://www.ecn.nl/docs/library/report/2011/o11022.pdf. Last accessed $28^{\text {th }}$ May 2016.

Torssonen P, Pitkänen S, Melin M, Kilpeläinen A, Packalen P, Puentes Y, Ramcilociv-

Suominen S, Valbuena R. 2016. Towards sustainable woodfuel management. Strategic plan. Available on the website of BIODEV.

Valbuena R, Heiskanen J, Aynekulu E, Pitkänen S, Packalen P. 2016. Sensitivity of aboveground biomass estimates to height-diameter modelling in mixed-species West African woodlands. Manuscript. 45p.

Vilppo T. 2015. Simple methods to improve biochar yield. 3p. Available on the website of BIODEV.

World Bank Group. 2011. Wood-Based Biomass Energy Development for Sub-Saharan Africa: Issues and approaches. Washington: Africa Renewable Energy Access Programme. p1-64.

World Vision. 2011. Fuel-efficient cooking stoves: a triple win for child health, development and the environment. Available: https://www.worldvision.com.au/docs/defaultsource/publications/climate-change/wv fuel-efficientcookingstovesreport.pdf?sfvrsn=6. Last accessed $28^{\text {th }}$ May 2016. 


\section{B-5/Land restoration for carbon sequestration}

\section{Rationale and objectives}

Land Use Land Cover (LULC) change contributes a considerable amount of global anthropogenic greenhouse gas emissions, accounting for an estimated $12.5 \%$ of carbon emissions from 1990 to 2010 (Houghton et al. 2012). Approximately 52\% of the world's forests are concentrated in the tropics, which have the highest rates of deforestation and land conversion globally (Brown et al. 1996). West Africa is dominated by tropical forests which stretch from Sierra Leone all the way to vast regions of Ghana. Only about $15 \%$ of the original forest hotspot vegetation cover of Guinea remains today due to deforestation for agricultural purposes and human settlements, compared to $18 \%$ of hotspot vegetation cover at the beginning of the millennium (Gockowski and Sonwa 2010, CEPF 2016). This land use change resulted in substantial amounts of carbon dioxide emissions due to the reduction in standing biomass for growing cash crops.

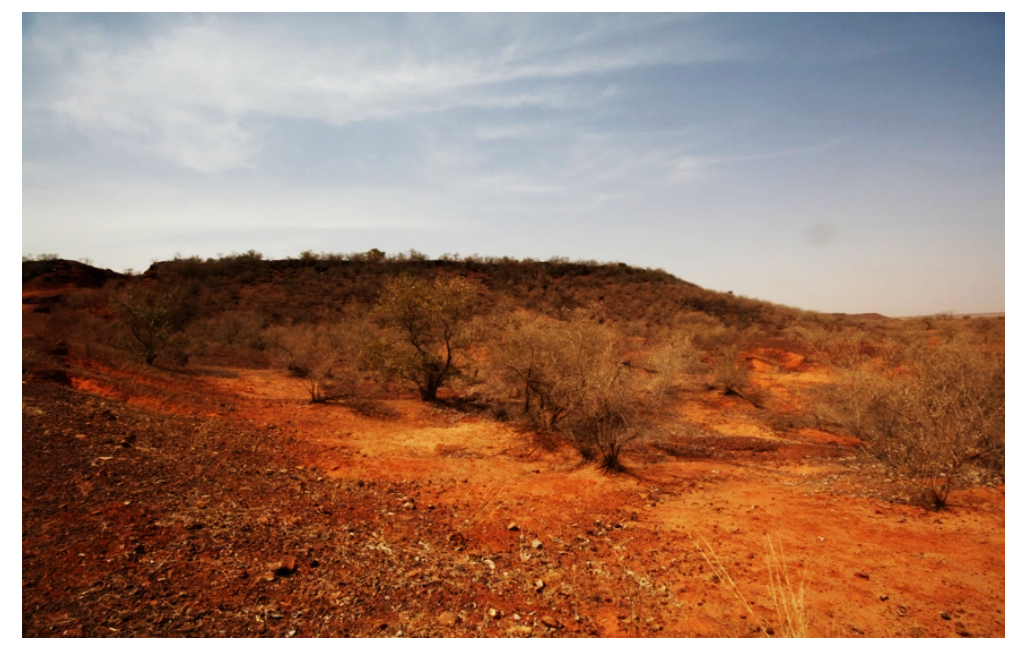

Figure 3.5.1: An image of degraded land in Niger (Source: Hannah 2013)

Although clearing land to grow crops for social and economic purposes may seem normal in developing countries, it is greatly affecting the environment, the soils and the quality of the produce. Reduction in soil fertility and quality of produce could be attributed to the subsequent increase in soil erosion, lack of nutrients due to leaching and reduced litter decomposition which enhance and regulate the nitrogen and carbon cycles. Additionally, deforestation rates have led to emissions of carbon dioxide, thus accelerating climate change.

The fate of land use is controlled by the human population and to a large extent, individuals, businesses, non-profit organizations and governments that can make land decisions to adapt/reduce the effects of climate change (Brown et al. 2014). A few adaptation options postulated by Brown et al. (2014) aimed at reducing the process of climate change include:

i) Expanding forests to accelerate removal of carbon from the atmosphere.

ii) Modifying the way cities are built and organized to reduce energy consumption and reduce land use change.

iii) Altering agricultural management practices to increase carbon storage in aboveground biomass and soil. 
These solutions can be applied across the world to minimize the growing emissions of carbon dioxide produced through land use change. Land restoration entails techniques such as reforestation, afforestation, agroforestry, agropastoral, agrisilviculture and agrosilvopastoral methods which substantially increase carbon sequestration and in turn reduce the process and effects of climate change.

\section{Data and information requirements for land restoration}

Quantifying emissions from LULC change remains one of the most uncertain components in carbon budgeting, particularly in landscapes dominated by smallholder agriculture (Brown et al. 2007, Houghton et al. 2012, Smith et al. 2012, Kearney and Smulker 2015). According to Kearney and Smulker (2015), a number of steps are required to estimate greenhouse gas emissions/removals from LULC. These include:

i) Determine variations in Land Use Land Cover Changes - This must be done by comparing data from two or more points in time.

ii) Develop a baseline - The observed changes in carbon stocks must be compared to a scenario without the implementation of land restoration. This is carried out by either developing a baseline scenario or through direct observation of a region.

iii) Calculate carbon stock changes - Greenhouse gas emissions can be used or alternatively, the carbon stocks can be measured using the methodology stated in A2 for each land class.

iv) Assess accuracy and calculate uncertainty - Accuracy of each step must be assessed in order to determine the uncertainty associated with final emissions/removals estimates associated with LULC changes.

Determining the changes in LULC can be done through remote sensing techniques which yield accurate data. Comparisons can be made with the satellite images obtained from two or more points in time to give an estimation of the fate of the carbon stocks in the ecosystem over time. Additionally, developing a baseline and project scenario for land restoration are dependent on the type of land-use category which could be: forest land, cropland, grassland, wetlands, or settlements. Changing crop land to forest land and incorporating agroforestry would increase carbon sequestration largely due to increase in standing biomass. Land restoration projects should aim to increase the carbon sequestration to the greatest potential by even planting nitrogen-fixing trees and adding fertilizer so as to increase production and yield of biomass, as well as sequester large amounts of carbon dioxide. Therefore, in a land restoration project the baseline-project scenario graph would be similar to that illustrated figure 3.1.2.

\section{Carbon abatement potential}

The carbon abatement potential varies across each land use category. Evidently, tropical forests are the largest carbon sinks due to their vast canopies, diverse species and ecological systems. Land restoration can however, also sequestrate carbon dioxide in possibly similar amounts with the integration of fertilizers, nitrogen-fixing species and agroforestry.

Table 3.5.1 presents examples of carbon stocks in various land-use categories to illustrate the highest carbon sequestrating ecosystems that could be largely beneficial to the environment. 
Table 3.5.1: Carbon sequestration potentials of varying biomes

\begin{tabular}{|l|l|}
\hline Biomes/ecosystems & Carbon sequestration (Pg C per year) \\
\hline Agricultural lands & $0.85-0.90$ \\
\hline Biomass croplands & $0.50-0.80$ \\
\hline Grasslands & 0.50 \\
\hline Forests & $1-3$ \\
\hline Deserts and degraded lands & $0.80-1.30$ \\
\hline Terrestrial sediments & $0.70-1.70$ \\
\hline \\
DOE 1999
\end{tabular}

Forests contain the largest amount of standing biomass and therefore sequester great amounts of carbon dioxide through the process of photosynthesis. Increasing the amount of carbon sequestered in the biomes listed above could be done by planting more trees and using sustainable management and harvesting practices.

Therefore, converting even agricultural land to a forested landscape delivers large environmental benefits and simultaneously carrying out cropping and intercropping, the socioeconomic benefits can also be increased.

\section{Costs and investments}

Launching a land restoration project involves a huge investment. A number of the costs and investments procured include:

i) Educating the public, local communities and farmers on the importance of land restoration and sustainable farming - This involves advertisements, seminars, forums and possibly courses taught by well trained and skilled individuals.

ii) Incentives for workers - Funding must be adequate to pay for labour and sufficient amounts of capital.

iii) Incentives for farmers to enable them to continue their agricultural practices outside the project site - To restore land that has been excessively degraded through agriculture, farmers may be forced to temporarily carry out their practices elsewhere. This requires a certain sum of capital to allow them to start all over again and ensure they begin using sustainable management techniques.

iv) Capital for materials and instruments for carbon inventory and estimating greenhouse gas emissions - Estimating carbon stocks and emissions require greenhouse gas chambers, measuring tapes, clinometers, compasses, pegs, remote sensing software and GPS (see A-2).

v) Seeds and fertilizers - Restoring land requires investments in seeds and fertilizers for maximum yield production and carbon sequestration.

vi) Management techniques - Materials required for processes such as coppicing, pruning, live fencing, and reduced tillage, among others.

vii) Monitoring methods - Land restoration must be monitored frequently, at least once a year.

viii) Restoring soil fertility and conducting laboratory tests on soils - If the land to be recovered was a previous coal mine, substantial amounts of fertilizer and soil analysis tests are required to ensure there is no arsenic poisoning if the land is being restored for agricultural use.

The cost benefit analysis in this case must carefully be examined to ensure that the benefits attained from the conversion of land offset the expenses. 


\section{Environmental and socioeconomic benefits of land restoration}

Depending on the land use category and carbon sequestration potential, the environmental and socioeconomic benefits are vast. However, the most efficient method of increasing carbon sequestration while concurrently encouraging socioeconomic development is by planting species of trees that are most used and beneficial for local communities, and incorporating nitrogen-fixing trees for soil fertility. Further environmental benefits other than mitigating climate change include improvement in soil fertility, reduction in soil erosion, improvement in crop yields due to increased carbon sequestration by nitrogenfixing trees and fertilizer trees which act as wind breaks and prevent flooding. In the social and economic aspects of land restoration, benefits include:

- Land restoration - Local farmers, communities and institutions are able to work together on a social level to attain a certain goal.

- Addition of fertilizers and nitrogen-fixing species improves quality and yield of any cash crops being grown. This increases the value of the produce which can be sold at higher prices, thus increasing households' incomes.

- Agroforestry land restoration can improve the nutritional diets of the local communities, thus enhancing their health.

- Growing a variety of species brings forth a variety of economic value such as timber, herbal medicines, fruit pulp and fibres.

\section{Institutional frameworks and management schemes}

Experience suggests that restoration usually only works in the long term if it has support from a significant proportion of local stakeholders (Vallauri et al. 1986). In West Africa, collaborative interest in land restoration by institutions such as ICRAF, UNEP, USAID, could be helpful as these organizations have skilled professionals who can develop proposals and secure funds from donors such as the World Bank, Africa Development Bank and the private sector.

Additionally, land restoration requires a variety of expertise like ecology, silviculture, economics, public policy, and the social sciences, which need to be combined in an efficient way. Institutional frameworks and management schemes can appropriately adhere to these requirements and provide sufficient skilled and trained staff.

\section{Monitoring methods}

Monitoring is the process of periodically collecting and using data to inform management decisions (O'Connor et al. 1986). In land restoration projects, monitoring involves the estimation of carbon stocks to assess the progress and surveys and direct observation to assess if the communities are using sustainable management techniques and if not, what actions to undertake. Figure 3.5.1 summarizes the steps of monitoring a land restoration project: 


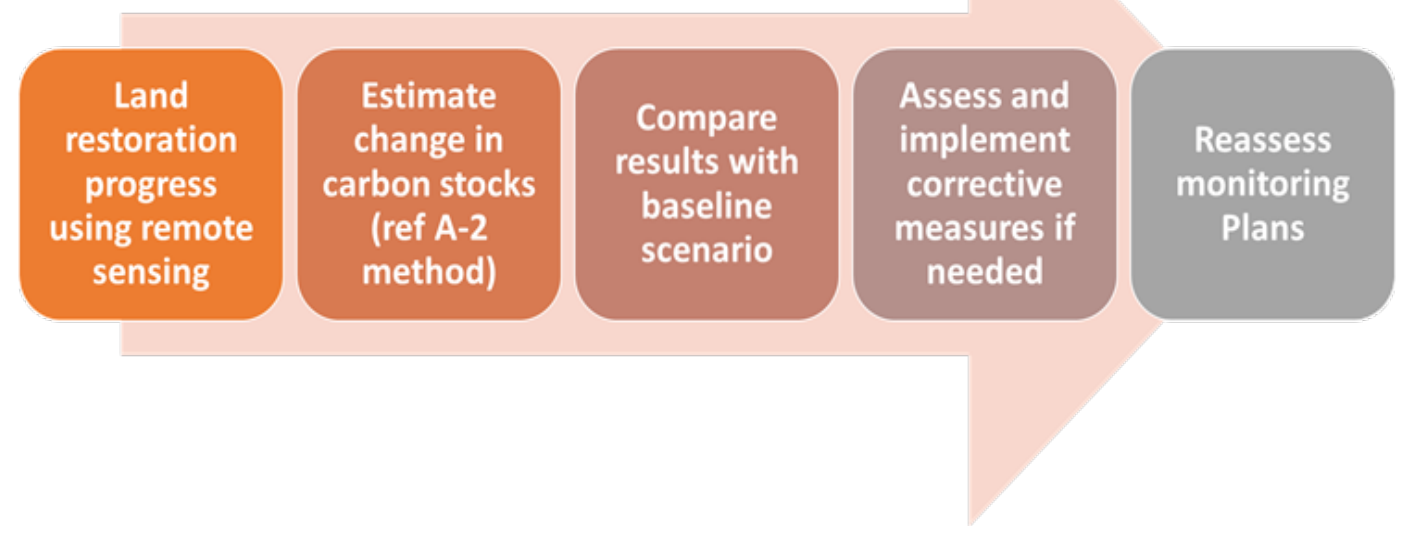

Figure 3.5.1: The steps taken to monitor progress of land restoration projects

\section{Challenges and barriers}

A successful land restoration project requires an enormous amount of institutional and community cooperation and effort. This is perhaps a social advantage as it brings together a network of people working towards a similar goal. However, it also comes with challenges such as:

i) Expensive projects that need sufficient funding - Converting land is an enormous project to take on and consists of a large number of costs and expenses.

ii) It is difficult to estimate greenhouse gas removals and emissions

iii) Land restoration project are long and extensive - Restoring a forest on highly degraded land can take approximately $10-15$ years with regular corrections and intensive-tuning (Vallauri et al. 1986).

iv) The extent of soil damage may hinder the project - If the degraded land was for instance, an ex-coal mine, the high levels of arsenic could be damaging for the growing vegetation and consequently reduce the biomass production.

v) Requirement of well skilled labour - Estimating carbon stocks and emissions from land use land cover change needs trained staff so as to ensure project accuracy.

vi) Land tenure - The project can only be executed once the go-ahead is given by the owner of the land who could have alternative plans for the area.

\section{Capacity development}

A land restoration project can be made more effective by careful planning through adapting short-term restoration goals and techniques to minimize the number of costly corrective actions. Planning ahead to secure funds for carrying out monitoring and evaluation, corrective actions, or "aftercare" in the long term is also important (Vallauri et al. 1986). Furthermore, long-term goals must also be considered to ensure that the project can be sustained over the period of time required.

Stakeholders and communities must work on developing a shared and accepted vision and goal for the landscape which would enable a more successful restoration process (Vallauri et al. 1986). Before the launch of the project, the reasons for land degradation, the root causes 
and solutions to implement must be clear to all partners. Funding and subsequent partners must be secured to avoid any challenges during project implementation.

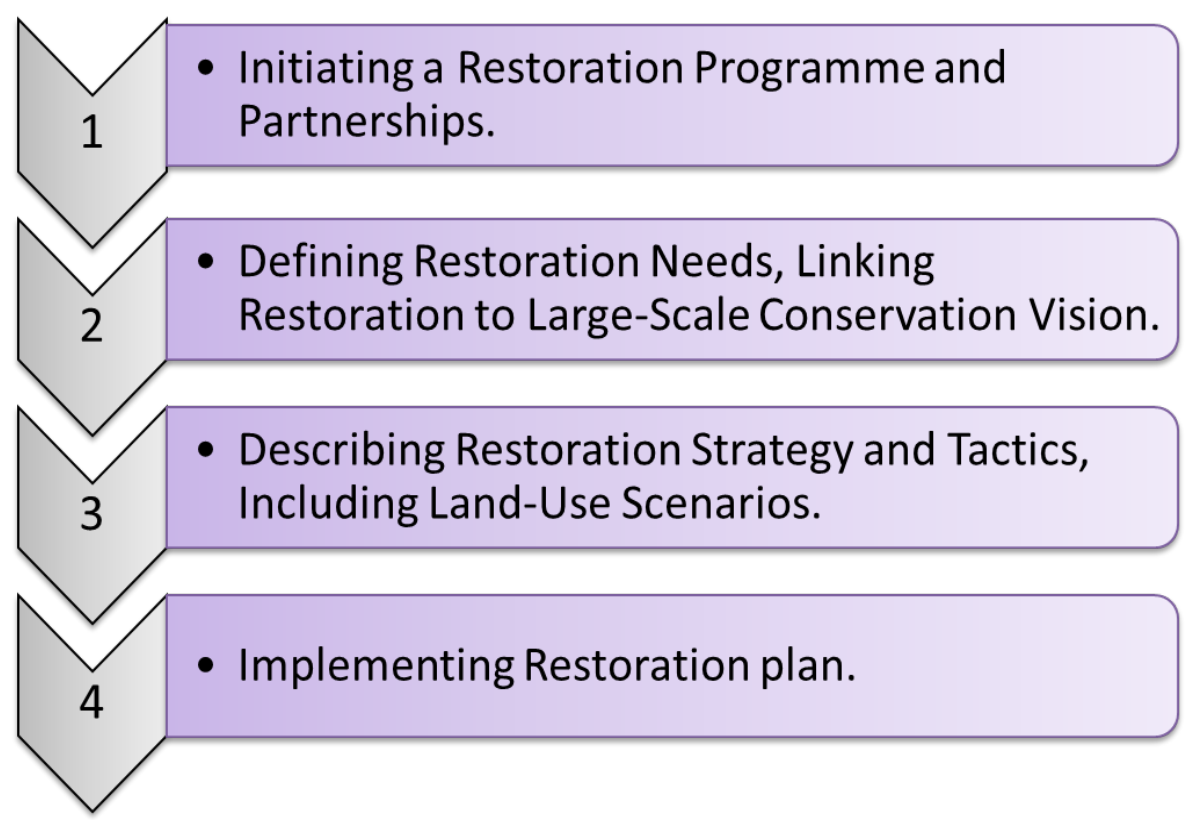

Figure 3.5.2: A series of steps taken to enhance capacity building of a land restoration project. (Source: Vallauri et al. 1986)

Following the steps in the figure above can help reduce challenges and barriers experienced in the project.

\section{References}

Brown S, Sayant J, Cannell M, Kauppi PE. 1996a. Mitigation of carbon emissions to the atmosphere by forest management. Commonwealth Forestry Review. 75: p80-91.

Brown D, Polsky C, Bolstad P, Brody S, Hulse D, Kroh R, Loveland T, Thomson A. 2014. Land use and land cover change. Climate change impacts in the United States. In: Melillo JM, Terese TC, Yohe GW (Eds) The Third National Climate Assessment, US Global Change Research Programme. p318-332. doi:10.7930/ J05Q4T1Q.

Brown S, Hall M, Andrasko K, Ruiz F, Marzoli W, Guerrero G, Masera O, Dushku A, DeJong B, Cornell J. 2007. Baselines for land-use change in the tropics: application to avoided deforestation projects. Mitig Adapt Strateg Glob Chang. 12:p1001-1026. doi:10.1007/s11027-006-9062-5.

Critical Ecosystem Partnership Fund (CEPF) 2016. Guinean Forests of West Africa. Available: http://www.cepf.net/resources/hotspots/africa/Pages/Guinean-Forests-of-WestAfrica.aspx. Last accessed $29^{\text {th }}$ May 2016.

Department of Energy (DOE) 1999. Carbon Sequestration: State of the Science. United States Department of Energy (DOE), Washington, DC.

Gockowski J, Sonwa D. 2010. Cocoa intensification scenarios and their predicted impact on $\mathrm{CO}_{2}$ emissions, biodiversity conservation, and rural livelihoods in the Guinea Rain Forest of West Africa. Environmental Management. 48, p307-321.

Hanna H. 2013. Communicating environmental challenges with photography. Available: https://thepalebluedot.me/author/hafdishanna/. Accessed $5^{\text {th }}$ Jul 2016. 
Houghton R, House I, Pongratz J, van der Werf R, DeFries R, Hansen MC, Le Quéré C, Ramankutty N. 2012. Carbon emissions from land use and land-cover change.

Biogeosciences. 9:p5125-5142. doi:10.5194/bg-9-5125-2012.

Kearney S, Smukler S. 2015. Standard assessment of agricultural mitigation potential and livelihoods. Available: http://samples.ccafs.cgiar.org/wp-

content/uploads/2015/06/Chapter-3-Land-use-and-land-cover-change.pdf. Last accessed $29^{\text {th }}$ May 2016.

O'Connor S, Salafsky N, Salze D. 1986. Monitoring forest restoration projects in the context of an adaptive management cycle. Forest Restoration in Landscapes. p145-149.

Smith P, Davies C, Ogle S, Zanchi G, Bellarby J, Bird N, Boddey RM, McNamara NP, Powlson D, Cowie A, Noordwijk M, Davis SC, Richter DDB, Kryzanowski L, Wijk MT, Stuart J, Kirton A, Eggar D, Newton-Cross G, Adhya TK, Braimoh AK. 2012. Towards an integrated global framework to assess the impacts of land use and management change on soil carbon: current capability and future vision. Glob Chang Biol. 18:p2089-2101. doi:10.1111/j.13652486.2012.02689.x.

Vallauri D, Aronson J, Dudley N. 1986. An attempt to develop a framework for restoration planning. Forest Restoration in Landscapes. (1)p65-70. 


\section{ANNEX 1: Carbon dioxide equivalent}

A carbon dioxide equivalent is a measure used to compare the emissions from various greenhouse gases based on their global warming potentials (OECD 2001). Apart from water vapour, the main greenhouse gases in the Earth's atmosphere are carbon dioxide $\left(\mathrm{CO}_{2}\right)$, methane $\left(\mathrm{CH}_{4}\right)$, nitrous oxide $\left(\mathrm{N}_{2} \mathrm{O}\right)$ and ozone (Brander 2012). Each of the gases has different global warming potentials and resides in the atmosphere for different lengths of time (Climate Change Connection 2014). Although these greenhouse gases occur naturally in the earth's atmosphere, human activities have accelerated the concentrations of these gases resulting in increased climate change.

The most common conversion used between $\mathrm{CO}_{2}$ and $\mathrm{CO}$ is the rate of 3.7. This factor is used to convert tonnes of carbon dioxide into carbon. These conversions allow a better calculation of a radiative forcing effect that leads to global warming. The global warming potential (GWP) of a greenhouse gas indicates the amount of warming it can cause over a given period of time, normally about 100 years. Carbon dioxide has a global warming potential of 1 . Additionally, the global warming potentials of the remaining greenhouse gases listed above depict the number of times more warming they cause as compared to carbon dioxide (Brander 2012).

Table A1.1 below gives the global warming potentials of various greenhouse gases from land use change.

Table A1.1: The 'Kyoto gases' and their relevant global warming potentials

\begin{tabular}{|l|l|}
\hline Greenhouse gas & Global warming potential (GWP) \\
\hline Carbon dioxide $\left(\mathrm{CO}_{2}\right)$ & 1 \\
\hline Methane $\left(\mathrm{CH}_{4}\right)$ & 25 \\
\hline Nitrous oxide $\left(\mathrm{N}_{2} \mathrm{O}\right)$ & 298 \\
\hline
\end{tabular}

Source: IPCC 2007, Brander 2012

In this report, the carbon equivalent is used throughout, and therefore all greenhouse gases emitted are measured under carbon dioxide equivalent. 


\section{ANNEX 2: Biocarbon projects in Africa}

\begin{tabular}{|c|c|c|}
\hline Biocarbon project & Country & Web page link \\
\hline $\begin{array}{l}\text { Village-Based } \\
\text { Management of } \\
\text { Woody Savanna \& } \\
\text { Establishment of } \\
\text { Woodlots for } \\
\text { Carbon } \\
\text { Sequestration }\end{array}$ & Benin & $\begin{array}{l}\text { GEF } \\
\text { (http://www.gefonline.org/projectDetails.cfm?projID=389) } \\
\text { FAO, } 2004\end{array}$ \\
\hline $\begin{array}{l}\text { Sustainable Energy } \\
\text { Management } \\
\text { Project }\end{array}$ & Burkina Faso & $\begin{array}{l}\text { UNFCCC**(http://unfccc.int/kyoto_mechanisms/aij/activities } \\
\text { implemented_jointly/items/2005.php) }\end{array}$ \\
\hline $\begin{array}{l}\text { Humbo Assisted } \\
\text { Regeneration }\end{array}$ & Ethiopia & $\begin{array}{l}\text { WB BioCarbon Fund } \\
\text { (http://carbonfinance.org/Router.cfm?Page=Projport\&ProjID= } \\
\underline{\underline{9625} \text { ) }}\end{array}$ \\
\hline $\begin{array}{l}\text { Western Kenya } \\
\text { Integrated } \\
\text { Ecosystem } \\
\text { Management } \\
\text { Project }\end{array}$ & Kenya & $\begin{array}{l}\text { GEF } \\
\text { (http://www.gefonline.org/projectDetails.cfm?projID=1362) } \\
\text { (Mutunga and Mwangi 2006) }\end{array}$ \\
\hline $\begin{array}{l}\text { Green Belt } \\
\text { Movement }\end{array}$ & Kenya & $\begin{array}{l}\text { WB BioCarbon Fund } \\
\text { (http://carbonfinance.org/Router.cfm?Page=Projport\&ProjlD= } \\
\underline{\underline{9635} \text { ) }}\end{array}$ \\
\hline $\begin{array}{l}\text { Reforestation on } \\
\text { Degraded Land for } \\
\text { Sustainable Wood } \\
\text { Production of } \\
\text { Woodchips }\end{array}$ & Madagascar & $\begin{array}{l}\text { CDM pipeline updated by UNEP Riso Centre } \\
\text { http://cdmpipeline.org/ }\end{array}$ \\
\hline $\begin{array}{l}\text { Carbon from } \\
\text { Communities }\end{array}$ & Mali & $\begin{array}{l}\text { Virginia Tech University } \\
\text { (http://www.oired.vt.edu/resanddev/projects/carbon.htm) }\end{array}$ \\
\hline $\begin{array}{l}\text { Participatory } \\
\text { Rehabilitation of } \\
\text { Degraded Lands }\end{array}$ & $\begin{array}{l}\text { Mauritania } \\
\text { and } \\
\text { Senegal }\end{array}$ & GEF http://www.gefonline.org/projectDetails.cfm?projlD=457 \\
\hline $\begin{array}{l}\text { Nhambita } \\
\text { Community } \\
\text { Carbon Project }\end{array}$ & Mozambique & $\begin{array}{l}\text { University of Edinburgh http://www.miombo.org.uk/(Jindal } \\
\text { 2004) }\end{array}$ \\
\hline $\begin{array}{l}\text { Acacia Community } \\
\text { Plantations }\end{array}$ & Niger & $\begin{array}{l}\text { WB BioCarbonFund } \\
\text { (http://carbonfinance.org/Router.cfm?Page=Projport\&ProjlD= } \\
\underline{9634)}\end{array}$ \\
\hline $\begin{array}{l}\text { Sequestration of } \\
\text { Carbon in Soil } \\
\text { Organic Matter } \\
\text { (SOCSOM) }\end{array}$ & Senegal & $\begin{array}{l}\text { US GeologicalSurvey } \\
\text { (http://edcintl.cr.usgs.gov/carboninfosheet.html)(Tieszen et } \\
\text { al. 2004) }\end{array}$ \\
\hline
\end{tabular}




\begin{tabular}{|l|l|l|}
\hline Biocarbon project & Country & Web page link \\
\hline $\begin{array}{l}\text { The Namwasa } \\
\text { Forestation Project }\end{array}$ & Uganda & $\begin{array}{l}\text { CDM pipeline updated by UNEP } \\
\text { Riso Centre (http://cdmpipeline.org/) }\end{array}$ \\
\hline Plan Vivo Project & Uganda & $\begin{array}{l}\text { Plan Vivo } \\
\text { (www.planvivo.org) Carbon Neutral Company } \\
\text { (wttp://www.carbonneutral.com/projects/projects.asp?id=13) }\end{array}$ \\
\hline $\begin{array}{l}\text { Nile Basin } \\
\text { Reforestation }\end{array}$ & Uganda & $\begin{array}{l}\text { WB BioCarbon Fund ( } \underline{\text { http://carbonfinance.org/Router.cfm? }} \\
\text { Page=Projport\&ProjlD=9644) }\end{array}$ \\
\hline
\end{tabular}




\section{Working Paper series}

213. Vulnerability of smallholder farmers and their preferences on farming practices in Buol District, Indonesia http://dx.doi.org/10.5716/WP15724.PDF

214. Dynamics of land use/cover change and carbon emission in Buol District, Indonesia http://dx.doi.org/10.5716/WP15725.PDF

215. Gender perspective in smallholder farming practices in Lantapan, Philippines http://dx.doi.org/10.5716/WP15726.PDF

216. Vulnerability of smallholder farmers in Lantapan, Bukidnon http://dx.doi.org/10.5716/WP15727.PDF

217. Vulnerability and adaptive capacity of smallholder farmers in Ho Ho Sub-watershed, Ha Tinh Province, Vietnam http://dx.doi.org/10.5716/WP15728.PDF

218. Local knowledge on the role of trees to enhance livelihoods and ecosystem services in northern central Vietnam http://dx.doi.org/10.5716/WP15729.PDF

219. Land-use/cover change in Ho Ho Sub-watershed, Ha Tinh Province, Vietnam http://dx.doi.org/10.5716/WP15730.PDF

220. Agroforestry and forestry in Sulawesi series: evaluation of the agroforestry farmer field schools on agroforestry management in South and Southeast Sulawesi, Indonesia http://dx.doi.org/10.5716/WP16002.PDF

221. Farmer-to-farmer extension of livestock feed technologies in Rwanda: A survey of volunteer farmer trainers and organizations http://dx.doi.org/10.5716/WP16005.PDF

222. Projected climate change impact on hydrology, bioclimatic conditions, and terrestrial ecosystems in the Asian highlands http://dx.doi.org/10.5716/WP16006.PDF

223. Adoption of agroforestry and its impact on household food security among farmers in Malawi http://dx.doi.org/10.5716/WP16013.PDF

224. Agroforestry and forestry in Sulawesi series: Information channels for disseminating innovative agroforestry practices to villages in Southern Sulawesi, Indonesia http://dx.doi.org/10.5716/WP16034.PDF

225. Agroforestry and forestry in Sulawesi series: Unravelling rural migration networks. Landtenure arrangements among Bugis migrant communities in Southeast Sulawesi http://dx.doi.org/10.5716/WP16035.PDF

226. Agroforestry and forestry in Sulawesi series: Women's participation in agroforestry: more benefit or burden? A gendered analysis of Gorontalo Province http://dx.doi.org/10.5716/WP16036.PDF

227. Kajian Kelayakan dan Pengembangan Desain Teknis Rehabilitasi Pesisir di Sulawesi Tengah http://dx.doi.org/10.5716/WP16037.PDF

228. Selection of son tra clones in North West Vietnam http://dx.doi.org/10.5716/WP16038.PDF

229. Growth and fruit yield of seedlings, cuttings and grafts from selected son tra trees in Northwest Vietnam http://dx.doi.org/10.5716/WP16046.PDF

230. Gender-Focused Analysis of Poverty and Vulnerability in Yunnan, China http://dx.doi.org/10.5716/WP16071.PDF

231. Seri Agroforestri dan Kehutanan di Sulawesi: Kebutuhan Penyuluhan Agroforestri untuk Rehabilitasi Lahan di Sumba Timur, Nusa Tenggara Timur, Indonesia http://dx.doi.org/10.5716/WP16077.PDF

232. Agroforestry and Forestry in Sulawesi series: Agroforestry extension needs for land rehabilitation in East Sumba, East Nusa Tenggara, Indonesia. http://dx.doi.org/10.5716/WP16078.PDF

233. Central hypotheses for the third agroforestry paradigm within a common definition. http://dx.doi.org/10.5716/WP16079.PDF

234. Assessing smallholder farmers' interest in shade coffee trees: the farming systems of smallholder coffee producers in Gisenyi Area, Rwanda http://dx.doi.org/10.5716/WP16104.PDF

235. Review of agricultural market information systems in sub-Saharan Africa. DOI: http://dx.doi.org/10.5716/WP16110.PDF

236. Vision and road map for establishment of a protected area in Lag Badana, Lower Jubba, Somalia. DOI: http://dx.doi.org/10.5716/WP16127.PDF 
The World Agroforestry Centre is an autonomous, non-profit research organization whose vision is a rural transformation in the developing world as smallholder households increase their use of trees in agricultural landscapes to improve food security, nutrition, income, health, shelter, social cohesion, energy resources and environmental sustainability. The Centre generates science-based knowledge about the diverse roles that trees play in agricultural landscapes, and uses its research to advance policies and practices, and their implementation that benefit the poor and the environment. It aims to ensure that all this is achieved by enhancing the quality of its science work, increasing operational efficiency, building and maintaining strong partnerships, accelerating the use and impact of its research, and promoting greater cohesion, interdependence and alignment within the organization.

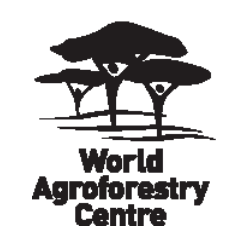

United Nations Avenue, Gigiri • PO Box 30677 • Nairobi, 00100 • Kenya Telephone: +254207224000 or via USA +1 6508336645 Fax: +254207224001 or via USA +1 6508336646 Email: worldagroforestry@cgiar.org •www.worldagroforestry.org 